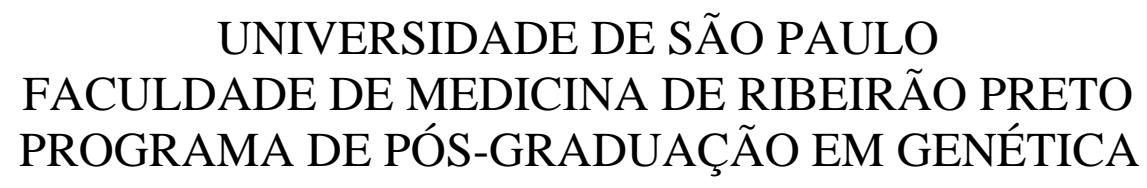

\title{
“Caracterização genética de uma população do gado crioulo Pé-duro do Piauí, através de marcadores microssatélites.”
}

\author{
Ana Paula Ferreira de Oliveira
}

\begin{abstract}
Tese apresentada à Faculdade de Medicina de Ribeirão Preto, da Universidade de São Paulo, como parte dos pré-requisitos para obtenção do título de Doutor em Ciências.
\end{abstract}

Orientadora: Prof ${ }^{\mathrm{a}}$. Dr ${ }^{\mathrm{a}}$. Eucleia Primo Betioli Contel 
FICHA CATALOGRÁFICA

Ana Paula Ferreira de Oliveira

Caracterização genética de uma população do gado crioulo Pé-duro do Piauí, através de marcadores microssatélites.

Ribeirão Preto, 2008

112 p. : il. ; 30cm

Tese de Doutorado - Programa de Pós-Graduação em Genética. Área de concentração: Genética - Faculdade de Medicina de Ribeirão Preto/USP

Orientadora: Eucleia Primo Betioli Contel

1. Pé-duro 2. Curraleiro 3. Bos taurus 4. Microssatélites 5. Conservação Genética. 


\section{AGRADECIMENTOS}

À Professora Eucleia P. B. Contel pela amizade, paciência, estímulo, confiança e segura orientação na elaboração deste trabalho.

À Dra.Maria Aparecida C. Lara, do Instituto de Zootecnia, Nova Odessa, pela concessão dos iniciadores utilizados neste trabalho.

Ao Dr. Marcos Miretti, responsável pela coleta das amostras do Pé-duro do Piauí.

À Elisabete Barreto Beira, companheira de laboratório, pela assistência técnica.

Ao Mestre José Herculano de Carvalho, Pesquisador da EMBRAPA MeioNorte, pelas valiosas informações sobre o gado Pé-duro.

Aos amigos do laboratório Dra. Cláudia E. Vieira Wiezel e Dr. Eddy José Francisco de Oliveira, pela amizade e pelas valiosas sugestões no trabalho.

À Maria do Carmo e Ana Lúcia, pela amizade e pelas dicas e sugestões da prática de laboratório; sem elas esse trabalho ainda não teria sido completado.

A todos os demais amigos do Bloco B presentes nesses quatros anos, Daniela, Edna, Eliana, Geusa, as duas Julianas, Marcela, Marcelo, Rosana, Ronai, Yara e Prof. Aguinaldo, pela amizade e pelos momentos de descontração e divertimento.

Ao Conselho Nacional de Desenvolvimento Científico e Tecnológico pelo suporte financeiro e pela bolsa concedida para o desenvolvimento do trabalho.

À Fundação de Apoio ao Ensino, Pesquisa e Assistência (FAEPA) do HCFMRP, pelos auxílios concedidos. 
RESUMO

i

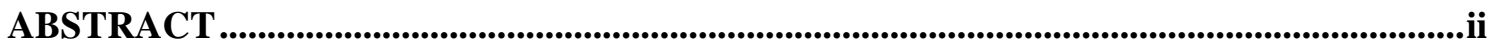

I. INTRODUÇÃO .................................................................................................................................... 1

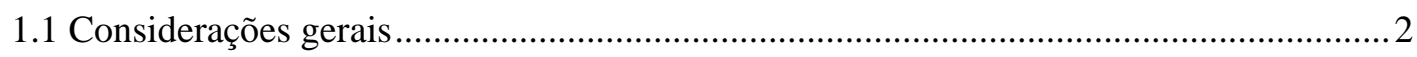

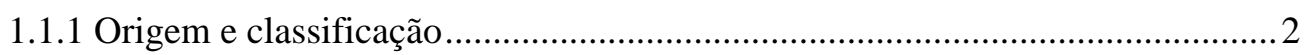

1.1.2 Domesticação e distribuição ............................................................................... 4

1.2 Introdução dos bovinos na América do Sul ..................................................................... 6

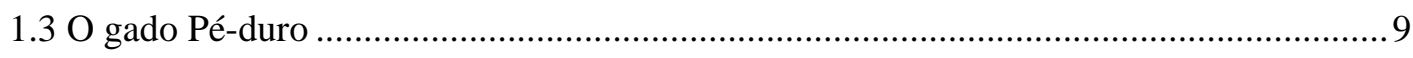

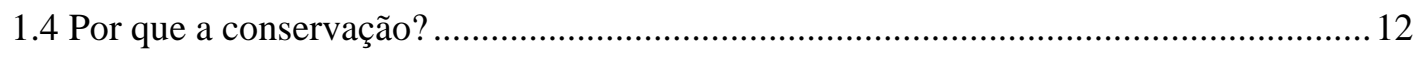

1.5 Marcadores moleculares microssatélites na análise de populações ...............................14

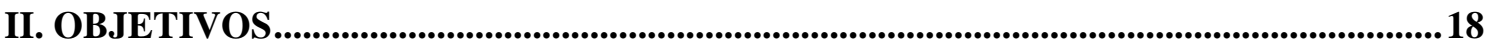

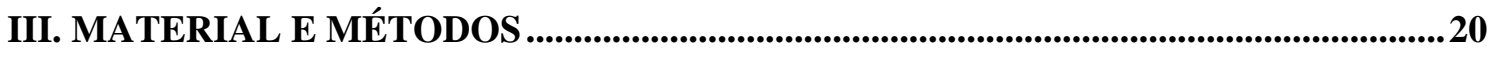

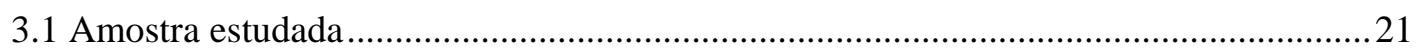

3.2 Marcadores moleculares microssatélites investigados ................................................21

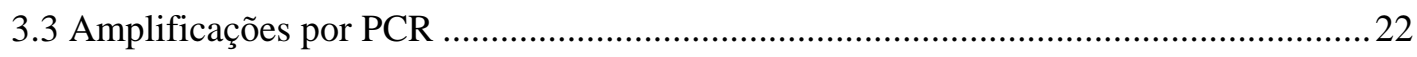

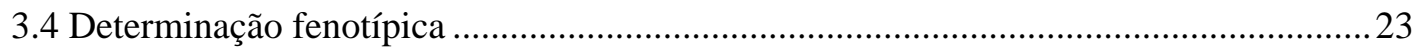

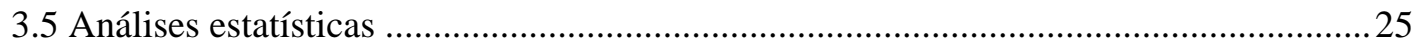

3.5.1 Estimativas das freqüências alélicas e genotípicas ...........................................26

3.5.2 Heterozigose intraloco observada, esperada e conteúdo de informação de

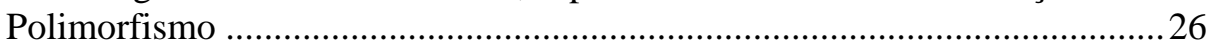

3.5.3 Aderência ao equilíbrio de Hardy-Weinberg..................................................2 27

3.5.4 Diversidade gênica ...................................................................................... 28

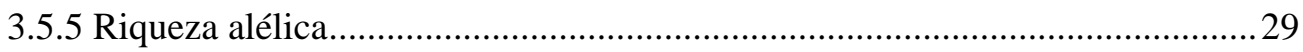

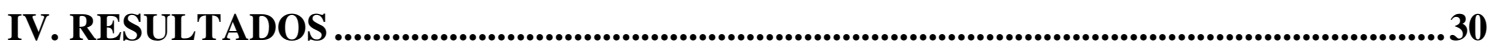

4.1 Diversidade genética dentro da população Pé-duro ......................................................31

4.2 Diversidade genética comparativa entre a população Pé-duro e populações nativas

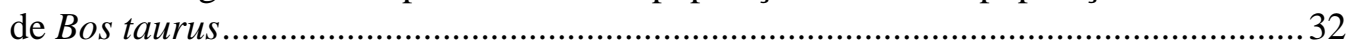

4.2.1 Diversidade gênica ......................................................................................... 32

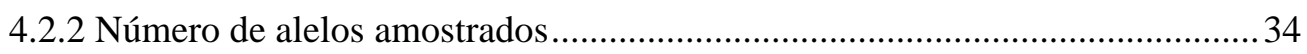


4.2.3 Heterozigose observada .................................................................................. 34

4.2.4 Coeficiente de endogamia (Fis) .................................................................... 35

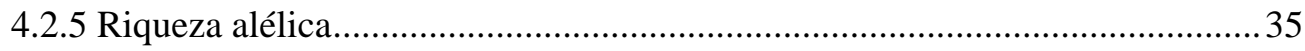

4.3 Diversidade genética comparativa entre a população Pé-duro e populações nativas

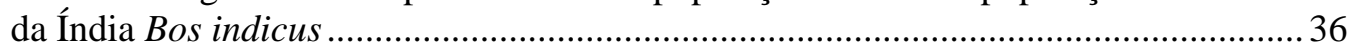

4.4 Diversidade genética comparativa entre Pé-duro e raças comerciais de Bos taurus

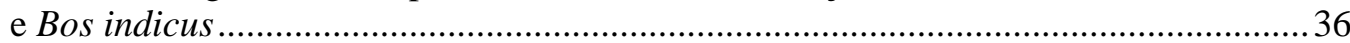

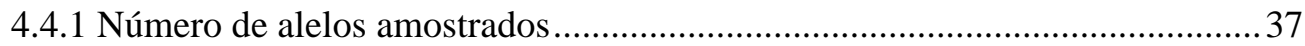

4.4.2 Conteúdo de informação de polimorfismo ………………………………........ 37

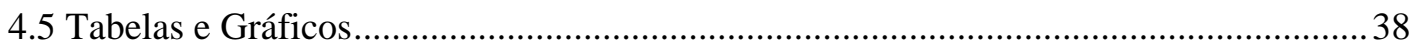

V. DISCUSSÃO

5.1 Diversidade genética dentro da população Pé-duro .......................................................65

5.2 Diversidade genética comparativa entre Pé-duro e outras populações .............................68

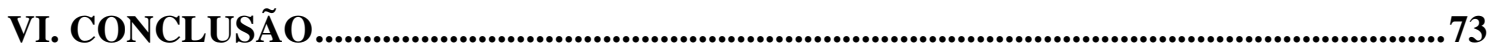

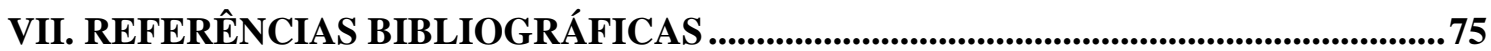

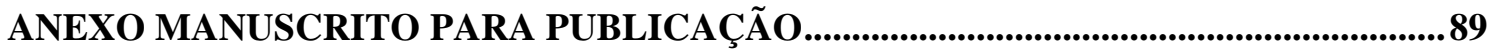




\section{RESUMO}

Oliveira, A. P. F. Caracterização genética de uma população do gado crioulo Pé-duro do Piauí, através de marcadores microssatélites. 2008. 112p. Tese de Doutorado - Faculdade de Medicina de Ribeirão Preto, Universidade de São Paulo.

A raça crioula Pé-duro do Piauí (Bos taurus) é extremamente bem adaptada às condições ambientais desfavoráveis da zona semi-árida do Nordeste Brasileiro e está em risco de extinção. Neste trabalho foi caracterizada geneticamente, por microssatélites, uma amostra $(n=126)$ originária da Fazenda Experimental Octavio Domingues, da Embrapa Meio-Norte, no município de São João do Piauí. A variabilidade genética foi estimada através de freqüências gênicas, diversidade gênica, heterozigose esperada e observada, riqueza alélica, valor do Pic (conteúdo de informação de polimorfismo), coeficiente de endogamia e verificação do equilíbrio de Hardy-Weinberg. Os locos analisados foram SPS115, BM1824, BM2113, BMS4049, TGLA122, ETH225, ETH10, INRA23, UWCA46 e BMS348, identificando-se um total de 101 alelos. A diversidade gênica média foi de 75,6\%, com valores extremos verificados nos locos TGLA122 (91,3\%) e BMS4049 (45,4\%). O valor médio da heterozigose esperada foi 75,5\%, observada 60,0\%, e Pic 72,3\%. O coeficiente de endogamia Fis foi estatisticamente significativo (Fis=0,206; $\mathrm{P}<0,01$ ). Foram observados também desvios do equilíbrio de Hardy-Weinberg em nove dos dez locos analisados. A partir dos dados obtidos foi possível observar que ainda existe diversidade genética nesta população, porém os desvios do equilíbrio, o valor significativo do Fis, e a heterozigose observada menor em todos os locos em relação à esperada, demonstraram a ocorrência de cruzamentos endogâmicos resultando em alto nível de homozigose nesta população.

Palavras-chave: Pé-duro, Curraleiro, Bos taurus, Microssatélites, Conservação Genética. 


\begin{abstract}
Oliveira, A. P. F. Genetic characterization of a creole cattle population Péduro from Piauí, based on microsatellite loci. 2008. 112p. Doctoral Thesis Faculdade de Medicina de Ribeirão Preto, Universidade de São Paulo.

The Pé-duro creole breed is well adapted to the unfavorable environmental conditions of the semiarid zone of Northeastern Brazil and it is in extinction danger. In this work we tried to characterize genetically a sample $(n=126)$ collected at the Embrapa Meio-Norte, located in São João do Piauí city. We examined heterozygosity, polymorphism information content (Pic), allelic frequency and genetic diversity, allelic richness, inbreeding coefficient and Hardy-Weinberg equilibrium. Ten loci were used SPS115, BM1824, BM2113, BMS4049, TGLA122, ETH225, ETH10, INRA23, UWCA46 and BMS348 - and a total of 101 alleles were identified. The largest genetic diversity was verified in the locus TGLA122 (91,3\%), and the smallest in the locus BMS4049 (45,4\%). The mean expected heterozygosity was $75,5 \%$, the mean observed heterozygosity was $60,0 \%$, and the mean Pic value was estimated as $72,3 \%$. We also observed a significant inbreeding coefficient (Fis) for this population (Fis=0,206 $\mathrm{P}<0,01$ ) and deviations from the Hardy-Weinberg equilibrium in nine of the ten analyzed loci. Considering the obtained data it was possible to infer that genetic diversity still exists in this population, however the deviations from Hardy-Weinberg equilibrium, significant inbreeding coefficient, and the smaller observed heterozygosity in all of the loci showed the occurrence of high degree of inbreeding in this population.
\end{abstract}

Keywords: Pé-duro, Curraleiro, Bos taurus, Microsatellites, Genetic Conservation. 


\section{INTRODUÇÃO}




\subsection{Considerações gerais}

\subsubsection{Origem e classificação}

A origem dos atuais bovinos domésticos não é consensual e as teorias propostas podem ser sintetizadas em monofilética e polifilética (Athanassof, 1957).

A teoria monofilética está baseada na descendência direta de um ancestral comum, o extinto boi selvagem conhecido como Auroque ou Uro e cientificamente como Bos primigenius, espécie provavelmente surgida na Índia (Mariante e Cavalcante, 2006) no fim do Pleistoceno, tendo sido extinta em 1627 quando o último exemplar foi abatido em uma reserva para caça próxima a Varsóvia, Polônia (Felius, 1985).

A época denominada Pleistoceno (do período Quaternário, da era Cenozóica) abrange de 1,6 milhão até 200 mil anos atrás e foi uma época caracterizada por grandes glaciações e por uma série de oscilações climáticas abruptas em todo o globo; nessas oscilações geleiras avançavam do norte para o sul durante os períodos mais frios, retraindo-se durante os períodos interglaciais mais quentes. Como resultado, as populações de plantas e animais foram repetidamente isoladas e novamente reunidas. Geneticamente, o isolamento seguido de nova reunião das populações causou rápida especiação (Pough et al, 1993).

As glaciações da época impediam a expansão do Auroque para a Europa, mas a espécie ampliou seus limites de distribuição até o continente europeu durante os períodos interglaciais. Foi somente após o Pleistoceno, com o retraimento das geleiras, que os bovinos expandiram-se do oeste para o leste da Ásia, até a China, e a oeste em direção ao Oriente Médio, norte da África e Europa. Enquanto a espécie se expandia, ela também se diferenciava. A ciência já reconheceu uma grande variedade de subtipos com base no tamanho do crânio, formato do chifre e outras evidências fornecidas pelos 
fósseis. O número exato de subtipos é ainda motivo de discórdia, mas dois grandes grupos podem ser identificados, grupos que são algumas vezes considerados como subespécies distintas: Bos primigenius primigenius, que deu origem ao gado europeu, sem cupim - Bos taurus - e Bos primigenius namadicus, das regiões tropicais, forma asiática que deu origem ao gado de cupim, ou zebu - Bos indicus. Esqueletos reconstruídos com base nos fósseis revelam que os Auroques eram animais grandes, fortes e resistentes (Felius, 1985).

A teoria polifilética abarca um conjunto de hipóteses confluentes em duas grandes tendências, a difilética e a polifilética propriamente dita. A primeira defende que os bovinos domésticos descendem, paralelamente, de duas formas pré-históricas, o Bos primigenius e o Bos brachycerus. A segunda defende a evolução da espécie a partir de várias formas primitivas, incluindo Bos primigenius, Bos brachycerus, Bos frontosus e Bos aqueratus (Athanassof, 1957).

A classificação taxonômica dos bovinos segue a seguinte hierarquia:

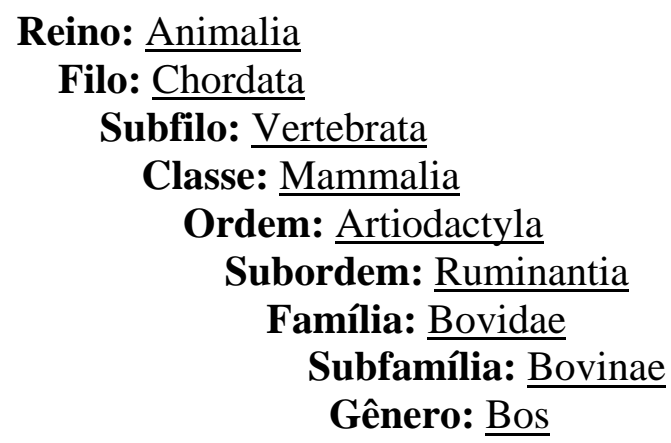

Na família Bovidae (128 espécies) estão incluídos os bovinos e os antílopes. No primeiro grupo estão os bois, búfalos, o bisão e o iaque da Ásia Central; no segundo, estão a gazela, os caprinos e os ovinos. 


\subsubsection{Domesticação e distribuição}

Não se sabe exatamente quando e porquê os bovinos foram domesticados, apesar da evidência arqueológica dada por numerosas descobertas de ossos bovinos próximo a ruínas de antigos povoamentos ao longo da costa leste do Mediterrâneo e regiões adjacentes (Felius, 1985). Os dados fósseis mostram que a domesticação dos bovinos (aproximadamente 6.000 a.C.) ocorreu com a domesticação do cão, o primeiro animal domesticado - por volta de 10.000 a.C. - e outros animais de abate, entre eles o carneiro (7.000 a.C.) e o porco (6.000 a.C.) (Mariante e Cavalcante, 2006). Fragmentos de esqueletos de pequenos bois domesticados, que datam de 6.500 a.C., foram encontrados na Turquia e no Oriente Médio (Felius, 1985).

A domesticação de animais não surgiu diretamente da caça mas sim com as sociedades de agricultores no período Neolítico (Mariante e Cavalcante, 2006). Os primeiros centros agrícolas datam de 8.000 a 5.000 a.C. e estavam situados ao longo da costa mediterrânea. Por volta do ano 6.000 a.C. a grande revolução da agricultura penetrou o rio Nilo e as terras férteis do norte da África, Europa Central e oeste da Ásia. Enquanto a agricultura avançava em novos territórios, a domesticação dos bovinos seguia pelos mesmos caminhos (Felius, 1985). Atribui-se sobretudo aos celtas (especialmente nos séculos 5 e 4 a.C.) e aos romanos o deslocamento dos bovinos na direção oeste da Europa e, portanto, para a Península Ibérica (Mariante e Cavalcante, 2006). As migrações humanas, no início da Era Cristã, também promoveram uma significativa distribuição dos animais domésticos.

Tanto a domesticação quanto a agricultura são idéias práticas. Juntas, elas permitiram ao homem estabelecer reservas confiáveis de alimento e abandonar a vida nômade de caçador e coletor. Elas foram essenciais para o surgimento de povoamentos permanentes. Nessa longa trajetória da transformação das sociedades humanas e sua 
dispersão através dos continentes, o convívio com os animais significou alimento, agasalho, transporte, trabalho, defesa e companhia, entre outros, conferindo uma transformação geral da natureza promovida pelo homem para servir aos seus fins. Além disso, alguns animais eram considerados símbolo da fertilidade e usados em rituais e práticas religiosas; artefatos ligados à adoração dos touros foram encontrados em muitas áreas onde os bovinos foram inicialmente domesticados. O simbolismo da fertilidade do touro desse período continuou nas culturas antigas do Oriente Médio, norte da África e Europa (Felius, 1985).

O longo processo de domesticação tornou possível o homem selecionar os rebanhos e desenvolver raças resistentes e adequadas às suas necessidades. Esse processo lento e profundo levou à modificação das espécies no que diz respeito não somente ao comportamento, mas também à morfologia, fisiologia e características genéticas (Mariante e Cavalcante, 2006). Qualquer que tenha sido o motivo da domesticação dos bovinos - pragmático, místico ou uma combinação dos dois - a espécie passou por mudanças físicas notáveis sob o cuidado do homem. O tamanho do animal diminuiu e o crânio mudou de formato. Os chifres ficaram menores e mais finos ou foram eliminados, e a pelagem adquiriu novos padrões e tonalidades. Os bovinos domesticados perderam tão rapidamente o estado selvagem que aqueles representados em pinturas egípcias de 4.500 anos atrás impressionariam a maioria dos fazendeiros de hoje pelo porte pequeno.

Como essas mudanças ocorreram, não é mistério algum. Características recessivas que raramente se expressam em grandes populações selvagens de bovinos (ou qualquer outro animal) se manifestam mais facilmente em pequenas populações de rebanhos criados pelo homem. A falta de chifres ou coloração malhada são características que podem ser fatais para um indivíduo solto na natureza, pois prejudica 
sua defesa ou o torna mais visível aos predadores, mas não têm relação com a luta de um animal doméstico pela sobrevivência. Muito pelo contrário. Tais características podem muito bem valorizar um animal para seu dono, que poderá tomar medidas para garantir sua continuidade em gerações futuras. Um touro malhado nascido em um rebanho inteiramente preto muito provavelmente irá produzir mais touros do seu tipo se for usado como reprodutor; um animal sem chifres pode ser usado para formar rebanhos sem chifres.

O princípio utilizado pelo homem no longo processo de domesticação pode não ter sido totalmente confiável, mas com ele o homem exerceu uma "pressão de seleção” que era suficientemente poderosa para criar o gado desejado e assim foi por muitos séculos (Felius, 1985). Considerando o contexto econômico das sociedades humanas, os bovinos tiveram um papel central na sua evolução por ser a mais importante espécie de animal doméstico (Loftus et al, 1994).

\subsection{Introdução dos bovinos na América do Sul}

A introdução do gado na América aconteceu nos primeiros 100 anos da colonização (Rabasa, 1993). O gado sul-americano originou-se a partir de duas correntes colonizadoras: o desembarcado no Caribe e o desembarcado no litoral brasileiro.

O gado desembarcado no Caribe, com ascendência espanhola e portuguesa, desceu desde o Panamá e a Colômbia até o Peru, o Chile e a Bolívia. Da Bolívia entraram no Noroeste Argentino em 1549 e no Chile, nos anos de 1552 a 1557. De Santa Cruz de la Sierra (Bolívia) partiram, em 1569, um número importante de cabeças com destino a Assunção, no Paraguai. A partir de Assunção os bovinos povoaram a região litorânea da Argentina e do Brasil (Miretti, 2002; Miretti et al, 2004). 
Estas populações originais formaram as denominadas raças nativas da América do Sul, também chamadas de raças crioulas, submetidas exclusivamente ao processo de seleção natural por mais de 400 anos, em pequenas populações e numa grande variedade de ambientes, desde as montanhas andinas a ambientes tropicais úmidos - muitos ambientes totalmente adversos - o que levou a uma ampla diversidade de raças ajustadas a diferentes nichos ecológicos. No continente sul-americano atualmente encontram-se várias raças nativas, como o gado crioulo Argentino, o crioulo do Uruguai (Armstrong et al, 2006) e o crioulo da Colômbia (Sastre, 2003; Barrera et al, 2006).

No Brasil a grande introdução do rebanho bovino iniciou-se na época da colonização pelos portugueses no século XVI, no governo de Tomé de Souza, com o gado trazido da Península Ibérica (Britto, 1998). O primeiro rebanho bovino desembarcou em São Vicente, em 1534, por ordem de D. Ana Pimentel, procuradora do donatário da Capitania, Martim Afonso de Souza (Mariante e Cavalcante, 2006).

O gado bovino português foi introduzido em três épocas e locais diferentes (Camargo, 1986, apud Miretti, 2002): Recife - 1534-1554, São Vicente - 1534-1538 e Salvador em 1550 (Giberti, 1974, apud Miretti, 2002). Estes três núcleos - São Paulo ao sul, Bahia ao centro e Pernambuco ao norte - se constituíram basicamente nas zonas importadoras de gado de origem portuguesa que se reproduzia livremente, sem a interferência do homem (Mariante e Cavalcante, 2006). Os animais introduzidos em Pernambuco eram originários das Ilhas Madeira e os de São Paulo e Bahia, de Cabo Verde. Estes rebanhos poderiam ter sido portadores de genes zebuínos africanos, ou têlos recebido após a chegada ao continente (Primo, 1986). Quase todas as raças crioulas locais tiveram como ancestrais raças bovinas de Portugal, como a Barrosã, a Mirandesa, 
a Minhota e a Alentejana; muitas dessas raças bovinas do descobrimento continuam a ser criadas na Península Ibérica (Mariante e Cavalcante, 2006).

De São Vicente partiram grupos de bovinos levados pelos colonizadores para os campos sulinos, para Goiás, para o Vale do São Francisco, chegando até os campos do Piauí e do Ceará. Por outro lado, os bovinos que chegaram aos portos da Bahia emigraram para o sertão nordestino, norte de Minas e oeste da Bahia. Dessa forma, as raças importadas ibéricas difundiram-se, fixaram-se em zonas distintas e deram início ao povoamento dos campos naturais do Brasil. Após muitos anos de seleção natural, estas populações adaptaram-se ao ambiente particular de cada região, ao clima tropical, desenvolveram características que as permitiram sobreviver inclusive a uma oferta pobre de alimentos e sua base genética contribuiu para a formação dos grandes rebanhos nacionais (Santiago, 1975, 1985; Camargo, 1990, apud Britto, 1998; Almeida et al, 2000; Spritze et al, 2003). Diversos exemplares do gado crioulo foram posteriormente transferidos para várias regiões do Brasil, onde foram cruzados com rebanhos trazidos pelos colonizadores lá existentes, formando várias raças (Spritze et al, 2003); entre elas destacam-se a Pantaneira, na região do Pantanal Mato-grossense, a Crioula Lajeana, na região Sul (Planalto Catarinense) e a Junqueira, na região norte de São Paulo e no sul de Minas Gerais (Mariante e Cavalcante, 2006). Por exemplo, supõe-se que muitos animais tenham se extraviado de tropas ao longo do caminho - no Planalto Catarinense embrenharam-se nas matas e, com o tempo, passaram a formar rebanhos nos campos de Lages. Com a colonização do Planalto Catarinense, os agricultores trouxeram o gado Franqueiro que, provavelmente, cruzou com os bovinos ali existentes, originando o gado conhecido como Crioulo Lageano (Spritze et al, 2003).

Como as raças brasileiras não são nativas, Domingues (1961) sugere o uso dos termos “raças nativas naturalizadas” e "raças nativas selecionadas”, de acordo com o 
tipo de seleção a que estas foram submetidas. As raças nativas naturalizadas se caracterizam por serem um produto da influência do ambiente sob determinados caracteres, ou seja, são resultantes de um processo de seleção natural no qual a intervenção do homem não parece ter agido. São exemplos as raças Pé-duro ou Curraleiro, Pantaneira, Patuá e Crioulo Lageano, entre outras. As raças naturalizadas selecionadas são aquelas que foram submetidas a um processo de melhoramento genético, graças à intervenção humana através da seleção artificial com o objetivo de melhorar a capacidade reprodutiva e o valor econômico. Neste grupo estão o gado Caracu e o Mocho Nacional. As raças crioulas criadas em nosso ambiente provavelmente mantêm um pool gênico que lhes confere um maior valor adaptativo quando comparadas às raças zebuínas e mestiças especializadas para corte e leite.

Com a importação - principalmente no início do século XX - das raças exóticas zebuínas Gir, Guzerá e Nelore, as raças nativas naturalizadas sofreram uma enorme redução, tanto no efetivo populacional quanto na diversidade genética. Elas foram substituídas gradualmente por raças de interesse econômico através do cruzamento indiscriminado com o gado zebu, o que tem contribuído para sua provável extinção (Lara, 1998). Mas a persistência de alguns criadores impediu que a extinção das raças crioulas se desse por completo (Mariante e Cavalcante, 2006).

\subsection{O gado Pé-duro}

O gado crioulo é o principal responsável pela formação do bovino comumente denominado Pé-duro ou Curraleiro. A denominação Pé-duro é comum em alguns estados como Piauí e Maranhão; em outros, como Goiás e Tocantins, esta raça é conhecida como Curraleira. A raça é descendente dos bovinos trazidos pelos portugueses no período colonial. Segundo Athanassof (1957) ela seria descendente 
direta da raça Mirandesa, encontrada na região de Trás-os-Montes, Portugal; entretanto, parece pouco provável que apenas bovinos Mirandeses tenham dado origem ao gado Pé-duro, mas sim um conjunto de reses de diferentes grupos genéticos, naquela época ainda não estabelecidos como raça (Carvalho et al, 2001).

O Pé-duro foi introduzido no Piauí em 1674, a partir do Rio São Francisco, por Domingos Afonso Manfrense, um pioneiro no desbravamento deste estado. Multiplicou-se no norte e especialmente no nordeste do país - incluindo o vale do Rio São Francisco - de onde desceu para os campos e cerrados de Minas e Goiás (Santiago, 1975, 1985, apud Britto, 1998). Na história do Piaú colonial, a política econômica era toda baseada no comércio deste gado, que se consolidara no mercado nacional. Entretanto, em 1711, Domingos Afonso Manfrense faleceu deixando em seu testamento todas as fazendas de gado Curraleiro aos padres Jesuítas. Após várias administrações, em 1760 a pecuária piauiense entrou em decadência devido ao confisco pelo estado dessas fazendas; os jesuítas foram perseguidos e expulsos pelo governador que dividiu as terras em três inspeções, nomeando administradores para cada uma delas. Por volta de 1811 havia apenas 35 fazendas com gado Pé-duro. O Piauí estava encontrando séria concorrência no mercado de gado com outros estados como Ceará e Maranhão. Além disso, todos os locais e terras servidos com chuvas abundantes haviam sido destinados à cultura de cana-de-açúcar e o gado Curraleiro passou a ser criado somente em regiões de pluviosidade instável (Britto, 1998).

Esse é um resumo da história do aparecimento da raça Pé-duro, formada por animais extremamente rústicos, de menor peso, que ao longo dos séculos adaptaram-se gradualmente à seca, ao calor, a pastagens de qualidade inferior, à alimentação escassa, sem cuidados sanitários - incluindo parasitas - e a outros fatores adversos existentes nos 70\% da área da região Nordeste, a Caatinga e o Sertão (Britto, 1998; Carvalho, 
2002; Mariante e Cavalcante, 2006). O porte menor dos bovinos Curraleiro em relação a outros bovinos se deve, portanto, à ação da seleção natural em condições precárias, sobretudo nutricionais, no ambiente da região nordestina (Trovo, 1985, apud Britto, 1998). De acordo com Carvalho (2002) o porte pequeno reduziu seu valor econômico. Mas, apesar de magro, o gado Pé-duro se beneficia do ar seco - que impede a proliferação de carrapatos e bernes - fazendo com que o couro, embora riscado pela vegetação da caatinga, não apresente perfurações (Mariante e Cavalcante, 2006).

Com a introdução das raças zebuínas de maior tamanho, os reprodutores da raça Pé-duro passaram a ser castrados sistematicamente e substituídos por touros zebus. Esse tipo de cruzamento absorvente quase extinguiu a raça (Carvalho, 1985). Visando contribuir para a manutenção deste valioso patrimônio genético, o atual Centro de Pesquisa Agropecuária do Meio-Norte (Embrapa Meio-Norte) estabeleceu em 1983, no município de São João do Piauí, um rebanho para a conservação da raça Pé-duro. Em 2001, o núcleo estava formado por 335 bovinos (Carvalho et al, 2001) e em 2004, este número era de aproximadamente 350 animais (Carvalho, comunicação pessoal, 2007). Embora não existam estatísticas confiáveis sobre a atual população do gado Pé-duro ou Curraleiro, sabe-se que ele é criado em pequeno número, principalmente em regiões isoladas dos estados do Piauí, Maranhão, Tocantins e Goiás. Sua população total é muito reduzida e poderá ser ainda mais, se não forem tomadas providências efetivas para sua conservação (Carvalho et al, 2001).

Segundo levantamento do Ministério da Agricultura, existem no Nordeste cerca de 154.117.00 hectares de superfície e, desses, 30,97\% - 47.725.408 hectares do território regional - correspondem a terras do grupo 5 de aptidão agrícola.

O Sistema de Avaliação da Aptidão Agrícola das Terras é uma classificação para utilização do solo, tais como lavouras, pastagem plantada, silvicultura e/ou 
pastagem natural e preservação da flora e fauna. Para diagnosticar o comportamento das terras diante da adoção de práticas agrícolas, são considerados três níveis de manejo: primitivo, pouco desenvolvido e desenvolvido, indicados pelas letras A, B, e C, respectivamente, com seus grupos e subgrupos de aptidão agrícola de classificação de 1 a 9 (Ramalho Filho e Beek, 1995). Especificamente no estado do Piaú 40,76\% das terras correspondem ao grupo 5, somando um total de 25.093.400 hectares. Essas terras apresentam um sistema de manejo de nível baixo ou médio de insumos e não são recomendadas para uso como lavouras ou pastagens cultivadas e sim como pastagens naturais ou para preservação ambiental. Assim, a criação de espécies ou raças adaptadas como os bovinos da raça Pé-duro constituem uma opção racional para o uso sustentável das terras deste grupo de aptidão agrícola e utilização desta vasta superfície (Carvalho, 2002).

\subsection{Por que a conservação?}

A criação de raças tem uma forte ligação com a nossa cultura. Durante séculos as raças têm sido formadas por seleção natural e artificial, de acordo com as condições ambientais e as necessidades humanas (Maudet et al, 2002). Entretanto, os sistemas comerciais de produção convergem para padronizar o uso de umas poucas raças ou linhagens, que atendam principalmente a critérios de elevada produtividade. Nesse cenário, o valioso patrimônio genético representado por raças bovinas crioulas tende a desaparecer irremediavelmente Devemos considerar essa tendência como inevitável, vinculada ao "progresso”, ou devemos tomar providências para impedi-la? (Carvalho, 2000).

Os estudos na área da genética da conservação - em sua maioria - são realizados com o objetivo de lançar estratégias e prioridades na conservação da 
biodiversidade, incluindo nas prioridades espécies carismáticas (Muñoz, 2007) que atraem a atenção do público e dos órgãos financiadores (Solé-Cava, 2004). No entanto, os processos de redução populacional que podem chegar até o risco de extinção aconteceram e continuam acontecendo com muitos animais não carismáticos e "menos felizes” na sua atração da atenção pública, como é o caso das raças crioulas de bovinos. É fundamental, portanto, que as políticas de conservação das espécies levem em consideração a variabilidade gênica como um todo nos estudos da biodiversidade molecular na evolução das espécies, sejam elas carismáticas ou não (Solé-Cava, 2004).

A conservação do gado crioulo assim como de outras espécies domésticas, é reconhecidamente importante para a biodiversidade, pois os seus genes e as suas combinações podem ser de grande utilidade no futuro (Hall e Bradley, 1995, apud BejaPereira et al, 2003), por exemplo, para solucionar problemas criados pela perda excessiva de diversidade genética (Carvalho, 2000). Segundo a FAO - Food and Agriculture Organization - (1984), sua conservação justifica-se por inúmeros motivos entre os quais: 1- a demanda por produtos e mudanças da produção animal não podem ser previstas; 2- raças nativas, seus recursos genéticos e as características de produção animal merecem ser conservados do mesmo modo que monumentos históricos, pois são identificados com a história e as particularidades de uma determinada região; 3- essas raças são - sob certos aspectos - curiosidades regionais e, portanto, apresentam potencial para o turismo; 4- raças nativas de baixa produtividade mantidas em ambientes adversos podem ser competitivas em relação às raças produtivas no sentido que, embora estas últimas apresentem elevado potencial de produção, são mais exigentes quanto ao manejo e à alimentação. É oportuno esclarecer que a conservação e uso de recursos genéticos como do gado Pé-duro, não é um antagonismo à criação e 
manutenção de raças bovinas melhoradas. Essas ações complementam-se (Carvalho, 2000; Corrêa, 2002, apud Carvalho, 2002).

A conservação dos recursos genéticos animais é realizada no Brasil por centros de pesquisa como a Embrapa e Universidades, e seus objetivos principais são: 1- identificar e caracterizar núcleos de conservação, estabelecendo os centros de origem, a diversidade e a variabilidade genética dos grupos ameaçados de extinção; 2- conservar in situ e ex situ o material genético; 3- caracterizar geneticamente as raças; 4- ampliar nos diversos segmentos da sociedade a conscientização da importância da conservação dos recursos genéticos animais (Mariante e Cavalcante, 2006).

Considerando todas as etapas do processo de conservação dos recursos genéticos animais, o presente trabalho preenche aquela que se refere à caracterização genética da raça nativa brasileira Pé-duro, ameaçada de extinção, e vem acrescentar conhecimento sobre sua diversidade e variabilidade genética. Considerando também as recomendações da FAO (1984) já mencionadas, a conservação do gado bovino Pé-duro do Nordeste é importante não somente sob o ponto de vista científico, mas cultural, histórico e também econômico, pois esses animais constituem uma base genética para uma pecuária produtiva em ambientes desfavoráveis. Em síntese, a criação desta raça comercialmente ou não - significa a conservação de um patrimônio genético que por mais de 400 anos ajudou a escrever a história do Brasil, além de poder vir e ser fundamental para a agricultura futura (Britto, 1998).

\subsection{Marcadores moleculares microssatélites na análise de populações}

O estudo das estruturas populacionais através de técnicas moleculares talvez seja a parte mais importante da genética da conservação e tem sido útil tanto para o 
conhecimento de populações exploradas comercialmente, como para espécies ameaçadas de extinção (Solé-Cava, 2004).

Vários aspectos são úteis para a caracterização de uma população o que inclui traços fenotípicos, reprodução, distribuição geográfica, origem, habitat etc. A caracterização genética através de marcadores moleculares - permitindo a avaliação da variabilidade genética - é um aspecto adicional importante para se estabelecer estratégias e programas de conservação genética das mesmas (Vasconcellos et al, 2003).

Os microssatélites - ou repetições curtas em tandem (STRs, short tandem repeats) - são marcadores moleculares de relativa abundância no genoma, apresentam alto grau de polimorfismo, e se constituem numa excelente ferramenta para caracterização genética das populações (Almeida et al, 2000).

Esses marcadores tornaram-se rapidamente os preferidos para estudos de conservação dos recursos genéticos animais (Mariante e Cavalcante, 2006) pois possuem características apropriadas para uso em projetos envolvendo o conhecimento da estrutura populacional (MacHugh et al, 1997; 1998). Têm sido também amplamente usados em estudos de populações e/ou espécies e suas relações evolutivas (Ritz et al, 2000).

Foram muito empregados para estudar a domesticação bovina, os padrões de migração (Loftus et al, 1994), para caracterizar a estrutura das populações de gado (MacHugh et al, 1997; 1998) e também para avaliar similaridades genéticas entre e dentro de raças (Ciampolini et al, 1995). De acordo com Barendse et al (1997), Kappes et al (1997) e Peelman et al (1998) existem mais de mil microssatélites disponíveis para a realização destes estudos.

Segundo Kantanen et al (2000) eles também são importantes para tomada de decisões em programas de conservação de raças, as quais possuem uma história 
evolutiva que tem muito valor para a manutenção da sua diversidade genética (Haal e Bradley, 1995, apud Kantanen et al, 2000; Ciampolini et al, 1995).

De acordo com a FAO (1995; 2004) são os marcadores preferenciais para caracterização das raças e para projetos de conservação numa escala internacional, como o Programa Integrado de Manejo dos Recursos Genéticos. Através do projeto intitulado Measurement of Domestic Animal Diversity (MoDAD) (http://www.fao.org/dad_is) a FAO e a International Society of Animal Genetics (ISAG), em 1995, formaram um grupo de consultores que elaboraram diretrizes e recomendações técnicas para a avaliação da diversidade genética. Foi elaborada uma lista de trinta locos de microssatélites selecionados para estudos de diversidade genética, caracterização das raças bovinas e para projetos de conservação numa escala internacional, o que possibilita uma comparação objetiva devido à uniformização dos marcadores utilizados. No ano de 2004 a lista foi ampliada com a inclusão de novos marcadores.

Algumas raças crioulas vêm sendo caracterizadas geneticamente com microssatélites visando contribuir para a sua conservação, como nos mostram Egito et al (2004) com raças nativas brasileiras, incluindo a Pé-duro. A raça foi estudada citogeneticamente por Britto (1998) e através de RAPD por Serrano et al (2004); também foi incluída em estudos de filogeografia através do DNA mitocondrial (Miretti et al, 2004).

Na literatura mundial, selecionamos alguns estudos feitos em diferentes localidades, todos eles dando ênfase a raças bovinas nativas, os quais passamos a resumir.

Na América do Sul, a caracterização genética através de microssatélites de raças nativas foi realizada por Armstrong et al (2006) com o gado crioulo do Uruguai, 
por Sastre (2003) e Barrera et al (2006) com o gado crioulo colombiano. Na Europa onde foram feitos a maioria dos estudos - salientamos Maudet et al (2002) com as raças nativas Abondance e Tarentaise da França, Casellas et al (2004) com a raça nativa Alberes da Catalunha, Chikhi et al (2004) com a raça nativa Insular Jersey do Reino Unido, e Mateus et al (2004) com raças nativas de Portugal. Raças nativas do nordeste da Ásia foram estudadas por Kim et al (2002) na China, Coréia e Japão; ainda na Ásia, Mukesh et al (2004) estudaram na Índia as raças Hariana e Deoni e a raça nativa Sahiwal do Paquistão. Na África merece destaque o trabalho de Ibeagha-Awemu e Erhardt (2005) com as raças Namchi, Muturu e N’Dama, todas Bos taurus. 
II. OBJETIVOS 
De acordo com o que foi exposto, é notável a importância social, econômica e biológica dos bovinos, justificando estudos que auxiliem no conhecimento da composição genética e estrutura populacional da espécie. No nosso caso, utilizamos um rebanho da raça Pé-duro, visando:

$\checkmark$ Caracterizar geneticamente uma amostra populacional através de locos de marcadores moleculares microssatélites (STRs).

$\checkmark$ Estimar a variabilidade genética através das freqüências gênicas, heterozigose e conteúdo de informação do polimorfismo (Pic).

$\checkmark$ Verificar se a população está em Equilíbrio de Hardy-Weinberg.

$\checkmark$ Comparar os dados obtidos com dados da literatura de outras raças nativas.

$\checkmark$ A partir dos dados obtidos colaborar com o Núcleo de Conservação in situ em São João do Piauí para uma efetiva conservação da raça Pé-duro. 


\section{MATERIAL E MÉTODOS}




\subsection{Amostra estudada}

O DNA genômico foi obtido a partir de sangue coletado em uma amostra (n=126) de um rebanho da raça Pé-duro do estado do Piauí, mantido na Fazenda Experimental Octavio Domingues, da Embrapa Meio-Norte, no município de São João do Piauí. As amostras foram coletadas por Marcos Miretti em julho de 2003 e o DNA foi extraído segundo a metodologia de Higuchi (1989). Desde então estas amostras estão estocadas e conservadas no Laboratório de Genética Bioquímica da FMRP.

\subsection{Marcadores microssatélites investigados}

Dez marcadores microssatélites foram analisados, conforme consta da Tabela 1. Sete das seqüências - SPS115, BM1824, BM2113, TGLA122, ETH225, ETH10 e INRA23 - fazem parte das 30 recomendadas pela FAO e pela ISAG para estudo de diversidade genética de bovinos. As seqüências BMS4049 e UWCA46 (Tabela 1) foram estudadas porque são marcadores associados a características quantitativas de interesse econômico (QTL - quantitative trait loci) (Malau-Aduli et al, 2007). O marcador BMS348 foi estudado por estar localizado no cromossomo 14 (Kappes et al, 1997), próximo ao loco codificador da anidrase carbônica, considerado muito informativo nos estudos de caracterização de raças bovinas (Lara et al, 2005). 
Tabela 1 - Marcadores microssatélites, localização cromossômica (Cr.), seqüência do iniciador e tamanho dos fragmentos descritos (pb) para os dez locos analisados.

\begin{tabular}{|c|c|c|c|c|}
\hline $\begin{array}{l}\text { Marcadores } \\
\text { Microssatélites }\end{array}$ & Cr. & $\begin{array}{c}\text { Seqüência do iniciador } \\
\text { (5' -> 3') Forward } \\
\text { Reverse }\end{array}$ & $\begin{array}{l}\text { Tamanho } \\
\text { (bp) }\end{array}$ & Referência \\
\hline SPS115 & 15 & $\begin{array}{l}\text { AAAGTGACACAACAGCTTCTCCAG } \\
\text { AACGAGTGTCCTAGTTTGGCTGTG }\end{array}$ & $234-258$ & Peelman et al (1998) \\
\hline BM1824 & 1 & $\begin{array}{l}\text { GAGCAAGGTGTTTTTCCAATC } \\
\text { CATTCTCCAACTGCTTCCTTG }\end{array}$ & $176-197$ & Bishop et al (1994) \\
\hline BM2113 & 2 & $\begin{array}{l}\text { GCTGCCTTCTACCAAATACCC } \\
\text { CTTCCTGAGAGAAGCAACACC }\end{array}$ & $122-156$ & $\begin{array}{l}\text { Maudet et al (2002) } \\
\text { Peelman et al (1998) }\end{array}$ \\
\hline BMS4049 & 1 & $\begin{array}{l}\text { GATCAAGTTGTCAACACACACAC } \\
\text { TCTCATTTCTCTCCCTGTGC }\end{array}$ & $91-111$ & Stone et al (1996) \\
\hline TGLA122 & 21 & $\begin{array}{l}\text { CCCTCCTCCAGGTAAATCAGC } \\
\text { AATCACATGGCAAATAAGTACATAC }\end{array}$ & $136-184$ & $\begin{array}{l}\text { Maudet et al (2002) } \\
\text { Peelman et al (1998) }\end{array}$ \\
\hline ETH225 & 9 & $\begin{array}{l}\text { GATCACCTTGCCACTATTTCCT } \\
\text { ACATGACAGCCAGCTGCTACT }\end{array}$ & 131-159 & Fries et al (1993) \\
\hline ETH10 & 5 & $\begin{array}{l}\text { GTTCAGGACTGGCCCTGCTAACA } \\
\text { CCTCCAGCCCACTTTCTCTTCTC }\end{array}$ & $207-231$ & $\begin{array}{l}\text { Steffen et al (1993) } \\
\text { Vaiman et al (1994) }\end{array}$ \\
\hline INRA23 & 3 & $\begin{array}{l}\text { GAGTAGAGCTACAAGATAAACTTC } \\
\text { TAACTACAGGGTGTTAGATGAACTC }\end{array}$ & $195-222$ & Vaiman et al (1994) \\
\hline UWCA46 & 1 & $\begin{array}{l}\text { CCATTTCTCTGTTGGTAACTGC } \\
\text { CTCTCACAGGTGGGGTC }\end{array}$ & $120-147$ & Sun et al (1995) \\
\hline BMS348 & 14 & $\begin{array}{l}\text { TTTTATGTGCACCACCCG } \\
\text { ACTCACTGGCTCTCAATGACTC }\end{array}$ & $158-182$ & Stone et al (1995) \\
\hline
\end{tabular}

\subsection{Amplificações por PCR}

As amplificações por PCR foram realizadas com 200 ng de DNA genômico, 1,5 $\mathrm{mM}$ a 4,0 mM de $\mathrm{MgCl}_{2}, 200 \mu \mathrm{M}$ de cada dNTP, $0,150 \mu \mathrm{M}$ a 0,200 $\mu \mathrm{M}$ para os iniciadores microssatélites, $2,5 \mu$ l de tampão de reação fornecido com a enzima para a concentração de 10X, 1U/ $\mu$ l de Taq DNA polimerase (Biotools) e água desionizada 
para completar o volume final até $25 \mu$ l (Tabela 2). A mistura total da PCR foi submetida ao termociclador modelo Robocycler 40 marca Stratagene, utilizando diferentes programas para cada loco (Tabela 3).

Tabela 2. Condições de amplificação dos locos microssatélites utilizando a técnica de PCR.

\begin{tabular}{l|lllll}
\hline Microssatélites & $\begin{array}{l}\mathbf{T m}^{\mathbf{0}} \\
\left.{ }^{\circ} \mathrm{C}\right)\end{array}$ & $\begin{array}{l}\left.\text { [MgCl }_{2}\right] \\
(\mathrm{mM})\end{array}$ & $\begin{array}{l}\text { [STRs] } \\
(\mu M)\end{array}$ & $\begin{array}{l}\text { dNTP } \\
(\mu M)\end{array}$ & $\begin{array}{l}\text { Taq DNA } \\
(U / \mu l)\end{array}$ \\
\hline SPS115 & $58-63^{\circ}$ & 1,5 & 0,175 & 200 & 0,5 \\
BM1824 & $58-63^{\circ}$ & 1,5 & 0,150 & 200 & 0,5 \\
BM2113 & $58-63^{\circ}$ & 1,5 & 0,175 & 200 & 0,5 \\
BMS4049 & $55^{\circ}$ & 3,0 & 0,150 & 200 & 0,5 \\
TGLA122 & $45^{\circ}$ & 3,0 & 0,180 & 200 & 0,5 \\
ETH225 & $57^{\circ}$ & 3,0 & 0,150 & 200 & 0,5 \\
ETH10 & $55^{\circ}$ & 3,0 & 0,100 & 200 & 0,5 \\
INRA23 & $50^{\circ}$ & 4,0 & 0,200 & 200 & 0,5 \\
UWCA46 & $57^{\circ}$ & 4,0 & 0,150 & 200 & 0,3 \\
BMS348 & $58^{\circ}$ & 4,0 & 0,150 & 200 & 0,3 \\
\hline
\end{tabular}

\subsection{Determinação fenotípica}

Os produtos amplificados foram analisados por eletroforese em gel de poliacrilamida 12\% desnaturante (uréia) e 10\% não desnaturante (glicerol), seguida de coloração com nitrato de prata de acordo com o protocolo de Sanguinetti et al (1994). Os alelos foram identificados por ordem crescente de tamanho; foi utilizada uma fonte Amersham Pharmacia Biotech (EPS 1001) ajustada à voltagem ou corrente constante necessária para uma boa separação dos fragmentos amplificados. A estimativa do tamanho em pares de base (pb) no gel não desnaturante foi verificada utilizando-se o 
Tabela 3. Programas utilizados para amplificação dos locos microssatélites.

\begin{tabular}{|c|c|c|c|c|c|c|c|}
\hline \multicolumn{8}{|c|}{ Locos } \\
\hline $\begin{array}{l}B M 1824 \\
B M 2113 \\
\end{array}$ & BMS4049 & TGLA122 & ETH225 & ЕTH10 & INRA23 & UWCA46 & BMS348 \\
\hline $\begin{array}{l}1 \text { ciclo: } \\
94^{\circ} \mathrm{C}-5\end{array}$ & $\begin{array}{l}1 \text { ciclo: } \\
94^{\circ} \mathrm{C}-1\end{array}$ & $\begin{array}{c}1 \text { ciclo: } \\
95^{\circ} \mathrm{C}-10\end{array}$ & $\begin{array}{l}1 \text { ciclo: } \\
94^{\circ} \mathrm{C}-1\end{array}$ & $\begin{array}{l}1 \text { ciclo: } \\
94^{\circ} \mathrm{C}-1\end{array}$ & $\begin{array}{l}1 \text { ciclo: } \\
94^{\circ} \mathrm{C}-5\end{array}$ & $\begin{array}{l}1 \text { ciclo: } \\
94^{\circ} \mathrm{C}-5\end{array}$ & $\begin{array}{l}1 \text { ciclo: } \\
94^{\circ} \mathrm{C}-5\end{array}$ \\
\hline $\begin{array}{l}5 \text { ciclos: } \\
94^{\circ} \mathrm{C}-1 \\
63^{\circ} \mathrm{C}-1 \\
72^{\circ} \mathrm{C}-1\end{array}$ & - & - & - & - & - & - & - \\
\hline $\begin{array}{l}30 \text { ciclos: } \\
94^{\circ} \mathrm{C}-1 \\
58^{\circ} \mathrm{C}-1 \\
72^{\circ} \mathrm{C}-1\end{array}$ & $\begin{array}{l}35 \text { ciclos: } \\
94^{\circ} \mathrm{C}-1 \\
55^{\circ} \mathrm{C}-1 \\
72^{\circ} \mathrm{C}-1\end{array}$ & $\begin{array}{c}35 \text { ciclos: } \\
95^{\circ} \mathrm{C}-30^{\circ} \\
45^{\circ} \mathrm{C}-1 \\
72^{\circ} \mathrm{C}-1\end{array}$ & $\begin{array}{l}35 \text { ciclos: } \\
94^{\circ} \mathrm{C}-1 \\
57^{\circ} \mathrm{C}-1 \\
72^{\circ} \mathrm{C}-1\end{array}$ & $\begin{array}{l}38 \text { ciclos: } \\
94^{\circ} \mathrm{C}-1 \\
55^{\circ} \mathrm{C}-1 \\
72^{\circ} \mathrm{C}-1\end{array}$ & $\begin{array}{c}32 \text { ciclos: } \\
94^{\circ} \mathrm{C}-40^{\prime} \\
50^{\circ} \mathrm{C}-1 \\
72^{\circ} \mathrm{C}-1\end{array}$ & $\begin{array}{c}32 \text { ciclos: } \\
94^{\circ} \mathrm{C}-40^{\prime} \\
57^{\circ} \mathrm{C}-1 \\
72^{\circ} \mathrm{C}-1\end{array}$ & $\begin{array}{c}32 \text { ciclos: } \\
94^{\circ} \mathrm{C}-40^{\prime} \\
58^{\circ} \mathrm{C}-1 \\
72^{\circ} \mathrm{C}-1\end{array}$ \\
\hline $\begin{array}{c}1 \text { ciclo: } \\
72^{\circ} \mathrm{C}-10\end{array}$ & $\begin{array}{c}1 \text { ciclo: } \\
72^{\circ} \mathrm{C}-10\end{array}$ & $\begin{array}{c}1 \text { ciclo: } \\
72^{\circ} \mathrm{C}-20^{\prime}\end{array}$ & $\begin{array}{c}1 \text { ciclo: } \\
72^{\circ} \mathrm{C}-20^{\prime}\end{array}$ & $\begin{array}{l}1 \text { ciclo: } \\
72^{\circ} \mathrm{C}-20^{\prime}\end{array}$ & $\begin{array}{c}1 \text { ciclo: } \\
72^{\circ} \mathrm{C}-10\end{array}$ & $\begin{array}{c}1 \text { ciclo: } \\
72^{\circ} \mathrm{C}-10\end{array}$ & $\begin{array}{c}1 \text { ciclo: } \\
72^{\circ} \mathrm{C}-10\end{array}$ \\
\hline
\end{tabular}


marcador molecular DNA Ladder Invitrogen de peso molecular de 25pb e 50pb. No gel desnaturante, o tamanho em pares de base (pb) foi verificado colocando-se em ordem ascendente todos os alelos de cada loco, obtidos na amplificação das amostras, intercalando-se padrões seqüenciados que amplificavam na mesma região que os alelos observados nos locos em Pé-duro. Os padrões seqüenciados foram gentilmente cedidos pela bióloga Maria do Carmo Tomitão Canas, do Laboratório de Genética de Populações-Investigação de Paternidade, FMRP-USP. Todos os alelos encontrados foram comparados entre si e, após uma leitura prévia, aquelas amostras que a princípio pareciam conter o mesmo alelo foram comparadas lado a lado em outro gel, para confirmação de suas leituras. Após a corroboração foram escolhidos padrões precisos de leitura para tipagem das demais amostras.

\subsection{Análises estatísticas}

As freqüências alélicas em cada loco foram estimadas por contagem direta na população Pé-duro pelo programa GENEPOP, versão 3.0 (Raymond e Rousset, 1995) e utilizadas para calcular a aderência ao equilíbrio de Hardy-Weinberg. O programa GDA versão 1.0 (Lewis e Zaykin, 1997) foi empregado para estimar as heterozigoses esperada, observada e média, e a estatística F pela análise do Fis (coeficiente de endogamia), de acordo com a fórmula desenvolvida por Nei (1987); os valores de diversidade gênica e riqueza alélica foram calculados pelo programa FSTAT, versão 2.9.3 (Goudet, 2001), e os valores de Pic (conteúdo de informação de polimorfismo) para cada marcador microssatélite foram calculados pelo programa Cervus, versão 3.0.3 (Marshall et al, 1998). 


\subsubsection{Estimativas das freqüências alélicas e genotípicas}

Os locos STRs apresentam alelos codominantes o que permite inferir os genótipos a partir dos respectivos fenótipos. As freqüências alélicas $\left(x_{i}\right)$ e genotípicas $\left(X_{i i}\right)$ de cada loco em Pé-duro foram estimadas por contagem direta, utilizando-se o programa GENEPOP, versão 3.0 (Raymond e Rousset, 1995) segundo as equações:

$$
x_{i}=\frac{2 n_{i i}+\sum n_{i j}}{2 n} \quad \text { e } \quad X_{i i}=\frac{n_{i i}}{n}
$$

Em que:

$x_{i}$ é a freqüência do alelo “i”;

$X_{i i}$ é a freqüência do genótipo “ii”;

$n_{i i}$ e $n_{i j}$ correspondem ao número de homozigotos e heterozigotos observados para o alelo i, respectivamente;

$n$ corresponde ao número de indivíduos analisados.

3.5.2 Heterozigose intraloco observada, esperada e conteúdo de informação de polimorfismo

A comparação das distribuições das freqüências alélicas foi realizada pelo teste exato de Fisher. Com esta mesma ferramenta foi estimada, para cada loco, a heterozigose intraloco observada $\left(\mathrm{H}_{\mathrm{o}}\right)$ e esperada $\left(\mathrm{H}_{\mathrm{e}}\right)$ usando o Genetic Data Analysis Package GDA (Lewis e Zaykin, 1997); o conteúdo de informação de polimorfismo foi calculado usando o programa Cervus, versão 3.0.3 (Marshall et al, 1998).

\section{Heterozigose intraloco observada $\left(\mathrm{H}_{0}\right)$}

$$
H_{o}=\underline{\text { número de heterozigotos observados no loco } i}
$$

número total de indivíduos 
Heterozigose intraloco esperada $\left(\mathrm{H}_{\mathrm{e}}\right)$

$$
H_{e}=\frac{\text { número de heterozigotos esperados no loco } i}{\text { número total de indivíduos }}
$$

\section{Conteúdo de informação de polimorfismo}

$$
\text { Pic }=1-\left(\sum p_{i}^{2}\right)_{i=1}^{n}-\sum \sum_{i=1}^{n-1} 2 p_{i}^{2^{n}} p_{j=i+1}^{2}
$$

Onde: $p_{i}$ e $p_{j}$ são as freqüências alélicas

\subsubsection{Aderência ao equilíbrio de Hardy-Weinberg}

Segundo o teorema de Hardy-Weinberg, as freqüências genotípicas esperadas no equilíbrio podem ser estimadas a partir da expansão do seguinte binômio:

$$
\left(x_{i}+x_{j}\right)^{2}=x_{i}^{2}+2 x_{i} x_{j}+x_{j}^{2}
$$

Em que:

$x_{i}^{2}$ é a freqüência esperada dos homozigotos para o alelo i;

$2 x_{i} x_{j}$ é a freqüência esperada dos heterozigotos ij;

$x_{j}^{2}$ é a freqüência esperada dos homozigotos para o alelo j.

A aderência das freqüências genotípicas observadas às proporções teóricas de Hardy-Weinberg foi verificada com o emprego do programa GENEPOP, versão 3.0 (Raymond e Rousset, 1995) para Windows ${ }^{\circledR}$. Foram realizados três testes baseados na hipótese nula de união aleatória dos gametas: teste exato de probabilidade global, teste para detecção da deficiência e teste para detecção do excesso de heterozigotos. Em todos os testes, o valor de $\mathrm{P}$ foi efetuado utilizando-se o procedimento da cadeia de Markov (1000 “dememorization”, 100 “batches”, 1000 “iterations”). 


\subsubsection{Diversidade gênica}

A estimativa da diversidade gênica $\left(\mathrm{H}_{\mathrm{S}}\right)$ por loco e por amostra, foi obtida de acordo com a equação proposta por Nei (1987), utilizando-se o programa FSTAT 2.9.3 (Goudet, 2001).

$$
H_{s k}=\frac{n_{k}}{n_{k}-1}\left(1-\sum p_{i k}^{2}-H_{o k} / 2 n_{k}\right)
$$

Em que:

$H_{s k}$ é a heterozigose média dentro da população k, ou diversidade gênica;

$n_{k}$ é o tamanho da k-ésima amostra,

$P_{i k}$ é a freqüência do alelo i na amostra k, e

$H_{o k}$ é a proporção de heterozigotos observada na amostra da população k.

A estatística F, análise do Fis, foi obtida como descrito por Nei (1987), usando o Genetic Data Analysis Package GDA (Lewis e Zaykin, 1997). O valor de Fis foi estimado para cada loco e amostra.

$$
F_{i s}^{k}=1-\frac{H_{o}^{k}}{H_{s}^{k}}
$$

Em que:

$F_{i s}{ }^{k}$ é o coeficiente de endogamia dentro de uma população k (déficit de heterozigotos dentro de uma população);

$H_{o}{ }^{k}$ é a proporção observada de heterozigotos na amostra da população k; $H_{s}^{k}$ é a heterozigose média dentro da população k, ou diversidade gênica. 


\subsubsection{Riqueza alélica}

Riqueza alélica é uma medida de variação genética do número médio de alelos por loco ou de diversidade alélica. O número observado de alelos em uma amostra é altamente dependente do tamanho da amostra. Para evitar este problema, El Mousadik e Petit (1996) sugeriram adaptar o índice de rarefação de Hurlbert (1971) para genética de populações (Petit et al, 1998). A riqueza alélica foi calculada pelo programa FSTAT versão 2.9.3 (Goudet, 2001), onde $R$ é a estimativa de riqueza alélica por loco e por amostra. O princípio é calcular o número esperado de alelos em uma amostra substituta de $2 n$ genes, dado que $2 N$ genes foram amostrados $(N \geq n)$. Ni é o número de alelos do tipo $i$ entre os $2 N$ genes, e o $n$ é fixo como o menor número de indivíduos tipados para um loco em uma amostra. De acordo com Leberg (2002) é necessário padronizar e corrigir o valor de $n$, pois a comparação entre vários tamanhos de amostra de vários trabalhos diferentes se tornaria complicada. No presente trabalho o valor fixo de $n$ foi considerado e ajustado ao valor de um indivíduo diplóide ( $n=1)$, ou seja, a probabilidade de um alelo ser representado pelo menos uma vez em uma amostra de um indivíduo 2n, permitindo assim uma real comparação com o trabalho de Sastre (2003).

A riqueza alélica é então calculada como:

$$
R_{s}=\sum_{i=1}^{n_{i}}\left[1-\frac{\left(\frac{2 N-N_{i}}{2 n}\right)}{\left(\frac{2 N}{2 n}\right)}\right]
$$


IV. RESULTADOS 


\subsection{Diversidade genética dentro da população Pé-duro}

Foram identificados 101 alelos nos dez locos analisados, com um número médio de 10,1 alelos por loco. Esse número variou de três alelos em BMS348 a 20 alelos em TGLA122 (Tabela 4). O número de alelos por loco, com exceção de BMS348, está de acordo com os parâmetros de diversidade recomendados pela FAO, a qual sugere pelo menos cinco alelos por loco para ser considerado um bom indicador de variabilidade genética (Tabela 4).

Os valores de riqueza alélica foram calculados para cada loco e variaram de 1,455 em BMS4049 e 1,51 em BMS348 a 1,912 em TGLA122 e UWCA46 (Tabela 4 e Gráfico 1). Em um total de 101 alelos encontrados em Pé-duro foi verificado o valor médio de riqueza alélica de 1,748, com base em uma amostra mínima de um indivíduo diplóide (2n), ou seja, a probabilidade de um alelo ser representado pelo menos uma vez em uma amostra de um indivíduo 2n (Tabela 4 e Gráfico 1).

As freqüências alélicas calculadas para cada loco mostraram que todos eles apresentaram alelos com freqüência muito baixa $(<0,100)$ com apenas um ou dois com freqüência alta; isso pode ser exemplificado pelo loco BMS4049 com o alelo 3 mais freqüente (71,8\%), e pelo loco BMS348 com o alelo 2 mais freqüente (59,6\%), mas a situação também pôde ser verificada em outros locos. Os locos que apresentaram uma distribuição alélica mais uniforme foram TGLA122, ETH10, INRA23 e UWCA46 (Tabela 5).

A população Pé-duro apresentou valores significativos de diversidade gênica com o valor médio de 75,6\%; o maior valor encontrado foi 91,3\%, nos locos TGLA122 e UWCA46. As exceções ocorreram nos locos BMS4049 - 45,5\% - e BMS348 - 50,2\% (Tabela 6 e Gráfico 2). O valor médio da heterozigose esperada foi de 75,5\%, da observada foi de $60 \%$ e, de uma maneira geral, todos os locos apresentaram valores 
maiores de heterozigose esperada em relação à observada. O loco BM1824 foi o único que apresentou valores iguais de diversidade gênica (76,4\%), de heterozigose esperada (76,4\%) e observada (76,2\%) (Tabela 6 e Gráfico 2).

Foram observados valores significativos de Pic na maioria dos locos analisados no presente trabalho, os maiores em TGLA122 - 90,2\% - e UWCA46 90,1\% - indicando assim alta diversidade e polimorfismo, uma vez que valores de Pic maiores que 0,50 são considerados mais informativos; exceções foram observadas nos locos BMS4049, com 42,0\%, e BMS348, com 39,7\% (Tabela 6 e Gráfico 2).

O valor do coeficiente de endogamia Fis observado na população Pé-duro, considerando todos os locos, foi estatisticamente significativo (Fis=0,206; $\mathrm{P}<0,01$ ), com o menor valor observado no loco BM1824 $(0,002)$ e o maior valor em ETH225 (0,390) (Tabelas 6 e 7 e Gráfico 3).

As análises realizadas com os marcadores microssatélites revelaram desvios significativos do equilíbrio de Hardy-Weinberg $(\mathrm{p}<0,05)$ em todos os locos analisados no teste exato, com exceção do loco BMS348 (Tabela 8). Foram aplicados dois testes mais sensíveis do que o teste exato, para averiguar se o desvio era causado por déficit ou excesso de heterozigotos. Estes testes indicaram desvios significativos do equilíbrio de HardyWeinberg $(\mathrm{p}<0,05)$ devido à falta de heterozigotos em sete dos dez locos analisados, SPS115, BM2113, TGLA122, ETH225, ETH10, INRA23 e UWCA46 (Tabela 8).

\subsection{Diversidade genética comparativa entre a população Pé-duro e populações nativas de Bos taurus.}

\subsubsection{Diversidade gênica}

Conforme salientado na Introdução e nos Objetivos procuramos fazer uma análise comparativa entre os dados obtidos com a raça Pé-duro e os obtidos com outras 
raças nativas, de várias localidades. Para tanto utilizamos dados publicados sobre a raça crioula colombiana Casanare (Sastre, 2003), uma raça crioula do Uruguai (Armstrong et al, 2006) a raça nativa Jersey, da Ilha de Jersey (Chikhi et al, 2004), assim como dois trabalhos desenvolvidos com algumas raças nativas asiáticas (Kim et al, 2002) e com raças nativas da Europa (Cañón et al, 2001).

As raças nativas asiáticas estudadas por Kim et al (2002) se constituíram de quatro da Coréia (Gohung, Paju, Haman e Sanji; n=105) uma da China (Gado Chinês; n=41) e uma do Japão (Gado Negro Japonês; n=36). As européias englobaram nativas da Espanha (Alistana, Asturiana, Montana, Asturiana Valles, Sayaguesa, Tudanca Arileña, Bruna del Pirineus, Morucha, Pirenoica e Retinta), de Portugal (Alentejana, Barrosa, Maronesa, Mertolenga e Mirandesa) e da França (Aubrac, Gascone e Salers). De cada uma dessas últimas foram analisados 50 indivíduos, num total amostral de 899. Também utilizamos em uma das comparações (Tabela 10 e Gráficos 10 e 12) um trabalho desenvolvido por Mateus et al (2004) apenas com raças nativas portuguesas englobando a Alentejana, Arouquesa, Barrosa, Brava de Lide, Garvonesa, Minhota, Mertolenga, Maronesa e Mirandesa ( $\mathrm{n}=470)$.

Foi possível também fazer comparações com uma raça da Catalunha, a Alberes ( $\mathrm{n}=82)$ e com três raças africanas de Bos taurus, a Namchi $(\mathrm{n}=30)$, a Muturu $(\mathrm{n}=20)$ e a N’Dama (n=26). O trabalho com o gado catalão foi desenvolvido por Casellas et al (2004) e o trabalho com o gado africano por Ibeagha-Awemu e Erhardt (2005).

Os dados relativos à diversidade gênica estão mostrados na Tabela 9, onde podemos observar uma diversidade gênica bem acentuada em todas essas populações de Bos taurus. Os maiores valores em todos os locos foram observados em Pé-duro seguindo-se a raça Casanare da Colômbia e populações de raças nativas da Europa com valores médios de $81,3 \%$, 76,0\% e 74,7\%, respectivamente. Considerando-se cada loco 
separadamente, a variação entre essas três populações é pequena (Tabela 9 e Gráficos 4, 5 e 9). As populações das raças crioula do Uruguai, asiáticas e Jersey apresentaram valores médios de diversidade gênica semelhantes entre si, 66,7\%, 66,0\% e 63,3\%, respectivamente, e menores que os observados na Pé-duro (81,3\%) (Tabela 9 e Gráficos 6, 7 e 8). O loco ETH10 foi o que mostrou maior discrepância entre o valor obtido para a Pé-duro (88\%) e os valores obtidos para as raças asiáticas $(58,4 \%)$, crioula do Uruguai (58\%) e a Jersey (62,4\%). Em relação ao loco TGLA122, o valor obtido para a Pé-duro (91,3\%) foi muito maior do que o descrito para a Jersey $(65,7 \%)$.

\subsubsection{Número de alelos amostrados}

Foi possível fazer uma análise comparativa do número de alelos amostrados por loco e o número médio entre a nossa população Pé-duro, a crioula Casanare da Colômbia, (Sastre, 2003), outro estudo com raças nativas de Portugal (Mateus et al, 2004), a crioula do Uruguai (Armstrong et al, 2006), e a raça nativa Jersey do Reino Unido (Chikhi et al, 2004) (Tabela 10 e Gráfico 10). As análises comparativas da população Pé-duro com cada uma das outras utilizadas (Gráficos 11 a 14) foram mais informativas em relação à Casanare e as portuguesas, pela coincidência dos locos escolhidos. O número médio de alelos não foi diferente entre a Pé-duro e essas raças nativas portuguesas (11,3 e 11,0, respectivamente) e, com exceção do loco TGLA122, também não foi muito diferente entre a Pé-duro e a Casanare da Colômbia.

\subsubsection{Heterozigose observada}

Os valores comparativos de heterozigose observada por loco e o valor médio para cada população foi verificado entre a Pé-duro e a Casanare (Sastre, 2003), a crioula do Uruguai (Armstrong et al, 2006) e a raça nativa Jersey do Reino Unido (Chikhi et al, 2004). Os valores de heterozigose média observados foram 62,3\% em Pé-duro, 75,3\% 
em Casanare, (o maior valor observado), 67,5\% na crioula do Uruguai e 66,6\% em Jersey (Tabela 11 e Gráfico 15). De uma maneira geral foram verificados valores menores de heterozigose observada em Pé-duro na maioria dos locos; isso pode ser observado no loco SPS115 com 57,6\%, enquanto que em Casanare foi de 73,8\% (Tabela 11 e Gráfico 16), e também no loco BM2113, com 62,1\%, enquanto que na raça crioula do Uruguai foi de 78,8\% (Tabela 11 e Gráfico 17). O menor valor observado em Pé-duro foi no loco ETH225 (47,6\%) enquanto que a população Jersey apresentou valor igual a 60,9\% no mesmo loco (Tabela 11 e Gráfico 18). Entretanto, no loco BM1824, Pé-duro apresentou um valor maior de heterozigose observada $(76,2 \%)$ em relação à raça Casanare (69,5\%) (Tabela 11 e Gráfico 16).

\subsubsection{Coeficiente de endogamia (Fis)}

Foi possível comparar os valores obtidos do coeficiente de endogamia por loco com a raça crioula da Colômbia (Sastre, 2003), com raças nativas da Espanha, Portugal e França (Cañón et al, 2001), com a raça nativa Alberes da Catalunha (Casellas et al, 2004) e com três raças nativas da África, a Namchi, a Muturu e a N’Dama (Ibeagha-Awemu e Erhardt, 2005). Como pode ser verificado na Tabela 12 e nos gráficos 19 a 22, os dados são muito discrepantes, com exceção do loco INRA23, onde os valores observados do coeficiente de endogamia em Pé-duro e em uma das populações africanas - N’Dama - foram muito semelhantes, 0,334 e 0,351, respectivamente. Em relação ao loco SPS115 o coeficiente de endogamia não diferiu muito entre Pé-duro $(0,162)$, Casanare da Colômbia $(0,100)$ e raças nativas da Espanha, Portugal e França $(0,118)$.

\subsubsection{Riqueza alélica}

Os valores comparativos de riqueza alélica por loco e o valor médio foi verificado em Pé-duro e na Casanare da Colômbia, Sastre (2003). Como pode ser visto 
na Tabela 13 e no Gráfico 23, os valores observados tanto para a riqueza alélica média como para cada um dos cinco locos comparados, foram muito próximos.

\subsection{Diversidade genética comparativa entre a população Pé-duro e populações} nativas da Índia Bos indicus.

Para essa análise comparativa utilizamos dados de raças nativas indianas, a Sahiwal (n=48) do Paquistão e norte da Índia, a Hariana $(\mathrm{n}=40)$ do norte da Índia e a Deoni (n=48) da região oeste da Índia (Radko et al, 2005).

Os valores do número de alelos por loco estão mostrados na Tabela 15 e Gráfico 24. Como pode ser observado, houve coincidência de apenas dois locos nas populações nativas da Índia, com os demais analisados em Pé-duro. As três populações indianas apresentaram menor número de alelos nos dois locos e menor média do número de alelos em relação a Pé-duro. Quando analisamos o conteúdo de informação de polimorfismo (Tabela 16 e Gráfico 25) também podemos verificar maiores valores da média dos dois locos analisados em Pé-duro em relação às raças indianas. Quando a análise é feita separadamente por loco, observamos no loco ETH225 valores próximos entre Pé-duro e a população Deoni (0,745 e 0,690 respectivamente) e também no loco ETH10 entre Pé-duro e a população Hariana (0,864 e 0,750 respectivamente).

4.4 Diversidade genética comparativa entre Pé-duro e raças comerciais de Bos taurus e Bos indicus.

As raças comerciais de Bos indicus (Gir e duas populações de Nelore) haviam sido estudadas em rebanhos brasileiros por Curi e Lopes (2002), Cervini et al (2006) e Lara et al (2005); as de Bos taurus (Polish Red, Hereford e Holstein-Friesian), por Mukesh et al (2004). 


\subsubsection{Número de alelos amostrados}

O número de alelos por loco assim como o valor médio de alelos por loco nas sete populações estão mostrados na Tabela 17 e Gráficos 26 e 27. Em uma das populações da raça Nelore e na população da raça Gir houve coincidência de quatro locos, entre os nove analisados em Pé-duro. Houve mais coincidência com os analisados nas três raças comerciais de Bos taurus, isto é, Polish Red, Hereford e Holstein-Friesian. A média do número de alelos no total de locos analisados foi muito próxima entre Péduro $(11,3)$ e Polish Red $(9,0)$, mas diferiu entre a nossa amostra e as outras duas de Bos taurus: Hereford $(5,0)$ e Holstein-Friesian $(6,0)$.

Em relação a Bos indicus, em uma população de gado Nelore, com 200 indivíduos analisados, a média do número de alelos em seis dos nove locos analisados em Pé-duro, não foi muito diferente (9,8 e 11,3, respectivamente). O loco SPS115 foi o que apresentou uma distribuição mais uniforme, em cinco populações.

\subsubsection{Conteúdo de informação de polimorfismo.}

A análise comparativa do conteúdo de informação de polimorfismo por loco e a média para cada população estão ilustradas na Tabela 18 e Gráficos 28 e 29. Na tabela 18 podemos verificar que sete dos nove locos analisados em Pé-duro também foram estudados nas raças Bos taurus Polish Red, Hereford e Holstein-Friesian. Os valores obtidos considerando-se as quatro amostras não foram muito discrepantes, com exceção dos locos TGLA122, ETH10 e INRA23; nesse último, entretanto, os valores observados em Pé-duro e Polish Red são próximos.

Quando comparamos Pé-duro com a amostra de Nelore (Bos indicus) com 200 indivíduos também podemos estabelecer uma correspondência do conteúdo de informação de polimorfismo em todos os locos analisados nas duas investigações, com exceção do loco ETH10. 
4.5 Tabelas e Gráficos

Tabela 4. Número de alelos, Riqueza Alélica por loco baseada numa amostra mínima de um indivíduo diplóide (2n).

\begin{tabular}{l|lc}
\hline Locos & $\mathbf{N}^{\mathbf{0}}$ Alelos & Riqueza Alélica \\
\hline SPS115 & 6 & 1,688 \\
BM1824 & 6 & 1,764 \\
BM2113 & 5 & 1,772 \\
BMS4049 & 20 & 1,455 \\
ETHA122 & 11 & 1,912 \\
ETH10 & 12 & 1,780 \\
INRA23 & 15 & 1,789 \\
UWCA46 & 14 & 1,897 \\
BMS348 & 3 & 1,912 \\
\hline Valor médio & $\mathbf{1 0 , 1}$ & $\mathbf{1 , 7 4 8}$ \\
\hline
\end{tabular}




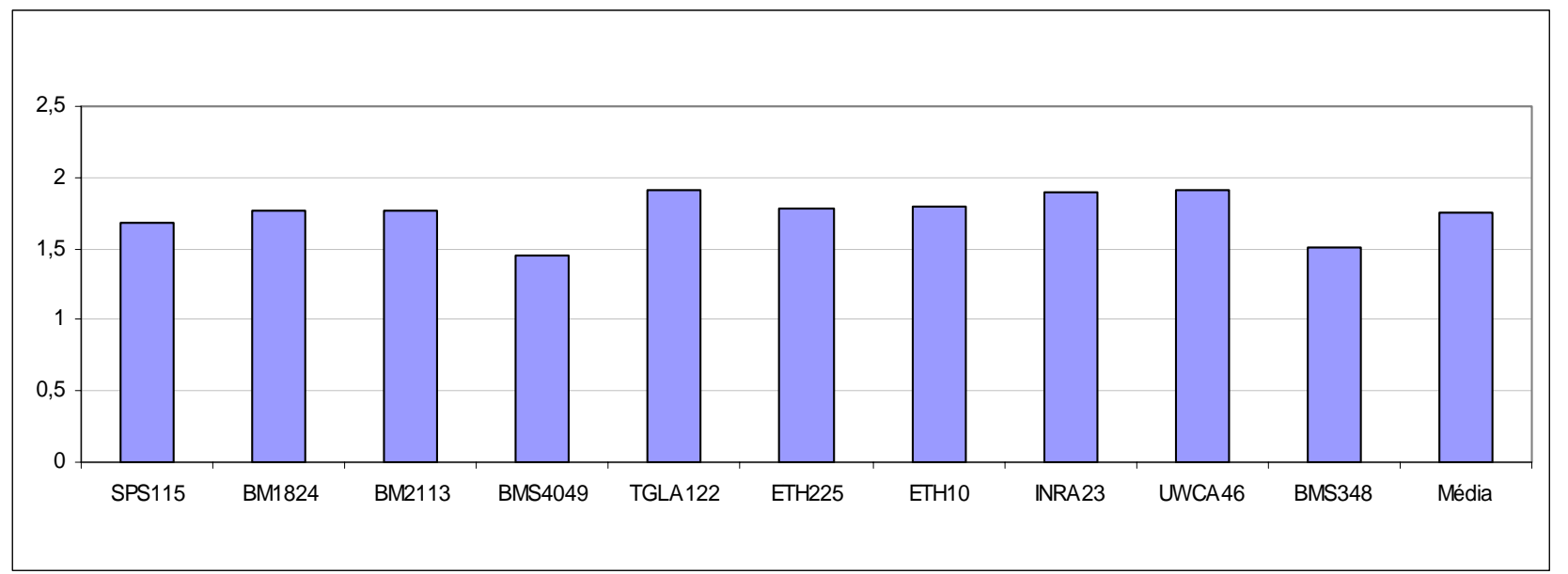

Gráfico 1. Riqueza alélica (Rs) por loco baseada numa amostra mínima de um indivíduo diplóide (2n). 
Tabela 5. Freqüências alélicas para os dez microssatélites analisados na população Pé-duro. Os alelos mais freqüentes (>20\%) aparecem destacados.

\begin{tabular}{|c|c|c|c|c|c|c|c|c|c|c|}
\hline Alelos & SPS115 & BM1824 & BM2113 & BMS4049 & TGLA122 & ЕТН225 & ЕТН10 & INRA23 & UWCA46 & BMS348 \\
\hline 2 & 0,516 & 0,316 & 0,105 & & & 0,004 & 0,096 & 0,024 & 0,020 & 0,596 \\
\hline 4 & 0,092 & 0,184 & 0,379 & 0,159 & & 0,063 & 0,072 & 0,060 & 0,087 & \\
\hline 5 & 0,136 & 0,086 & 0,153 & 0,044 & 0,012 & 0,210 & 0,200 & 0,052 & 0,095 & \\
\hline 6 & 0,080 & 0,008 & 0,024 & & & 0,075 & 0,164 & 0,077 & 0,040 & \\
\hline 9 & & & 0,012 & & 0,008 & 0,008 & 0,036 & 0,157 & 0,024 & \\
\hline 10 & & & & & 0,091 & 0,012 & 0,036 & 0,065 & 0,107 & \\
\hline 11 & & & & & 0,004 & 0,004 & 0,012 & 0,198 & 0,143 & \\
\hline
\end{tabular}




\begin{tabular}{|c|c|c|c|c|}
\hline 12 & & 0,012 & 0,113 & 0,099 \\
\hline 13 & 0,033 & & 0,040 & 0,099 \\
\hline 14 & 0,021 & & 0,008 & 0,024 \\
\hline 15 & 0,033 & & 0,008 & \\
\hline 16 & 0,004 & & & \\
\hline 17 & 0,008 & & & \\
\hline 18 & 0,083 & & & \\
\hline 19 & 0,058 & & & \\
\hline 20 & 0,190 & & & \\
\hline 21 & 0,037 & & & \\
\hline 22 & 0,120 & & & \\
\hline 23 & 0,045 & & & \\
\hline 24 & 0,066 & & & \\
\hline
\end{tabular}


Tabela 6. Heterozigose esperada (He), heterozigose observada (Ho), diversidade gênica (Hs), conteúdo de informação de polimorfismo (Pic) e valor do Fis para cada loco na população Pé-duro.

\begin{tabular}{l|ccccc}
\hline Locos & $\mathbf{( H e )}$ & $\mathbf{( H o )}$ & $\mathbf{( H s )}$ & $\mathbf{( P i c )}$ & Fis \\
\hline SPS115 & 0,687 & 0,576 & 0,688 & 0,657 & 0,162 \\
BM1824 & 0,764 & 0,762 & 0,764 & 0,722 & 0,002 \\
BM2113 & 0,772 & 0,621 & 0,772 & 0,739 & 0,195 \\
BMS4049 & 0,454 & 0,373 & 0,455 & 0,420 & 0,179 \\
TGLA122 & 0,912 & 0,661 & 0,913 & 0,902 & 0,275 \\
ETH225 & 0,780 & 0,476 & 0,781 & 0,745 & 0,390 \\
ETH10 & 0,880 & 0,672 & 0,880 & 0,864 & 0,237 \\
INRA23 & 0,896 & 0,596 & 0,898 & 0,884 & 0,334 \\
UWCA46 & 0,911 & 0,801 & 0,913 & 0,901 & 0,121 \\
BMS348 & 0,502 & 0,464 & 0,502 & 0,397 & 0,075 \\
\hline Valor médio & $\mathbf{0 , 7 5 5}$ & $\mathbf{0 , 6 0 0}$ & $\mathbf{0 , 7 5 6}$ & $\mathbf{0 , 7 2 3}$ & $\mathbf{0 , 2 0 6 *}$ \\
\hline
\end{tabular}




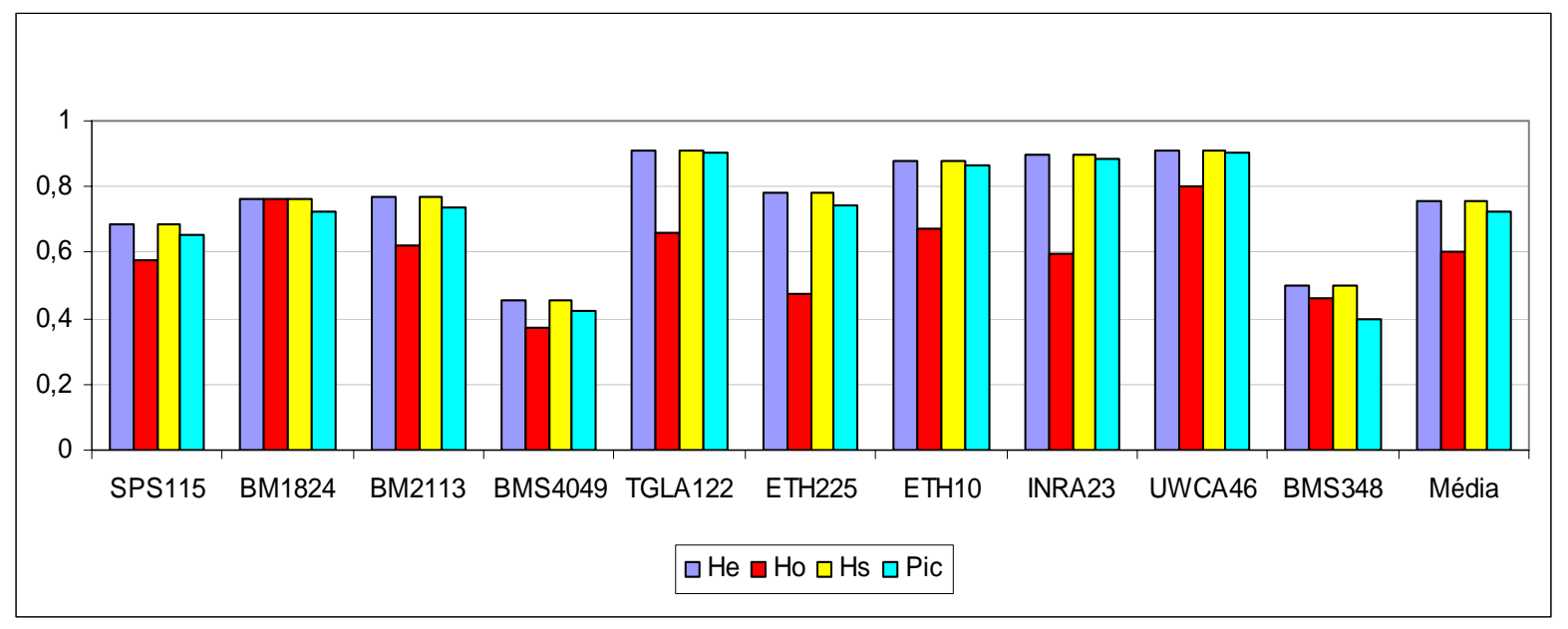

Gráfico 2. Heterozigose esperada (He), heterozigose observada (Ho), diversidade gênica (Hs) e conteúdo de informação de polimorfismo (Pic) para cada loco na população Pé-duro.

Tabela 7. Coeficiente de endogamia Fis para todos os locos analisados.

\begin{tabular}{ll}
\hline \multicolumn{2}{c}{ Coeficiente de Endogamia } \\
\hline Intervalo de confiança 95\% & 0,134 / 0,269 \\
Intervalo de confiança 99\% & 0,109 / 0,298* \\
Valor de Fis & $0,206^{*}$ \\
\hline$* \mathrm{P}<0,01$ &
\end{tabular}




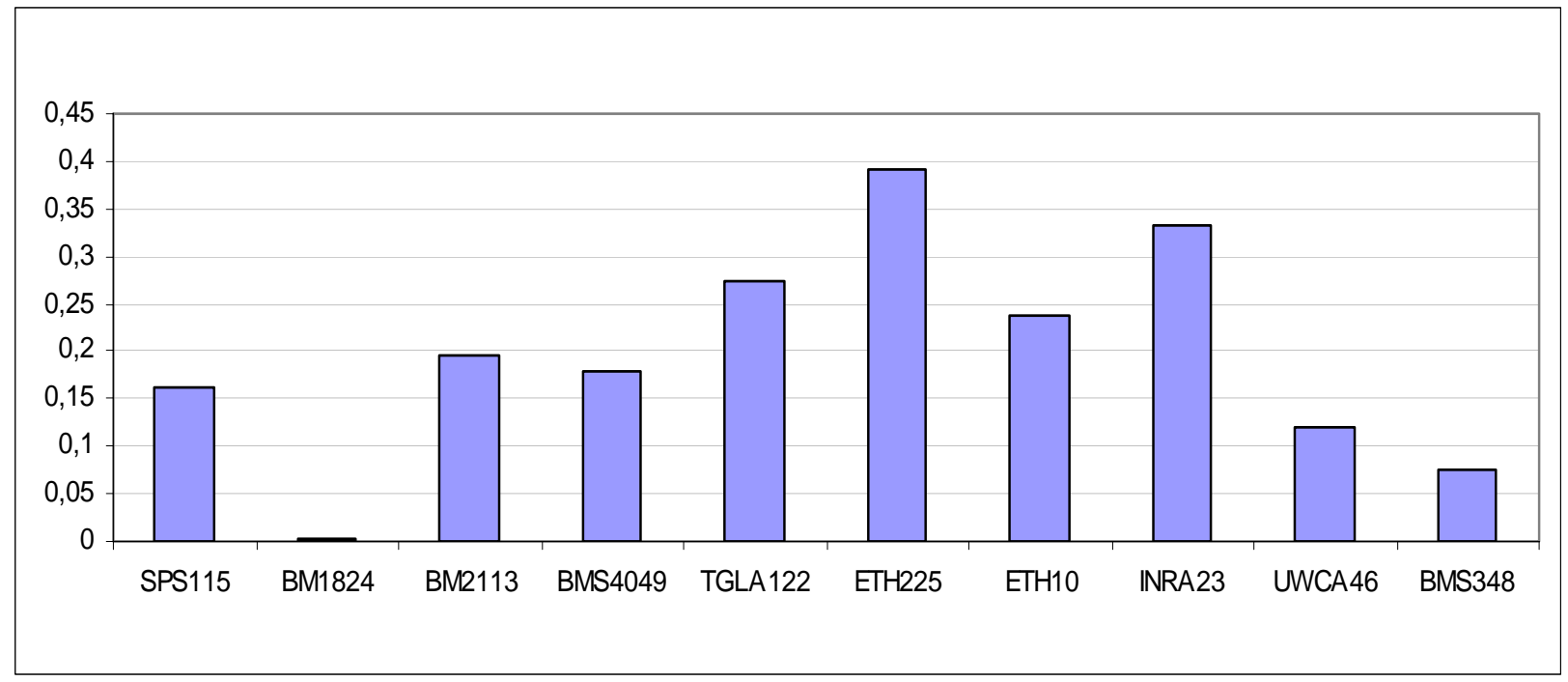

Gráfico 3. Coeficiente de endogamia Fis para todos os locos analisados. 
Tabela 8. Probabilidade obtida com o teste exato e déficit de heterozigotos para verificação do Equilíbrio de Hardy-Weinberg pelo método de Fisher para cada loco na população Pé-duro.

\begin{tabular}{|c|c|c|c|c|}
\hline Locos & $\begin{array}{l}\text { Teste exato } \\
\text { Hardy-Weinberg } \\
\text { (valor de } P \text { ) }\end{array}$ & Erro Padrão & $\begin{array}{l}\text { Teste déficit de } \\
\text { heterozigotos } \\
\text { Hardy-Weinberg } \\
\text { (valor de } P \text { ) }\end{array}$ & Erro padrão \\
\hline SPS115 & $0,0000 *$ & 0,0000 & $0,0063^{*}$ & 0,0013 \\
\hline BM1824 & $0,0026 *$ & 0,0009 & 0,1994 & 0,0149 \\
\hline BM2113 & $0,0000 *$ & 0,0002 & $0,0029 *$ & 0,0052 \\
\hline BMS4049 & $0,0002 *$ & 0,0000 & 0,0566 & 0,0000 \\
\hline TGLA122 & $0,0000^{*}$ & 0,0000 & $0,0000^{*}$ & 0,0014 \\
\hline ЕTH225 & $0,0000 *$ & 0,0000 & $0,0000 *$ & 0,0000 \\
\hline ETH10 & $0,0000^{*}$ & 0,0000 & $0,0000^{*}$ & 0,0000 \\
\hline INRA23 & $0,0000 *$ & 0,0000 & $0,0000^{*}$ & 0,0000 \\
\hline UWCA46 & $0,0000^{*}$ & 0,0000 & $0,0003^{*}$ & 0,0002 \\
\hline BMS348 & 0,1206 & 0,0052 & 0,2655 & 0,0118 \\
\hline
\end{tabular}

*Desvio significativo $(\mathrm{P}<0,05)$. 
Tabela 9. Diversidade gênica (Hs) por loco e por população.

\begin{tabular}{l|l|l|l|l|l|l|l|l}
\hline & SPS115 & BM1824 & BM2113 & TGLA122 & ETH225 & ETH10 & INRA23 & Média \\
\hline $\begin{array}{l}\text { Pé-duro } \\
\text { n=126 }\end{array}$ & 0,688 & 0,764 & 0,772 & 0,913 & 0,781 & 0,880 & 0,898 & 0,813 \\
\hline $\begin{array}{l}\text { Casanare } \\
\mathrm{n}=54\end{array}$ & 0,684 & 0,686 & & 0,822 & & 0,848 & 0,763 & 0,760 \\
\hline $\begin{array}{l}\text { Asiático } \\
\mathrm{n}=182\end{array}$ & & 0,602 & 0,704 & 0,770 & 0,623 & 0,584 & 0,677 & 0,660 \\
\hline $\begin{array}{l}\text { Uruguaio } \\
\mathrm{n}=19\end{array}$ & & & 0,755 & & & 0,580 & & 0,667 \\
\hline $\begin{array}{l}\text { Nativo } \\
\text { Jersey } \\
\mathrm{n}=199\end{array}$ & & & 0,653 & 0,657 & 0,598 & 0,624 & & 0,633 \\
\hline $\begin{array}{l}\text { Nativo } \\
\text { Europeu } \\
\mathrm{n}=899\end{array}$ & & & & & 0,736 & 0,729 & 0,776 & 0,747 \\
\hline
\end{tabular}

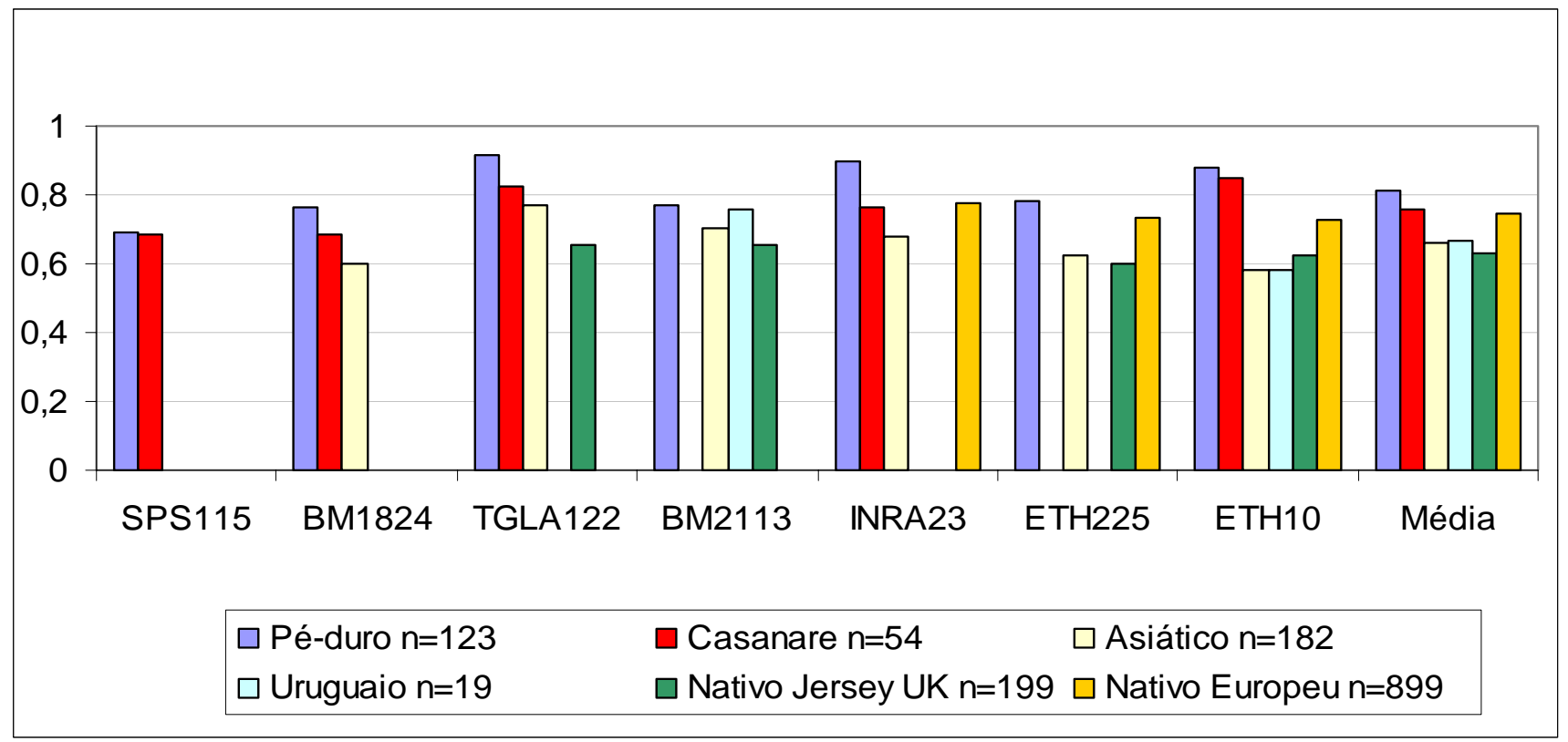

Gráfico 4. Gráfico comparativo de diversidade gênica (Hs) por loco e por população. 


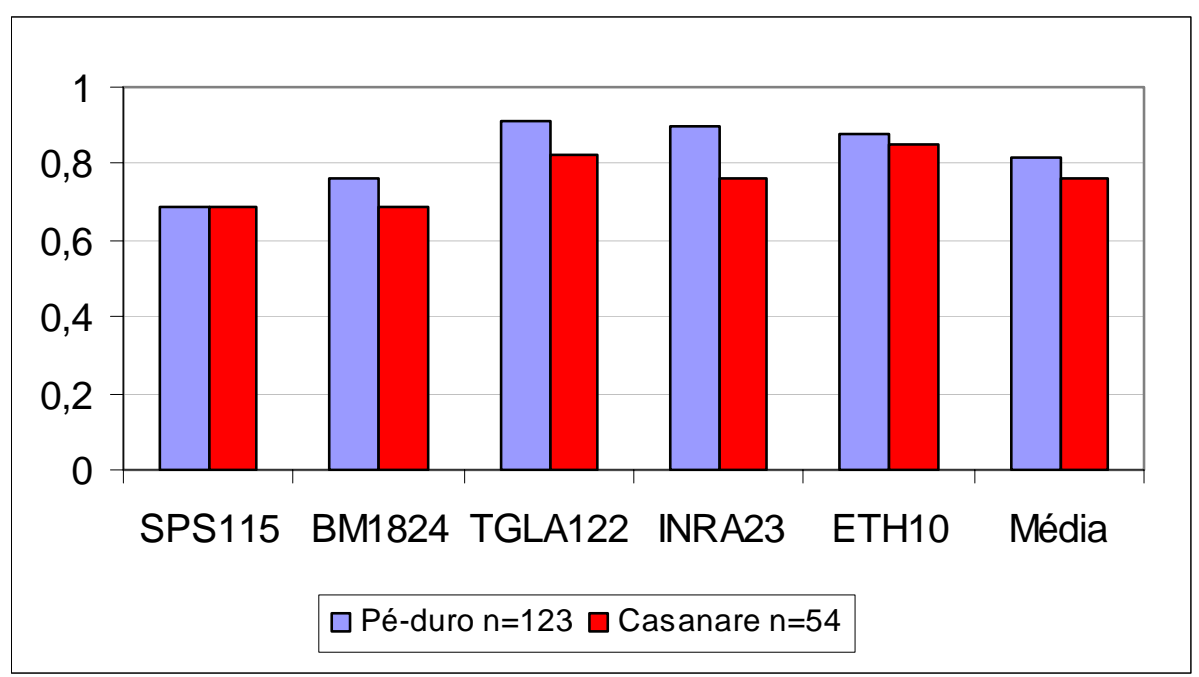

Gráfico 5. Gráfico comparativo de diversidade gênica (Hs) por loco entre Pé-duro e a raça crioula Casanare da Colômbia.

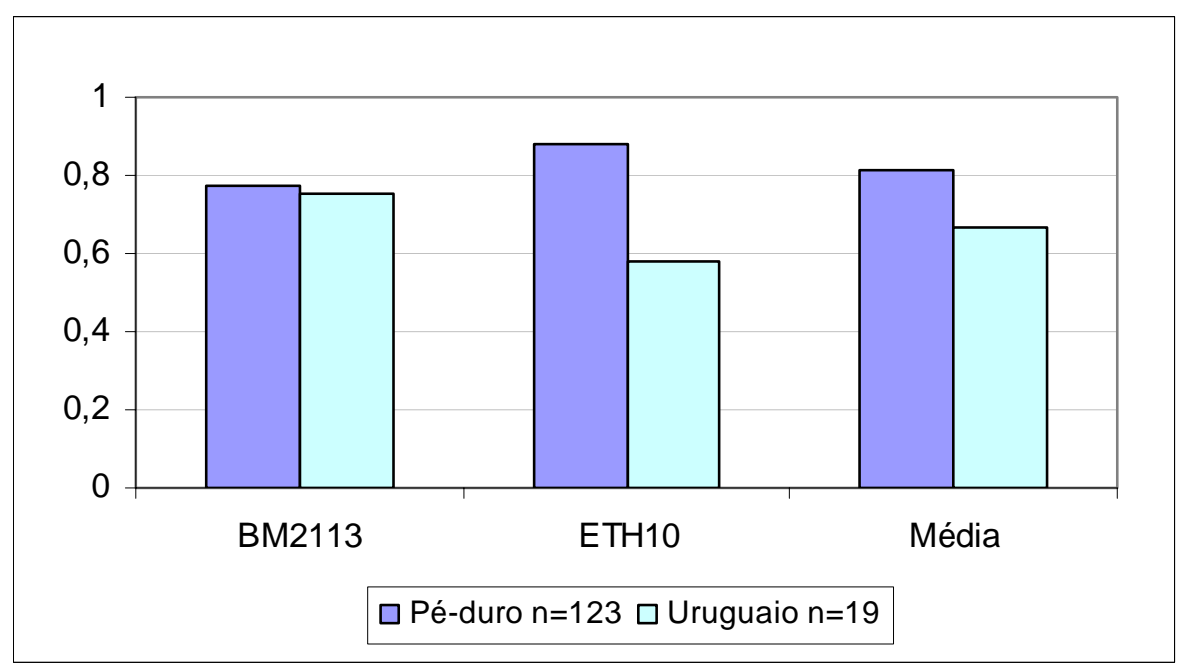

Gráfico 6. Gráfico comparativo de diversidade gênica (Hs)

por loco entre Pé-duro e a raça crioula do Uruguai. 


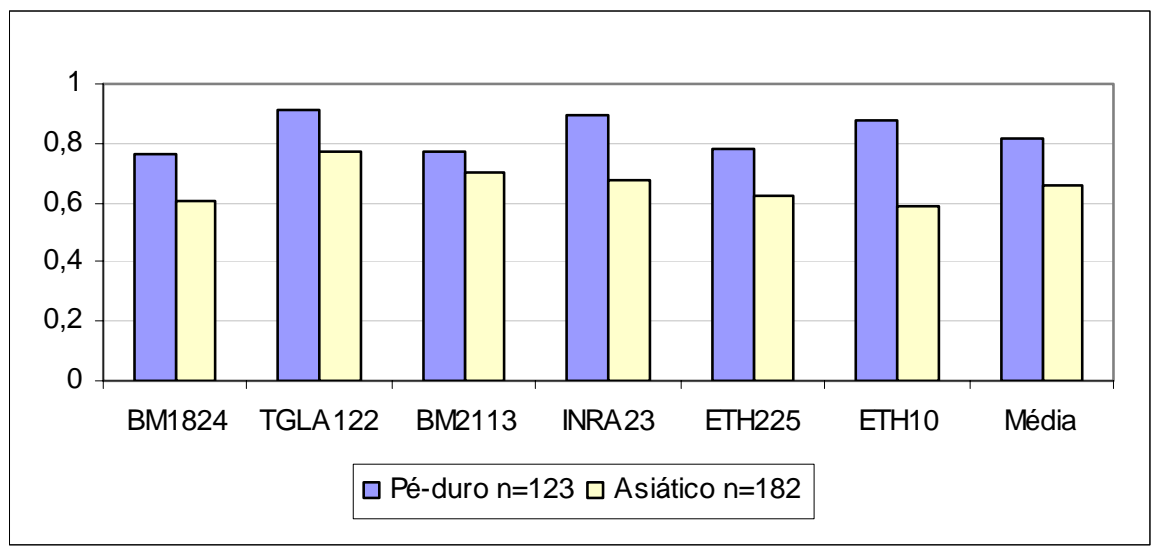

Gráfico 7. Gráfico comparativo de diversidade gênica

(Hs) por loco entre Pé-duro e raças nativas Asiáticas.

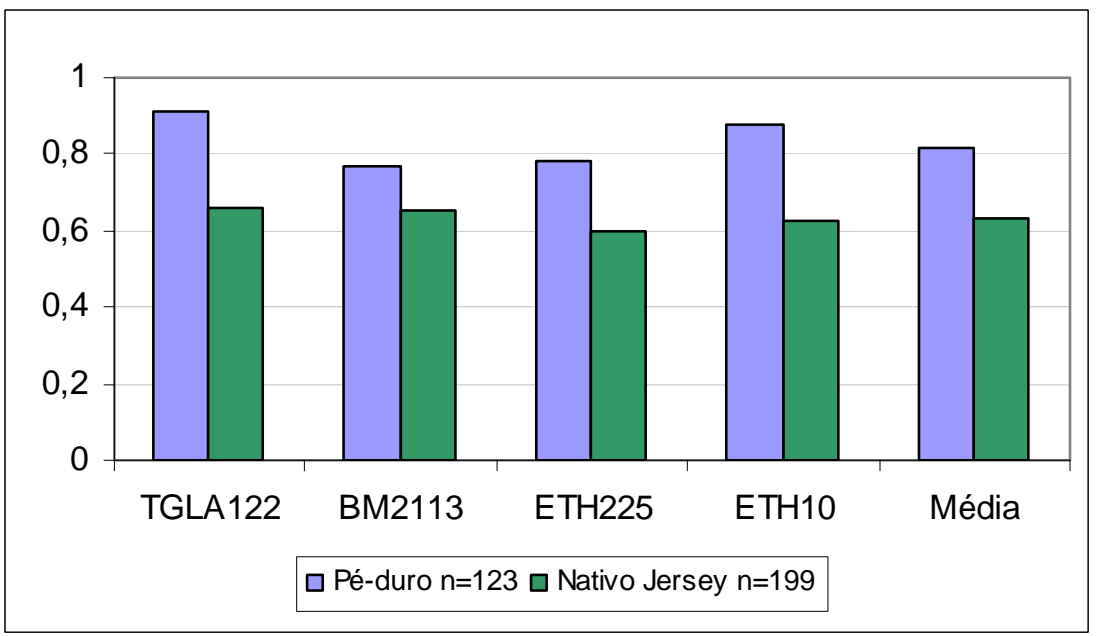

Gráfico 8. Gráfico comparativo de diversidade gênica

(Hs) por loco entre Pé-duro e raça nativa Jersey do Reino Unido. 


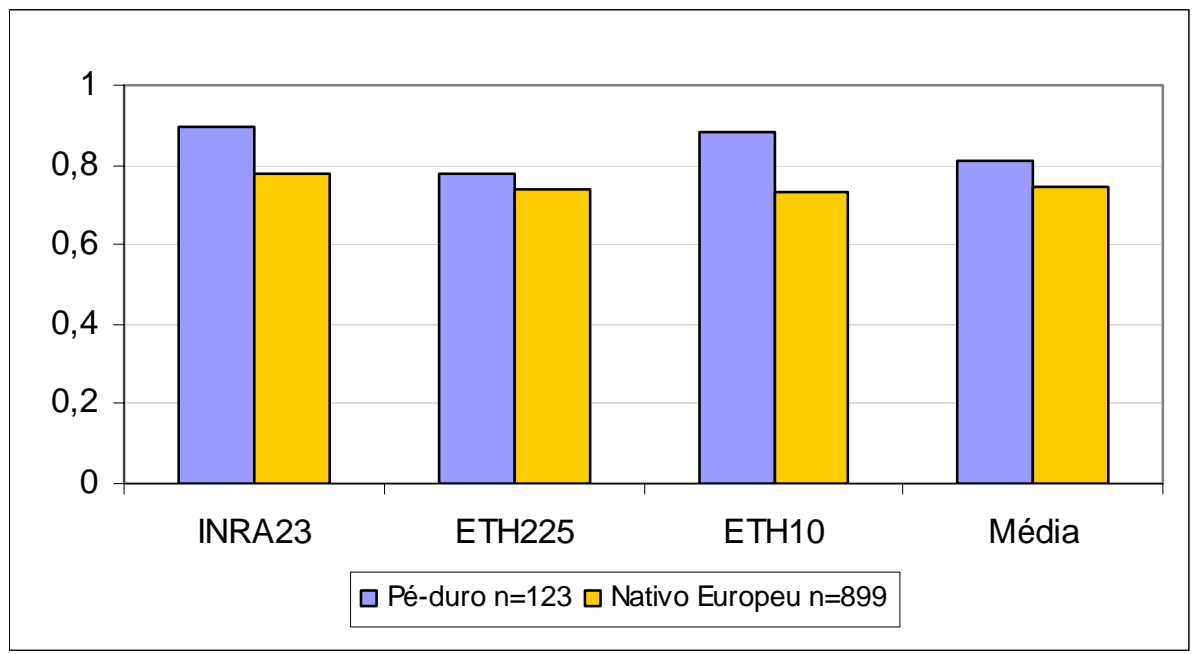

Gráfico 9. Gráfico comparativo de diversidade gênica (Hs) por loco entre Pé-duro e raças nativas da Europa.

Tabela 10. Número de alelos (Na) amostrados por loco e por população.

\begin{tabular}{l|l|l|l|l|l|l|l|l}
\hline & SPS115 & BM1824 & BM2113 & TGLA122 & ETH225 & ETH10 & INRA23 & Média \\
\hline $\begin{array}{l}\text { Pé-duro } \\
\mathrm{n}=126\end{array}$ & 6 & 6 & 9 & 20 & 11 & 12 & 15 & 11,3 \\
\hline $\begin{array}{l}\text { Casanare } \\
\mathrm{n}=54\end{array}$ & 7 & 5 & & 11 & & 8 & 10 & 8,2 \\
\hline $\begin{array}{l}\text { Nativo } \\
\text { Português } \\
\mathrm{n}=470\end{array}$ & 8 & 7 & 11 & 19 & 10 & 11 & & 11 \\
\hline $\begin{array}{l}\text { Uruguaio } \\
\mathrm{n}=19\end{array}$ & & & 6 & & & 3 & & 4,5 \\
\hline $\begin{array}{l}\text { Nativo } \\
\text { Jersey } \\
\mathrm{n}=199\end{array}$ & & 5 & 5 & 3 & 5 & & 4,5 \\
\hline
\end{tabular}




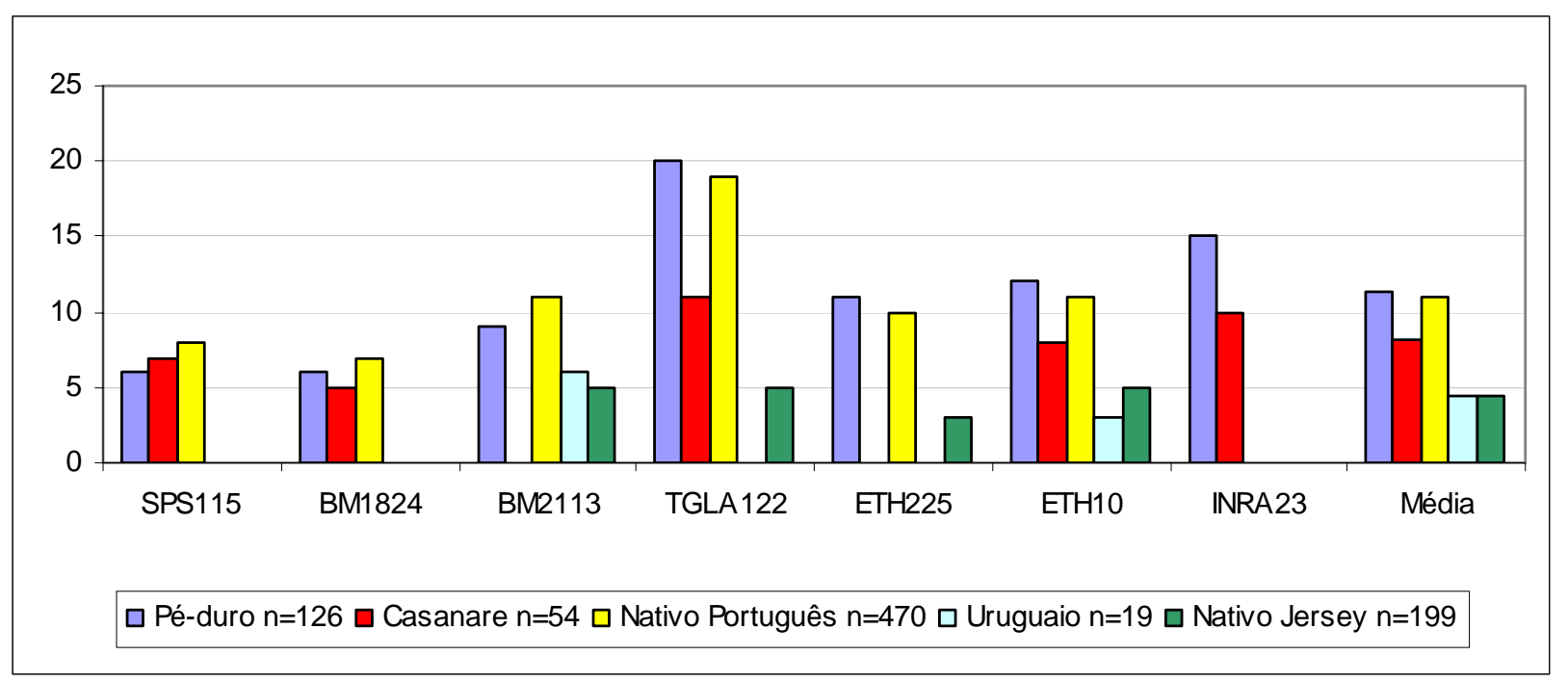

Gráfico 10. Gráfico comparativo do número de alelos (Na) amostrados por loco e população.

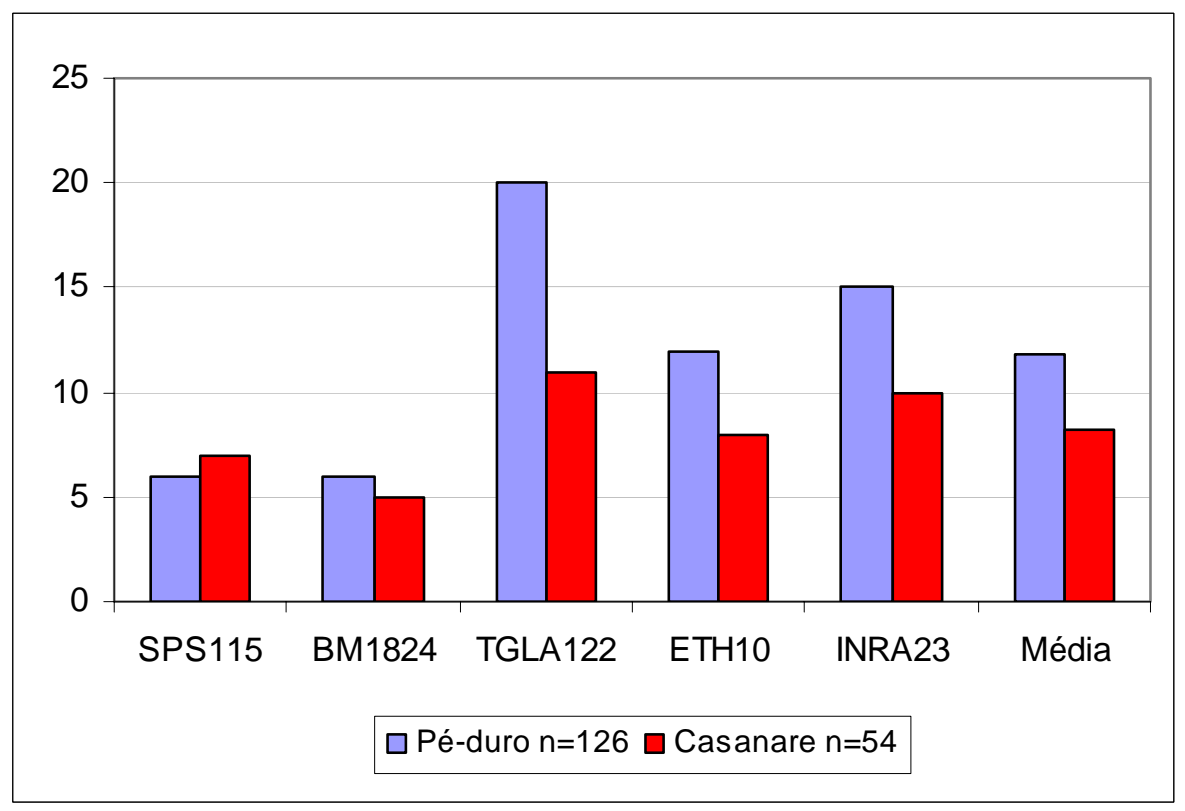

Gráfico 11. Gráfico comparativo do número de alelos (Na) amostrados por loco entre Pé-duro e Casanare da Colômbia. 


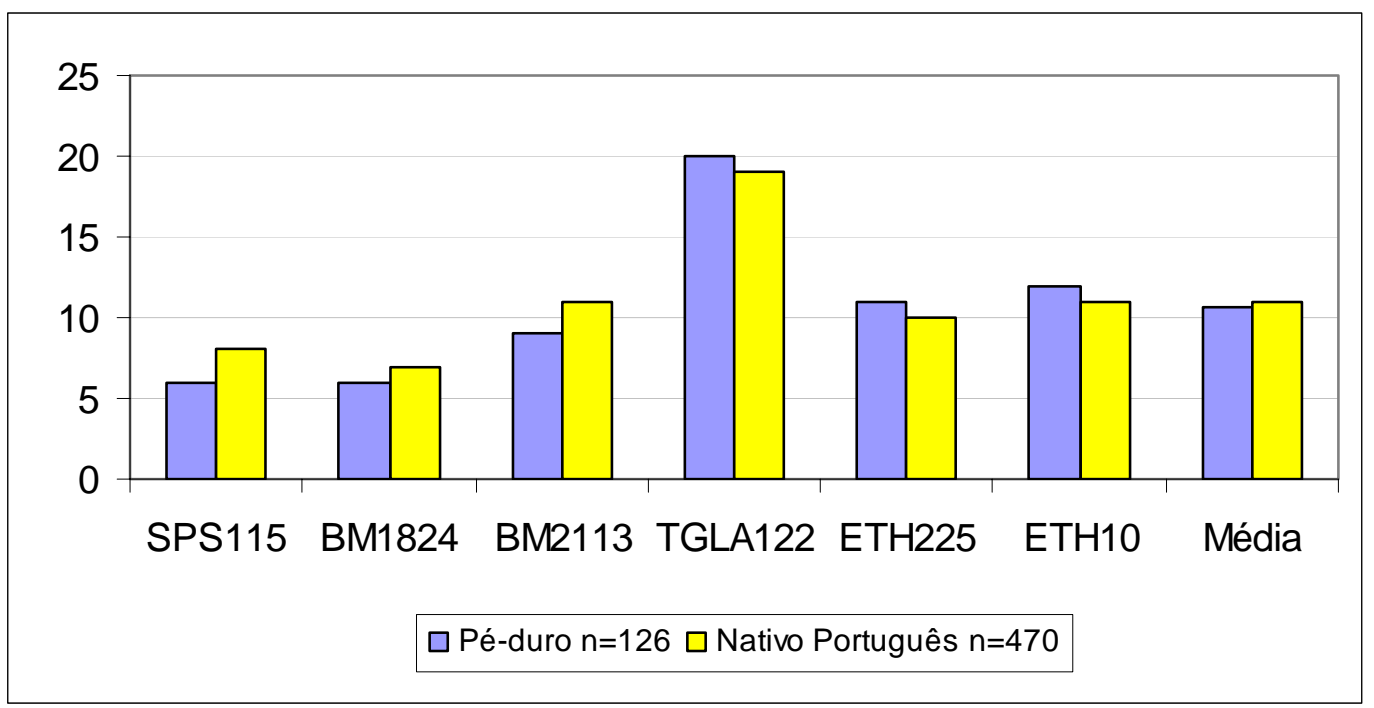

Gráfico 12. Gráfico comparativo do número de alelos (Na) amostrados por loco entre Pé-duro e raças nativas de Portugal.

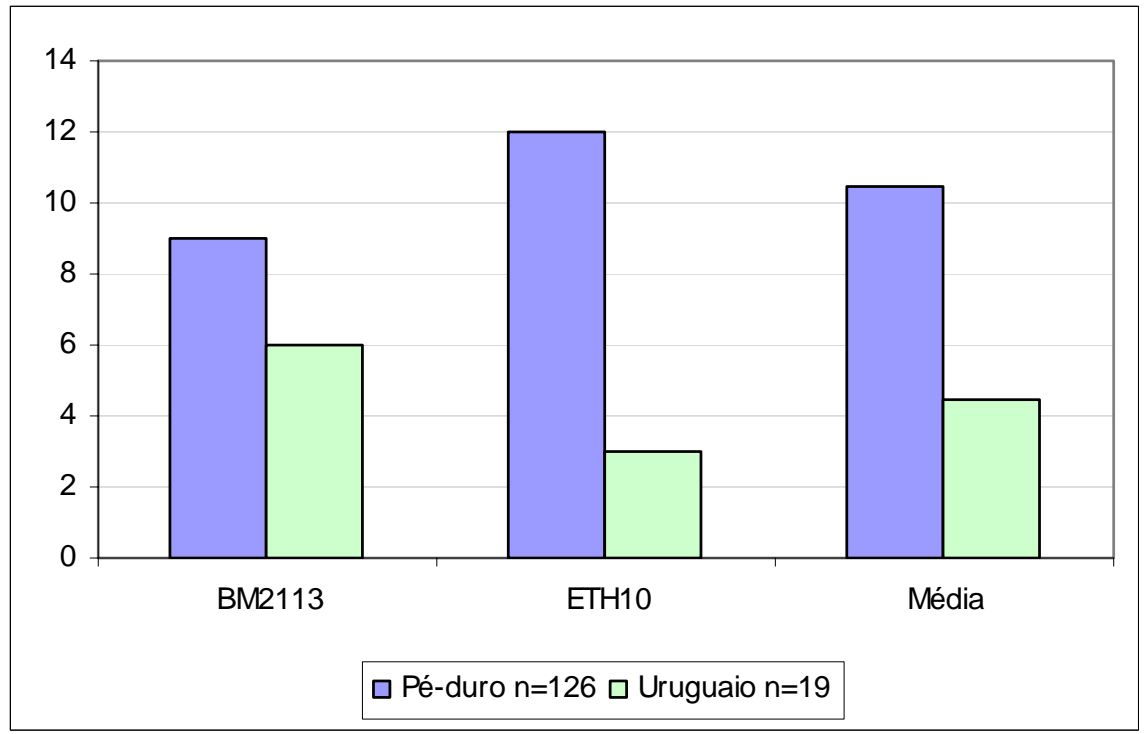

Gráfico 13. Gráfico comparativo do número de alelos (Na) amostrados por loco entre Pé-duro e crioulo do Uruguai. 


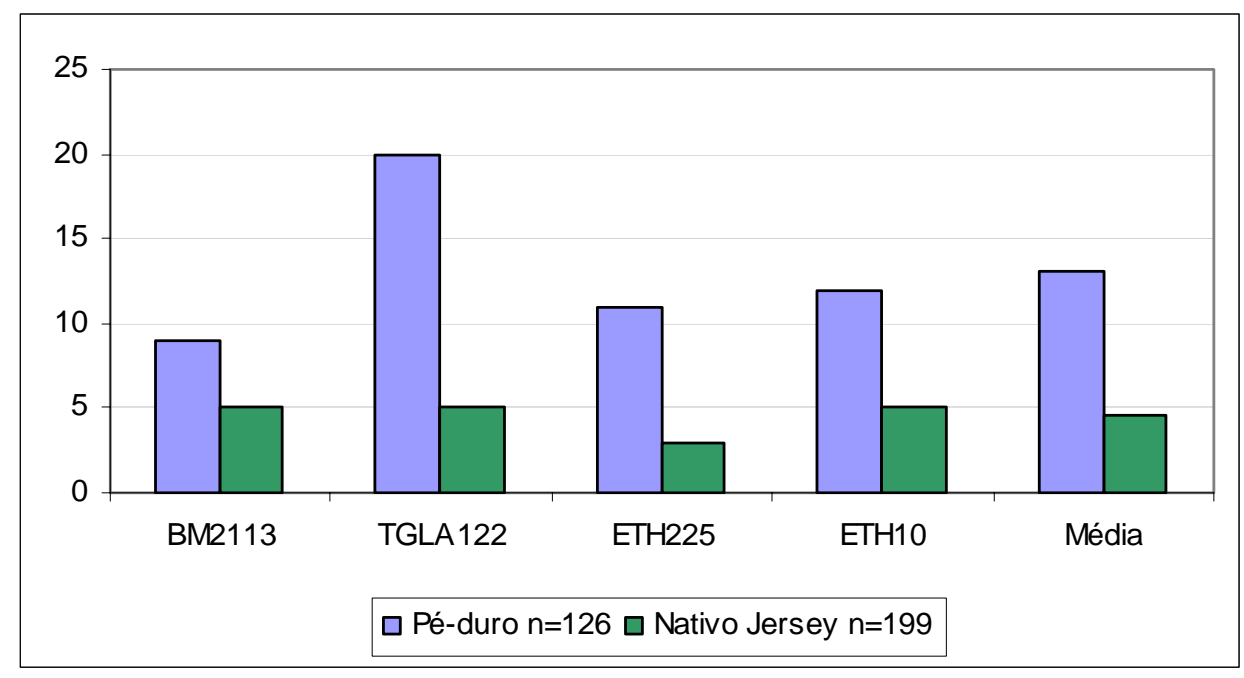

Gráfico 14. Gráfico comparativo do número de alelos (Na) amostrados por loco entre Pé-duro e a raça nativa Jersey do Reino Unido.

Tabela 11. Heterozigose observada (Ho) por loco e por população.

\begin{tabular}{l|l|l|l|l|l|l|l|l}
\hline & SPS115 & BM1824 & BM2113 & TGLA122 & ETH225 & ETH10 & INRA23 & Média \\
\hline $\begin{array}{l}\text { Pé-duro } \\
\mathrm{n}=126\end{array}$ & 0,576 & 0,762 & 0,621 & 0,661 & 0,476 & 0,672 & 0,596 & 0,623 \\
\hline $\begin{array}{l}\text { Casanare } \\
\mathrm{n}=54\end{array}$ & 0,738 & 0,695 & & 0,927 & & 0,807 & 0,602 & 0,753 \\
\hline $\begin{array}{l}\text { Uruguaio } \\
\mathrm{n}=19\end{array}$ & & & 0,788 & & & 0,563 & & 0,675 \\
\hline $\begin{array}{l}\text { Nativo } \\
\text { Jersey } \\
\mathrm{n}=199\end{array}$ & & & 0,654 & 0,713 & 0,609 & 0,690 & & 0,666 \\
\hline
\end{tabular}




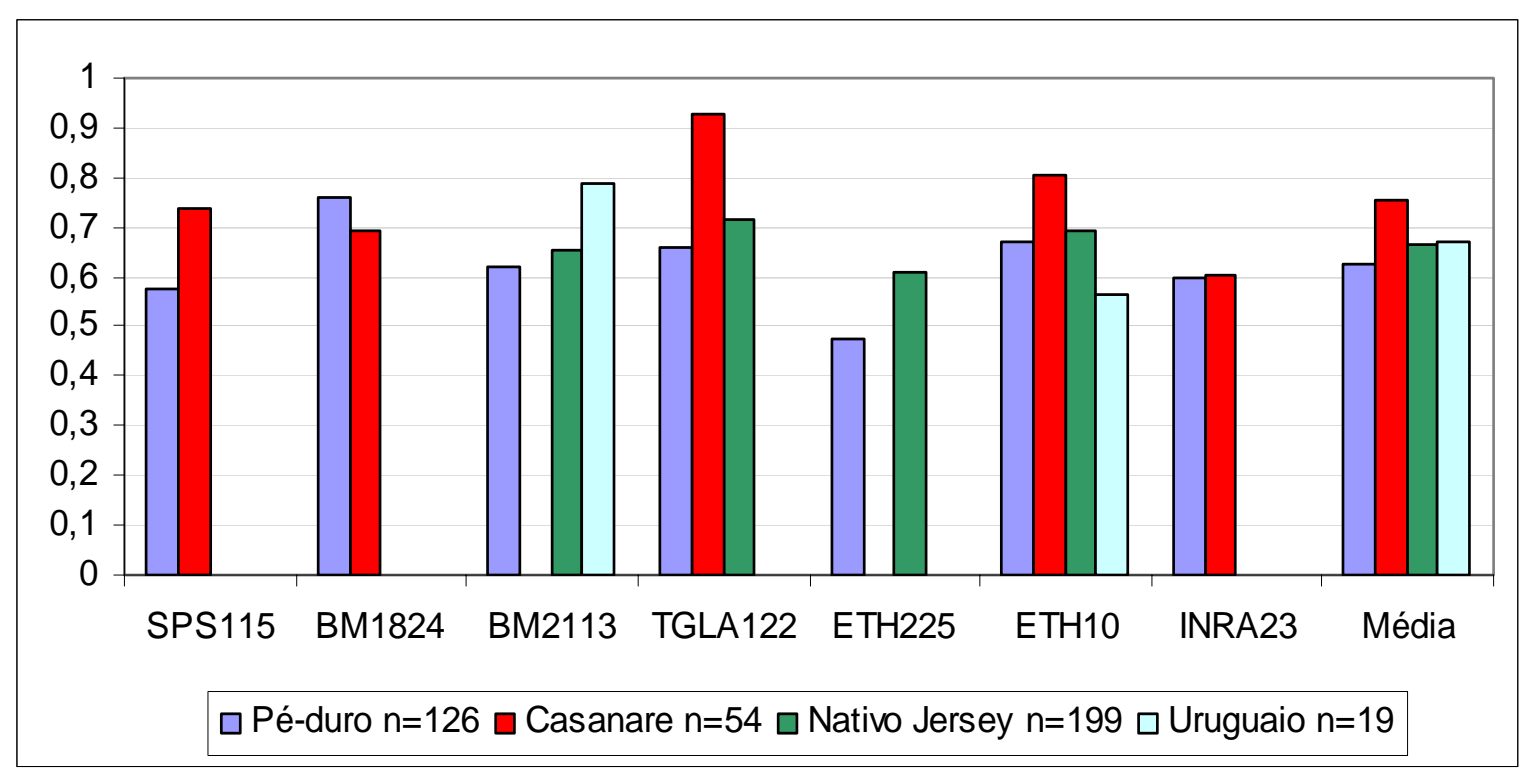

Gráfico 15. Gráfico comparativo de heterozigose observada (Ho) por loco e população.

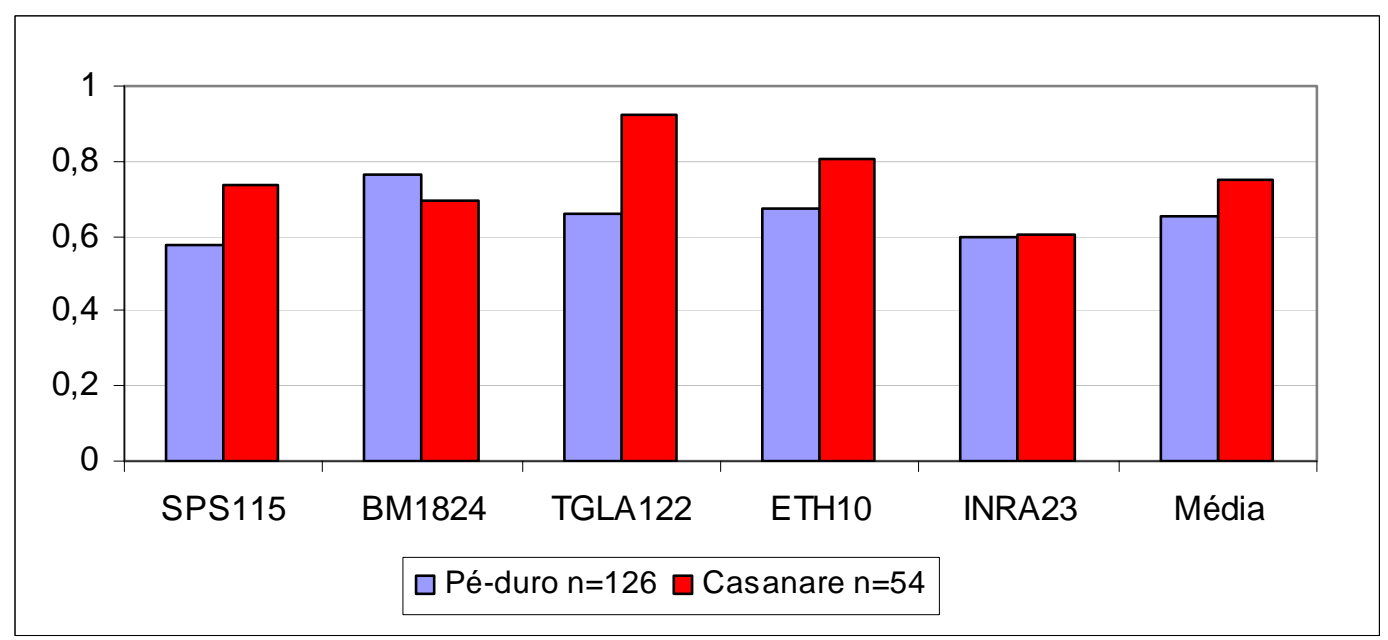

Gráfico 16. Gráfico comparativo de heterozigose observada (Ho) por loco entre Pé-duro e Casanare da Colômbia. 


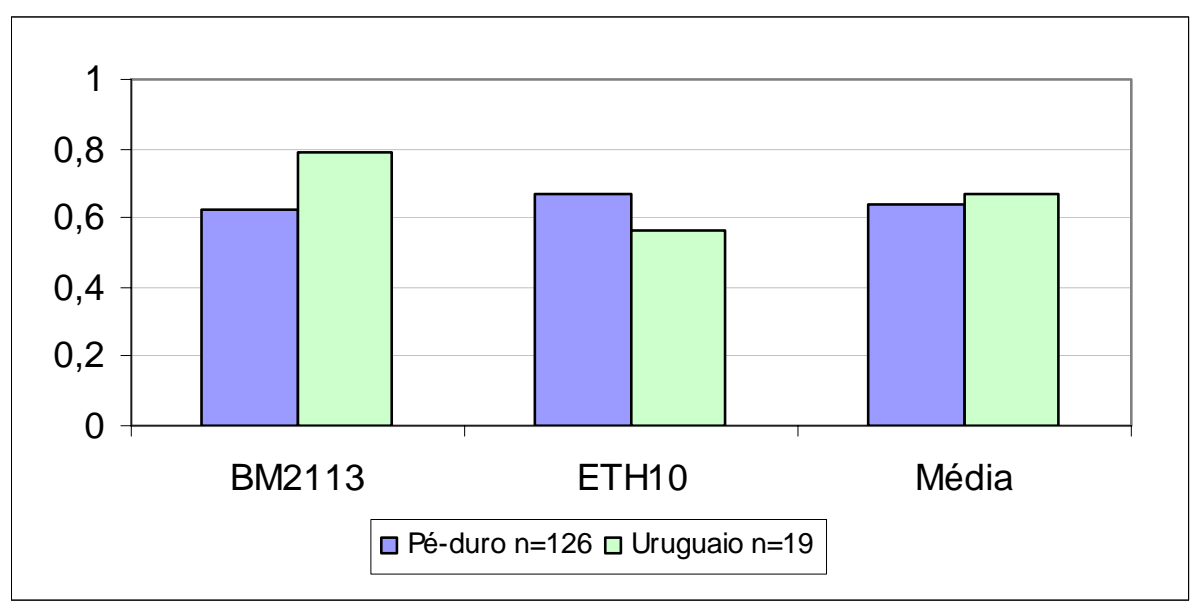

Gráfico 17. Gráfico comparativo de heterozigose observada (Ho) por loco entre Pé-duro e crioulo do Uruguai.

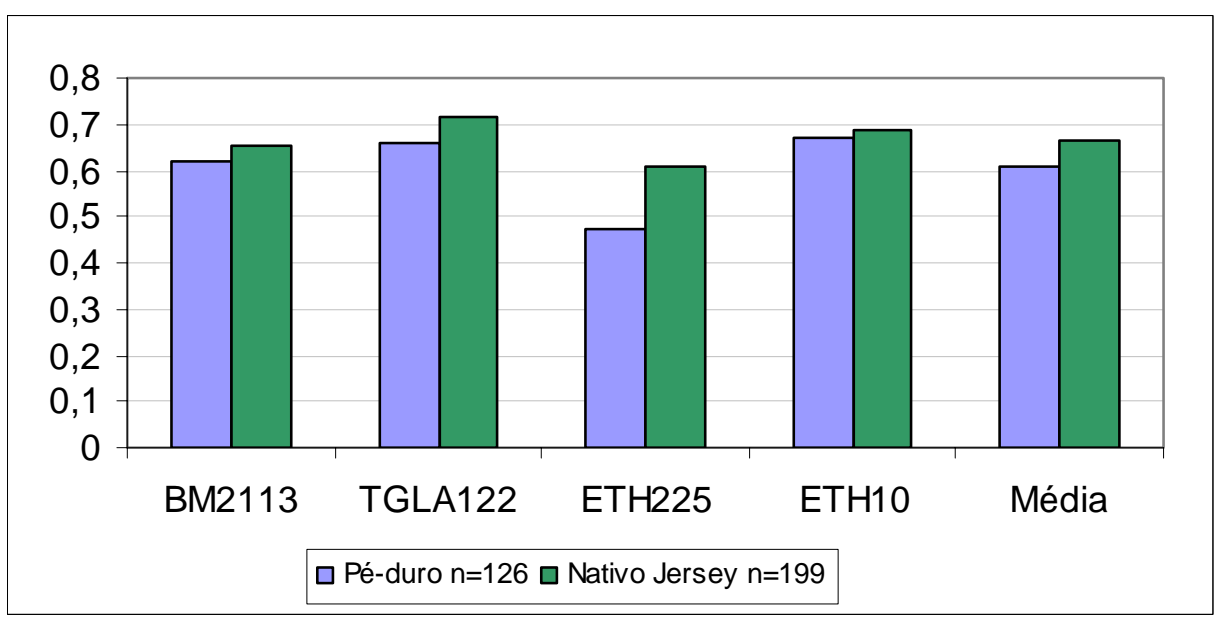

Gráfico 18. Gráfico comparativo de heterozigose observada (Ho) por loco entre Pé-duro e a raça nativa Jersey do Reino Unido. 
Tabela 12. Coeficiente de endogamia Fis por loco e por população.

\begin{tabular}{l|l|l|l|l|l|l|l}
\hline & SPS115 & BM1824 & BM2113 & TGLA122 & ETH225 & ETH10 & INRA23 \\
\hline $\begin{array}{l}\text { Pé-duro } \\
\mathrm{n}=126\end{array}$ & 0,162 & 0,002 & 0,195 & 0,275 & 0,390 & 0,237 & 0,334 \\
\hline $\begin{array}{l}\text { Casanare } \\
\mathrm{n}=54\end{array}$ & 0,100 & $-0,155$ & & $-0,079$ & & 0,039 & 0,054 \\
\hline $\begin{array}{l}\text { Nativo } \\
\text { Europeu } \\
\mathrm{n}=899\end{array}$ & 0,118 & 0,020 & 0,007 & $-0,003$ & & 0,006 & 0,071 \\
\hline $\begin{array}{l}\text { Alberes } \\
\text { Catalunha } \\
\text { Espanha } \\
\mathrm{n}=82\end{array}$ & 0,000 & 0,081 & $-0,079$ & 0,147 & $-0,038$ & $-0,010$ & $-0,001$ \\
\hline $\begin{array}{l}\text { Africano } \\
\text { Namchi } \\
\mathrm{n}=30\end{array}$ & 0,000 & $-0,091$ & $-0,119$ & $-0,410$ & & 0,100 & 0,181 \\
\hline $\begin{array}{l}\text { Africano } \\
\text { Muturu } \\
\mathrm{n}=20\end{array}$ & 0,000 & $-0,152$ & $-0,063$ & $-0,007$ & & 0,058 & $-0,004$ \\
\hline $\begin{array}{l}\text { Africano } \\
\text { N'Dama } \\
\mathrm{n}=26\end{array}$ & 0,120 & -158 & 0,351 \\
\hline
\end{tabular}




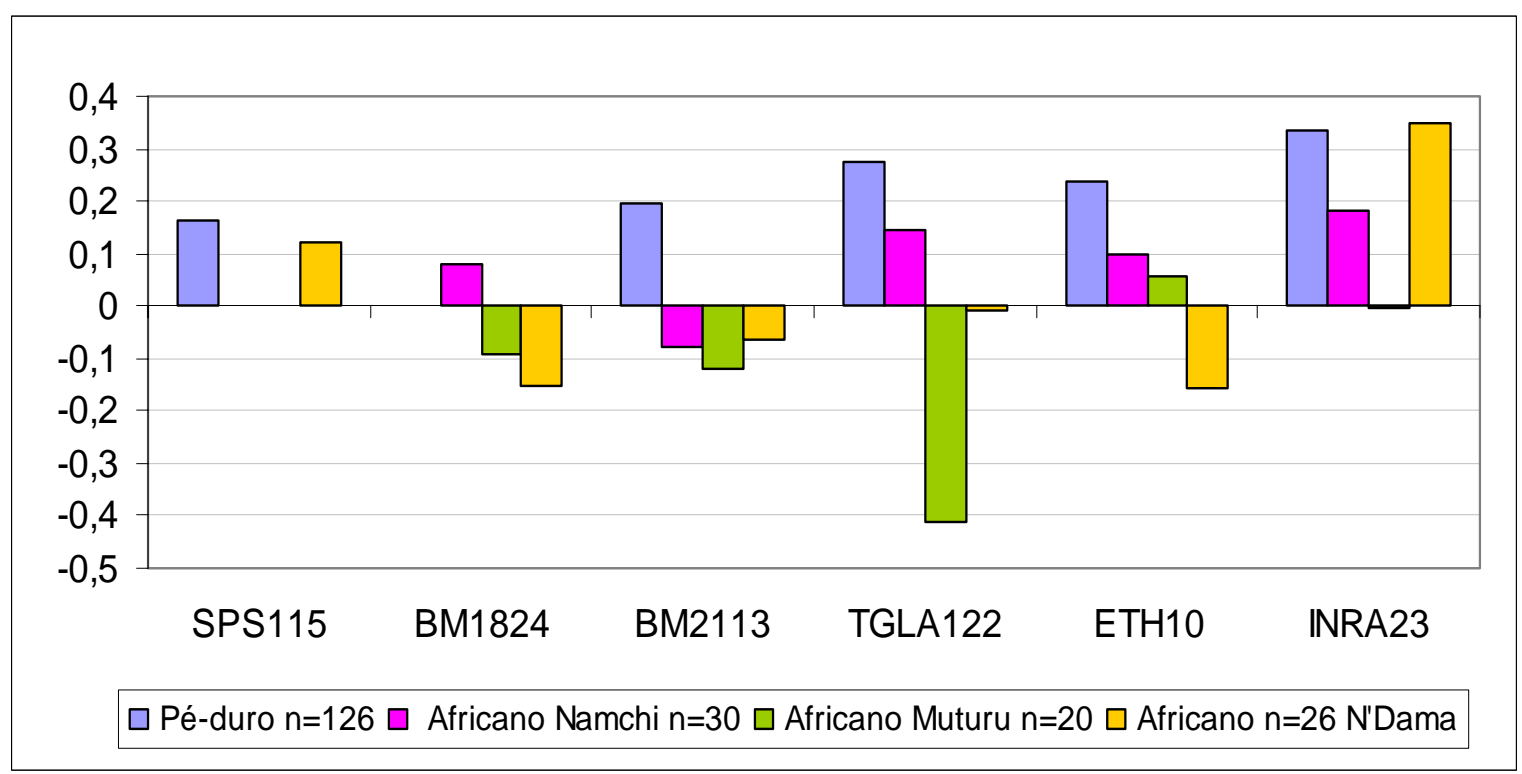

Gráfico 19. Gráfico comparativo do coeficiente de endogamia Fis por loco entre Pé-duro e raças nativas da África.

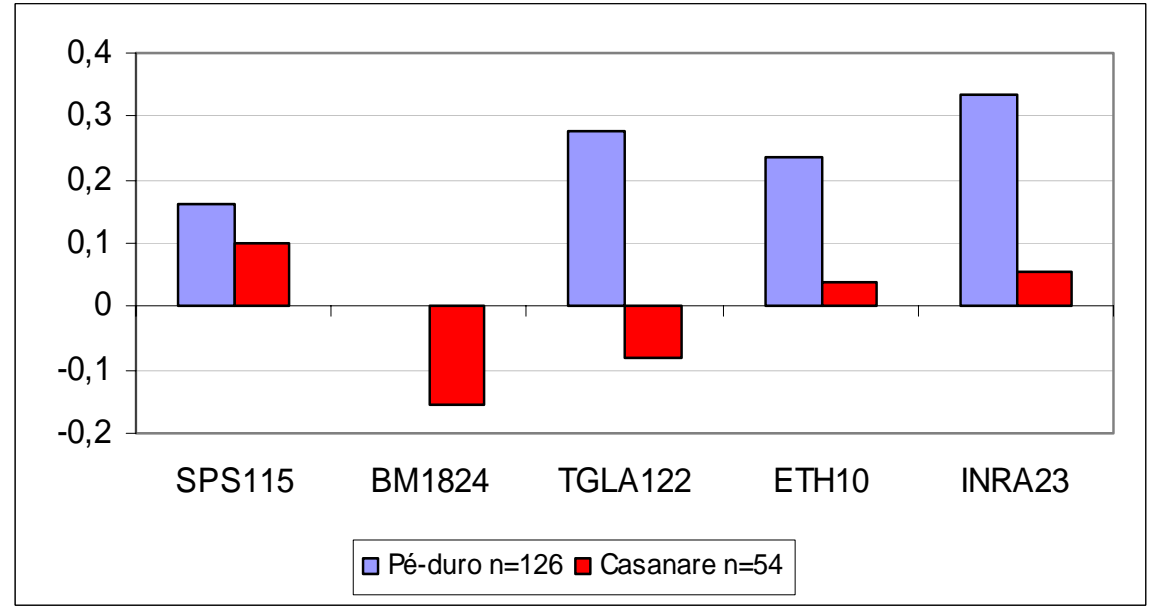

Gráfico 20. Gráfico comparativo do coeficiente de endogamia Fis por loco entre Pé-duro e Casanare da Colômbia. 


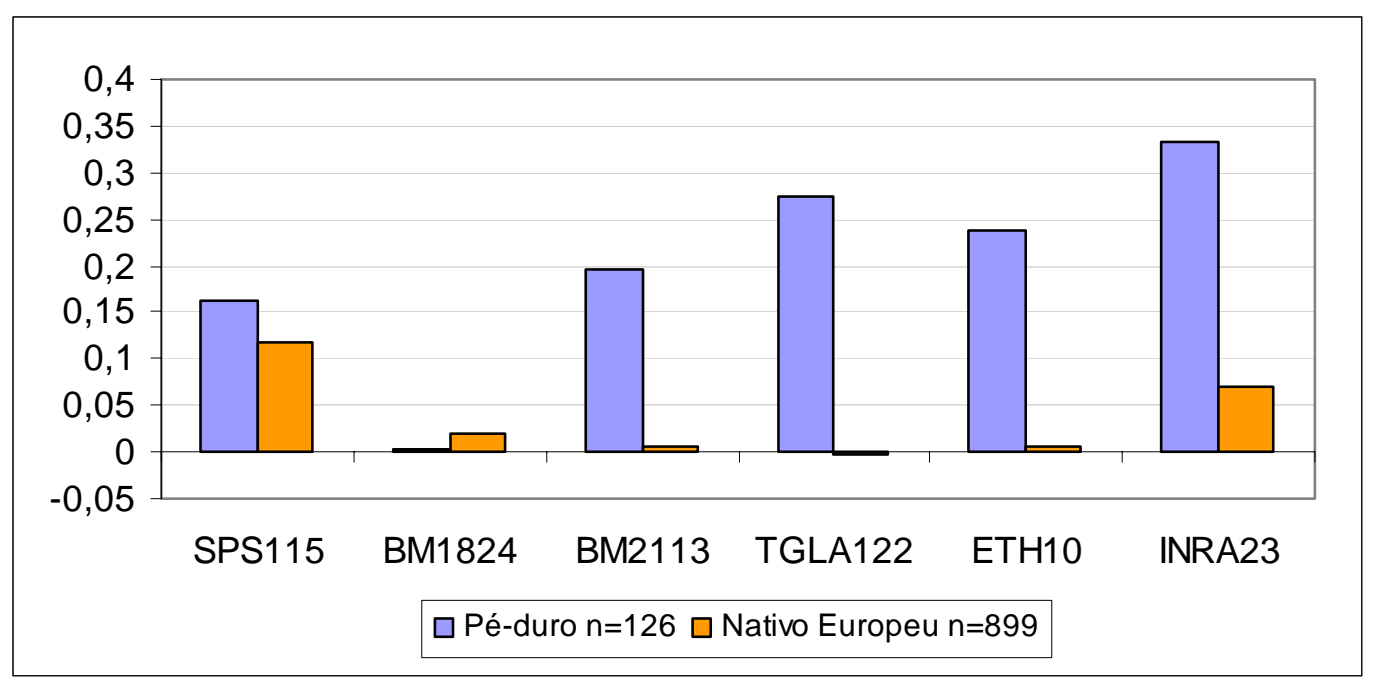

Gráfico 21. Gráfico comparativo do coeficiente de endogamia Fis por loco entre Pé-duro e raças nativas da Europa.

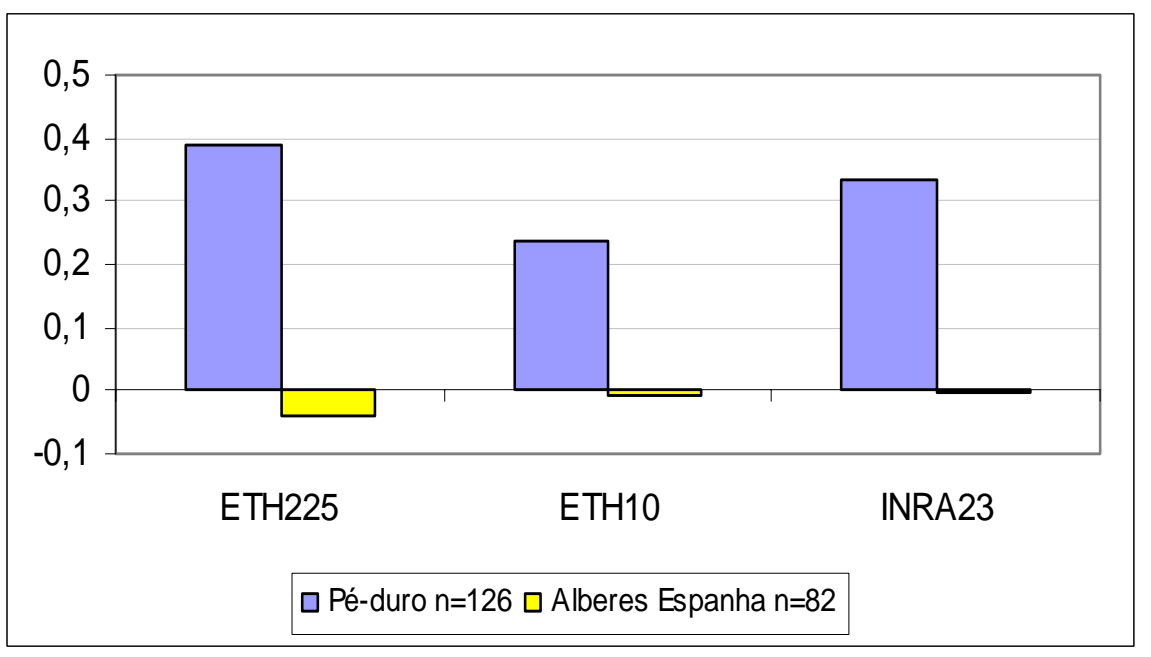

Gráfico 22. Gráfico comparativo do coeficiente de endogamia

Fis por loco entre Pé-duro e a raça nativa Alberes da Catalunha, Espanha. 
Tabela 13. Riqueza alélica por loco entre Pé-duro e a raça crioula Casanare da Colômbia.

\begin{tabular}{l|l|l|l|l|l|l}
\hline & SPS115 & BM1824 & TGLA122 & ETH10 & INRA23 & Média \\
\hline $\begin{array}{l}\text { Pé-duro } \\
\mathrm{n}=126 \\
(\mathrm{n}=1)^{*}\end{array}$ & 1,688 & 1,764 & 1,912 & 1,789 & 1,897 & 1,81 \\
\hline $\begin{array}{c}\text { Casanare } \\
(\mathrm{n}=1)^{*}\end{array}$ & 1,683 & 1,687 & 1,823 & 1,847 & 1,763 & 1,76 \\
\hline
\end{tabular}

* Rs por loco baseada numa amostra mínima de um indivíduo diplóide.

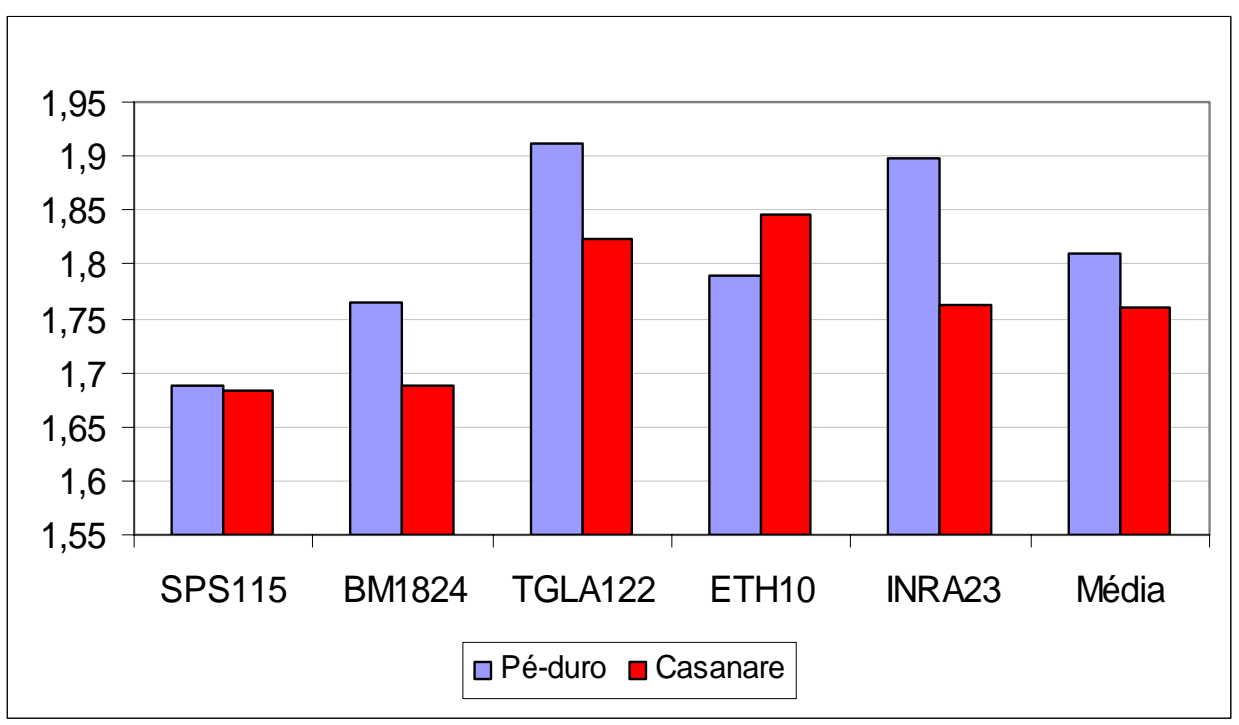

Gráfico 23. Gráfico comparativo de riqueza alélica por loco entre Pé-duro e a raça crioula Casanare da Colômbia. 
Tabela 15. Valores comparativos do número de alelos (Na) amostrados por loco entre Pé-duro (Bos taurus) e raças nativas da Índia (Bos indicus).

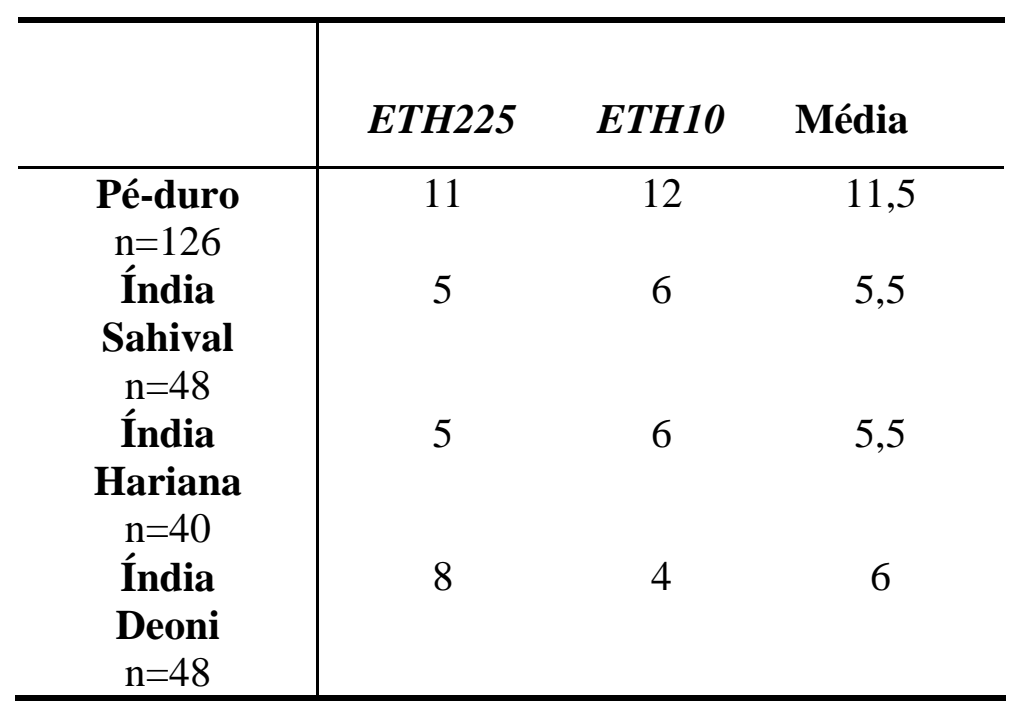

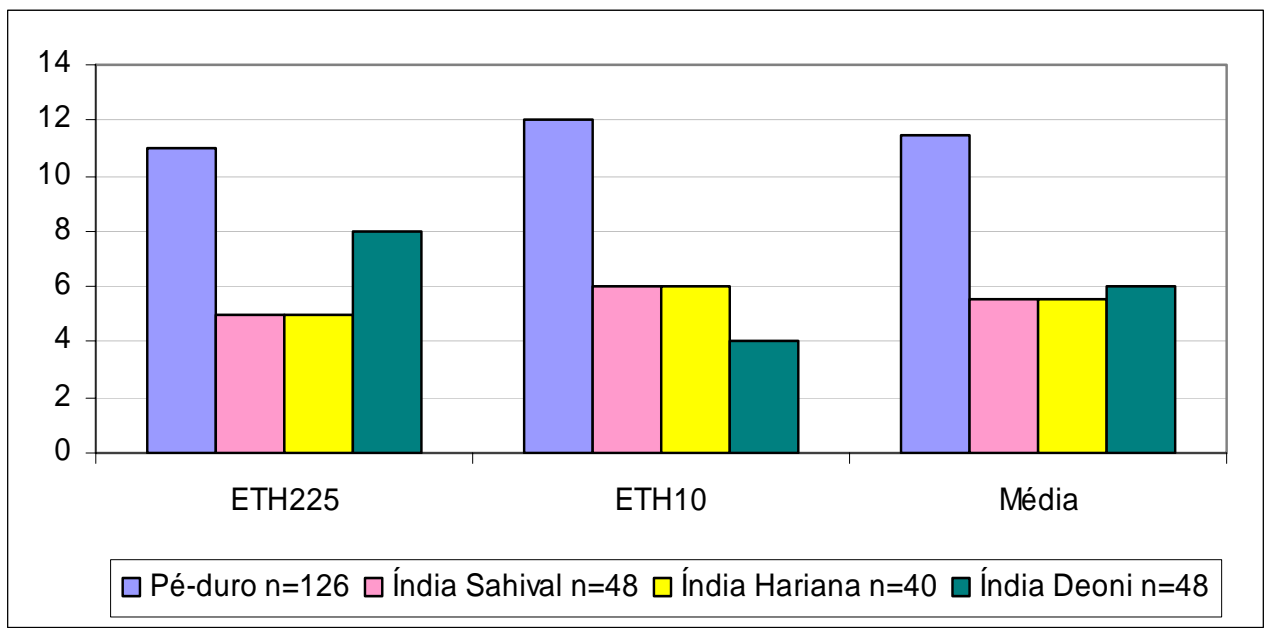

Gráfico 24. Gráfico comparativo do número de alelos (Na) amostrados por loco entre Pé-duro (Bos taurus) e raças nativas da Índia (Bos indicus). 
Tabela 16. Valores comparativos do conteúdo de informação de polimorfismo (Pic) por loco entre Pé-duro (Bos taurus) e raças nativas da Índia (Bos indicus).

\begin{tabular}{c|ccc}
\hline & ETH225 & ETH10 & Média \\
\hline $\begin{array}{c}\text { Pé-duro } \\
\text { n=126 } \\
\text { Índia } \\
\text { Sahival } \\
\text { n=48 } \\
\text { Índia } \\
\text { Hariana } \\
\text { n=40 } \\
\text { Índia } \\
\text { Deoni } \\
\text { n=48 }\end{array}$ & 0,745 & 0,864 & 0,802 \\
\hline
\end{tabular}

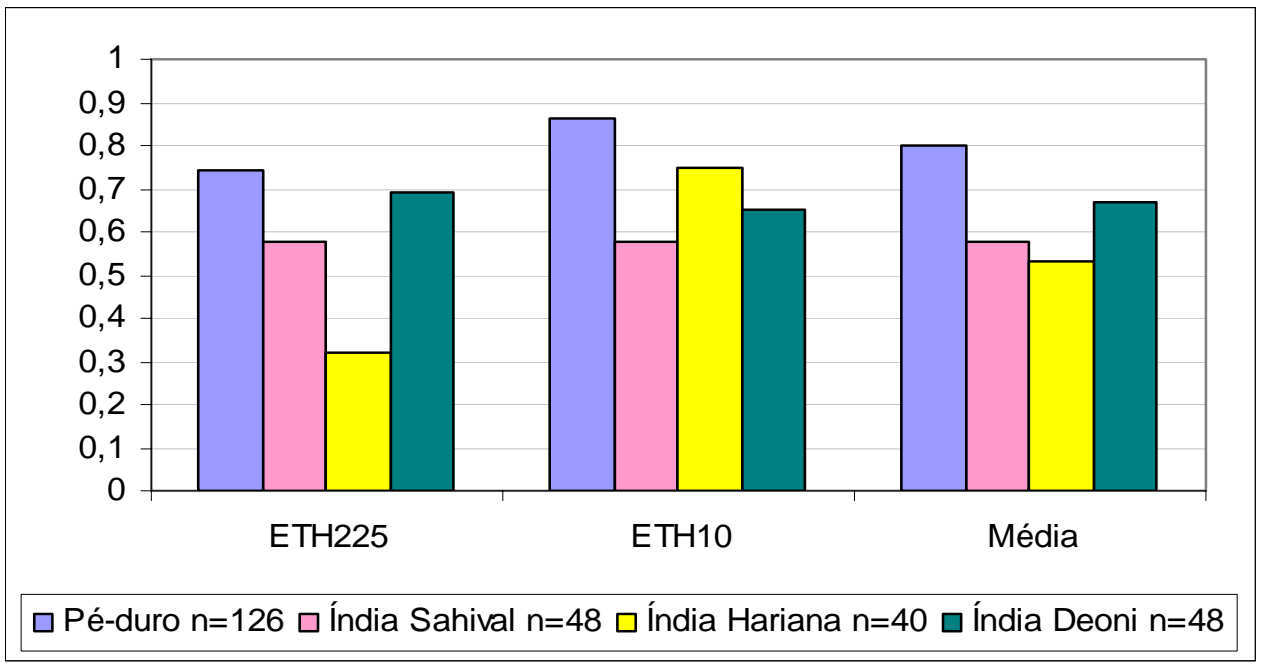

Gráfico 25. Valores comparativos do conteúdo de informação de polimorfismo (Pic) por loco entre Pé-duro (Bos taurus) e raças nativas da Índia (Bos indicus). 
Tabela 17. Valores comparativos do número de alelos amostrados por loco entre Péduro (Bos taurus) e raças comerciais Polish Red, Hereford, Holstein-Friesian (Bos taurus) e Gir e Nelore (Bos indicus).

\begin{tabular}{|c|c|c|c|c|c|c|c|c|c|c|}
\hline & SPS115 & BM1824 & BM2113 & TGLA122 & ETH225 & ETH10 & INRA23 & UWCA46 & BMS348 & Média \\
\hline $\begin{array}{l}\text { Pé-duro } \\
\mathrm{n}=126\end{array}$ & 6 & 6 & 9 & 20 & 11 & 12 & 15 & 14 & 3 & 11,3 \\
\hline $\begin{array}{l}\text { Polish } \\
\text { Red } \\
n=51\end{array}$ & 6 & 4 & 8 & 5 & 6 & 7 & 9 & & & 9 \\
\hline $\begin{array}{l}\text { Hereford } \\
n=56\end{array}$ & 6 & 5 & 7 & 5 & 6 & 6 & 5 & & & 5 \\
\hline $\begin{array}{l}\text { Holstein- } \\
\text { Friesian } \\
n=58\end{array}$ & 7 & 5 & 6 & 10 & 6 & 6 & 6 & & & 6 \\
\hline $\begin{array}{l}\text { Gir } \\
\mathrm{n}=40 \\
\text { famílias }\end{array}$ & 5 & 4 & & 12 & & 3 & & & & 6 \\
\hline $\begin{array}{l}\text { Nelore } \\
n=200\end{array}$ & & 10 & 6 & 16 & 10 & 8 & 9 & & & 9,8 \\
\hline $\begin{array}{c}\text { Nelore } \\
n=137\end{array}$ & & 7 & 8 & & & & & 11 & 3 & 7,25 \\
\hline
\end{tabular}

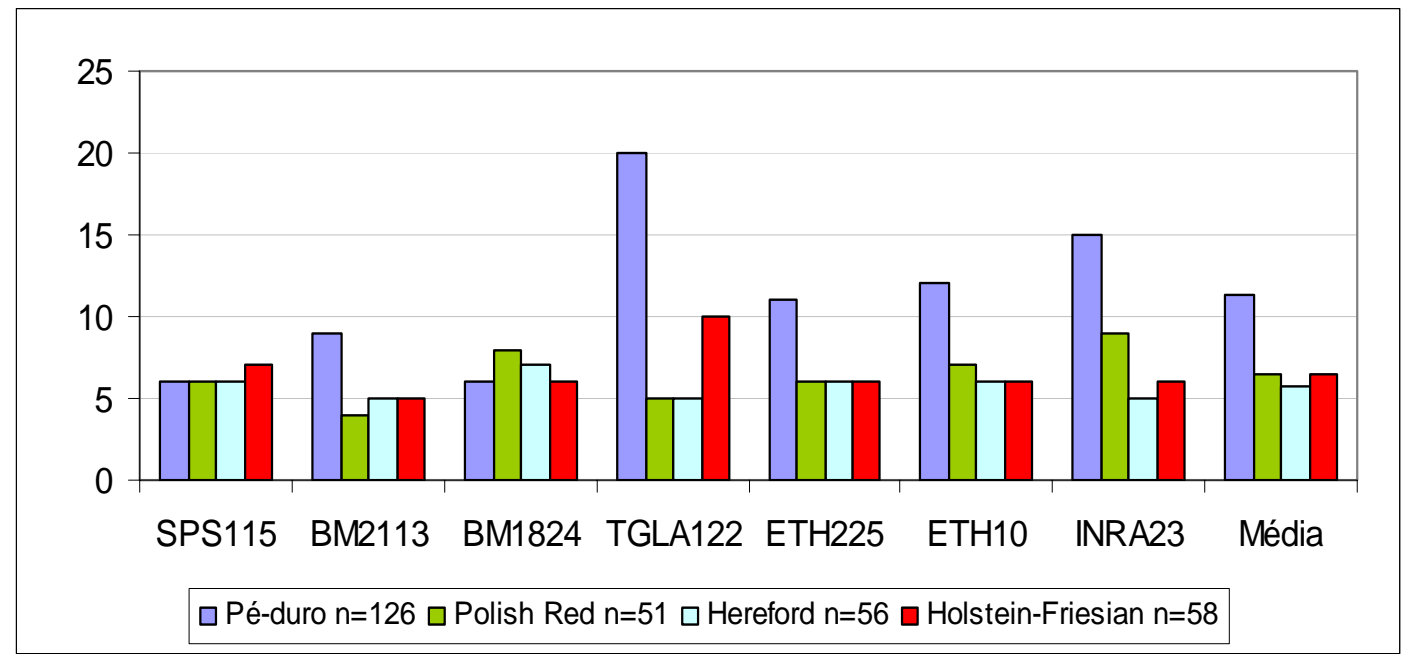

Gráfico 26. Gráfico comparativo do número de alelos amostrados por loco entre Pé-duro (Bos taurus) e populações de raças comerciais Polish Red, Hereford e Holstein-Friesian (Bos taurus). 


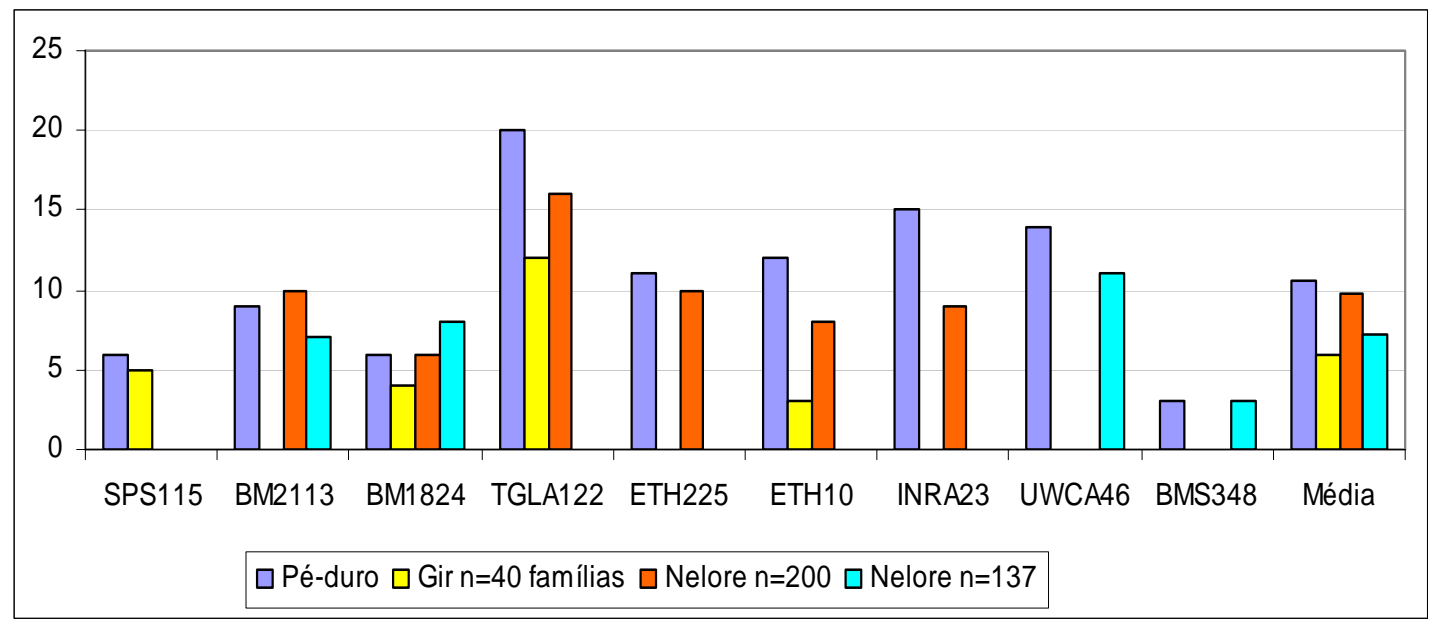

Gráfico 27. Gráfico comparativo do número de alelos amostrados por loco entre Pé-duro (Bos taurus) e raças comerciais Gir e Nelore (Bos indicus).

Tabela 18. Valores comparativos do conteúdo de informação de polimorfismo (Pic) por loco entre Pé-duro (Bos taurus) e raças comerciais Polish Red, Hereford, Holstein-Friesian (Bos taurus) e Gir e Nelore (Bos indicus).

\begin{tabular}{l|l|l|l|l|l|l|l|l|l|l}
\hline & SPS115 & BM1824 & BM2113 & TGLA122 & ETH225 & ETH10 & INRA23 & UWCA46 & BMS348 & Média \\
\hline $\begin{array}{l}\text { Pé-duro } \\
\text { n=126 }\end{array}$ & 0,657 & 0,722 & 0,739 & 0,902 & 0,745 & 0,864 & 0,884 & 0,901 & 0,397 & 0,75 \\
\hline $\begin{array}{l}\text { Polish } \\
\text { Red } \\
\text { n=51 }\end{array}$ & 0,729 & 0,627 & 0,808 & 0,559 & 0,753 & 0,700 & 0,825 & & & 0,71 \\
\hline $\begin{array}{l}\text { Hereford } \\
\text { n=56 }\end{array}$ & 0,751 & 0,569 & 0,801 & 0,744 & 0,713 & 0,684 & 0,596 & & & 0,69 \\
\hline $\begin{array}{l}\text { Holstein- } \\
\text { Friesian } \\
\text { n=58 }\end{array}$ & 0,633 & 0,711 & 0,743 & 0,639 & 0,621 & 0,530 & 0,740 & & & 0,65 \\
\hline $\begin{array}{l}\text { Gir } \\
\text { n=40 } \\
\text { famílias }\end{array}$ & 0,311 & 0,259 & & 0,589 & & 0,340 & & & & 0,37 \\
\hline $\begin{array}{l}\text { Nelore } \\
\mathrm{n}=200\end{array}$ & 0,612 & 0,691 & 0,827 & 0,683 & 0,565 & 0,835 & & & 0,70 \\
\hline $\begin{array}{l}\text { Nelore } \\
\mathrm{n}=137\end{array}$ & & 0,304 & 0,260 & & & & & 0,742 & 0,085 & 0,34 \\
\hline
\end{tabular}




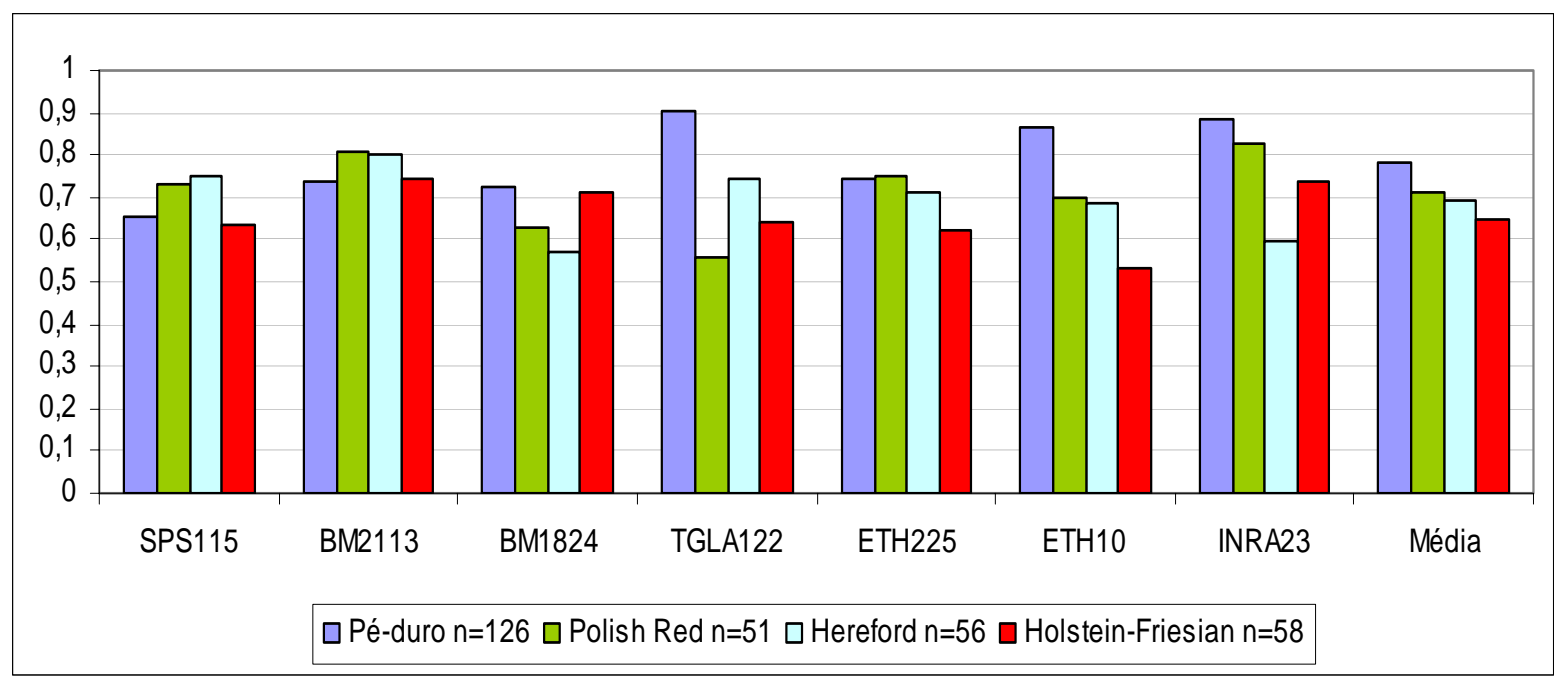

Gráfico 28. Gráfico comparativo do conteúdo de informação de polimorfismo (Pic) por loco entre Pé-duro (Bos taurus) e raças comerciais Polish Red, Hereford e Holstein-Friesian (Bos taurus).

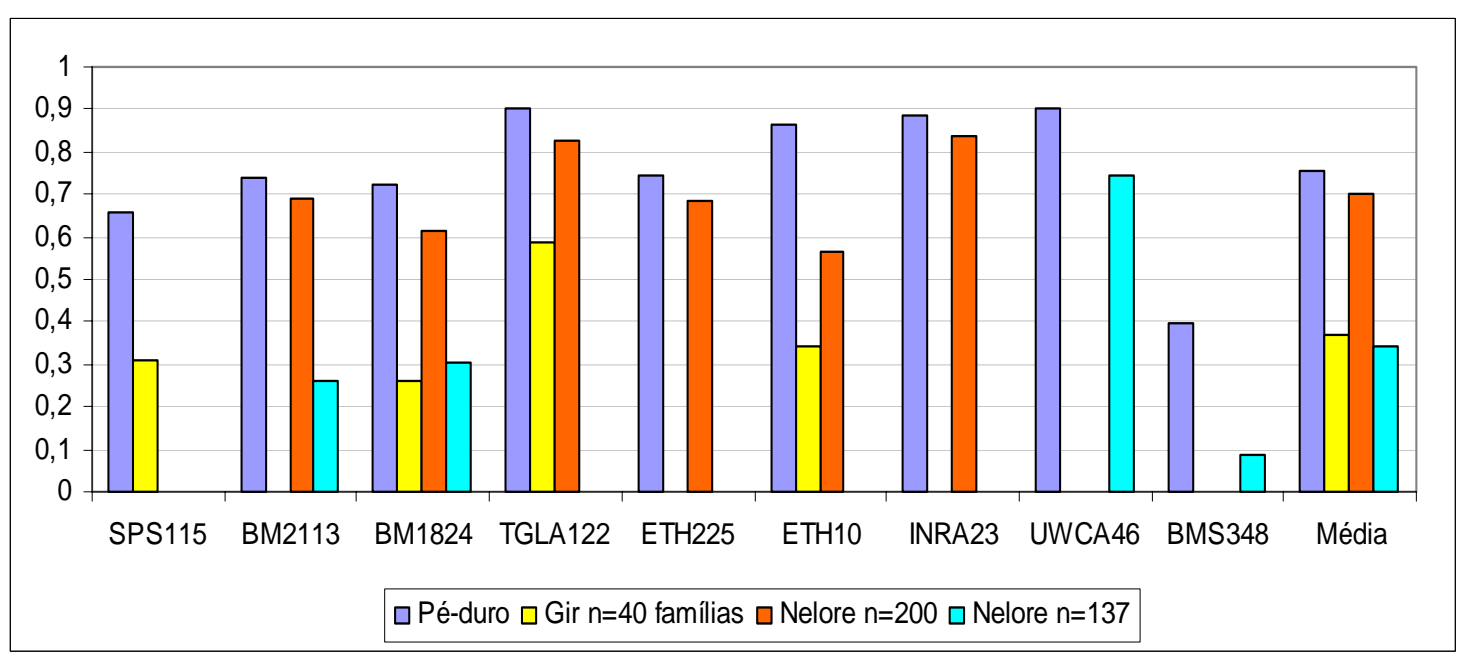

Gráfico 29. Gráfico comparativo do conteúdo de informação de polimorfismo (Pic) por loco entre Pé-duro (Bos taurus) e raças comerciais Gir e Nelore (Bos indicus). 


\section{DISCUSSÃO}




\subsection{Diversidade genética dentro da população Pé-duro.}

A população estudada no presente trabalho constitui-se de uma amostra dessa raça crioula, mantida no Centro de Pesquisa Agropecuária do Meio-Norte (Embrapa Meio-Norte) em São João do Piauí.

Considerando-se que a estimativa das freqüências dos alelos em uma amostra populacional é determinada pelo seu tamanho, taxa mutacional, fluxo gênico, efeito do fundador e deriva genética, Hedrick (2005) considera que o tamanho amostral adequado para o estudo de uma população estruturada deveria ser de no mínimo, 100 indivíduos. Nossa amostra, com n = 126, está, portanto, apropriada.

Todos os locos analisados na população Pé-duro foram polimórficos, portanto, informativos (Hedrick, 2005), como pode ser verificado nas Tabelas 4 e 5.

Os parâmetros utilizados para estudar a variação genética utilizando os dez locos microssatélites em Pé-duro - heterozigose e diversidade genética, conteúdo de informação de polimorfismo (Pic) número de alelos, riqueza alélica e coeficiente de endocruzamento (Fis) - indicaram existência de variabilidade na população desse gado do Piaú́ (Tabelas 4, 5 e 6). Presume-se que a heterozigose esperada, importante medida da variação genética (Nei, 1987, apud Hedrick, 2005) seja mais alta quando não existem divergência nos valores das freqüências dos alelos de um loco ou se existem muitos alelos em um loco, com freqüências semelhantes (Hartl e Clarck, 2007). Essa situação foi observada em nossas análises (Tabela 5) no que se refere aos locos TGLA122, ETH225, ETH10, INRA23 e UWCA46.

Apesar de todos os locos terem se mostrado polimórficos, observamos uma grande variação nos valores das freqüências alélicas especialmente no loco BMS4049, onde um único alelo (alelo 3) apresentou freqüência superior a 70\% (Tabela 5). 
Verificamos valores menores de heterozigose observada em relação à esperada segundo Hardy-Weinberg em todos os locos analisados (Tabela 6, Gráfico 2). A perda de variação genética mostrada pela redução da heterozigose na população Pé-duro deve ser devida ao isolamento da mesma o que tornou-a uma população estruturada extremamente adaptada a sua região local, o sertão nordestino. Essa subdivisão pode resultar em alto nível de endogamia (Hartl e Clarck, 2007), pelo fato dos indivíduos se reproduzirem dentro de seu próprio subgrupo. Validando este resultado, observamos também desvios do equilíbrio de Hardy-Weinberg e um valor significativo do coeficiente de endogamia Fis em todos os locos analisados (Tabelas 6 e 7, Gráfico 3). Barrera et al (2006), analisando 12 locos na raça crioula Romosinuana da Colômbia, obtiveram valores de heterozigose esperada e observada próximos aos observados no presente trabalho. O resultado de baixa heterozigose observada em relação à esperada foi também verificado por Mateus et al (2004) com a raça Mirandesa de Portugal, que deu origem a atual raça Pé-duro.

Desvios significativos do equilíbrio de Hardy-Weinberg $(\mathrm{p}<0,05)$ foram verificados em nove dos dez locos analisados em Pé-duro no teste exato, exceto no loco BMS348, e sugerem um aumento de homozigose na população estudada. O teste de déficit de heterozigotos também mostrou desvio significativo do equilíbrio de HardyWeinberg $(\mathrm{p}<0,05)$ em sete dos dez locos analisados, SPS115, BM2113, TGLA122, ETH225, ETH10, INRA23 e UWCA46 (Tabela 8), confirmando a diminuição de heterozigotos e o aumento de homozigose na população. Algumas causas dos desvios do equilíbrio de Hardy-Weinberg em locos microssatélites são relatadas em numerosos estudos e sugerem a ocorrência de uma série de eventos não excludentes como acasalamento não aleatório nas populações resultando em endogamia, resultado da presença de alelos nulos ou não-amplificados, efeito de amostragem, seleção contra 
heterozigotos, isolamento geográfico da população, efeito do fundador ou deriva genética. Esses resultados em Pé-duro são condizentes com os observados em populações geneticamente isoladas e estruturadas, tais como os relatados por BejaPereira et al (2003) e por Egito et al (2004).

O coeficiente de endogamia Fis é uma medida do grau de acasalamentos endogâmicos dentro de populações isoladas e estruturadas, como é o caso da população Pé-duro. Quando $F i s=0$, as freqüências genotípicas são idênticas àquelas do princípio de Hardy-Weinberg e quando $F i s=1$ (endogamia completa), todos os indivíduos são autozigóticos, ou seja, os alelos encontrados são idênticos por descendência (Hartl e Clarck, 2007). No presente estudo, verificamos valores significativos de Fis em nove dos dez locos analisados em Pé-duro, sendo a exceção o loco BM1824 (Tabelas 6 e 7, Gráfico 3). A conseqüência direta desses resultados é o excesso de genótipos homozigotos e deficiência de genótipos heterozigotos nessa população. Os resultados da análise do Fis são condizentes com os resultados do desvio do equilíbrio de HardyWeinberg e com os resultados de heterozigose observada menor em relação à esperada (Tabela 6) nos dez locos analisados. Barrera et al (2006) também observaram um valor significativo de Fis na raça crioula Romosinuana da Colômbia. Ambas são raças isoladas geograficamente e estruturadas, que sofreram diminuição de sua população ao longo dos anos, e por isso estão inscritas em programas de conservação (Barrera et al, 2006). Egito et al (2007) também encontraram um valor considerável do coeficiente de endogamia na população Curraleira analisada.

Se programas de conservação não acontecerem efetivamente, talvez a variação genética ainda encontrada e muitos dos alelos observados nos locos analisados neste momento na população Pé-duro, poderão vir a ser perdidos nas próximas gerações. 


\subsection{Diversidade genética comparativa entre Pé-duro e outras populações.}

A análise comparativa de Pé-duro com outros gados nativos taurinos (Casanare, Asiático, Uruguaio, Nativo Jersey e Nativo Europeu) mostrou alta diversidade genética evidenciada pelos valores de diversidade gênica, número de alelos e riqueza alélica (Tabelas 9, 10 e 13 e Gráficos 4 ao 14 e 23).

De um modo geral os valores de diversidade gênica e riqueza alélica mantiveram-se elevados em Pé-duro em relação às demais raças. Semelhanças dos valores de diversidade gênica e riqueza alélica em relação aos da raça Pé-duro ocorreram na raça Casanare da Colômbia (Sastre, 2003), que é uma raça crioula, isolada e adaptada a sua região local, como a raça Pé-duro. O mesmo pôde ser observado em relação à população nativa da Europa (Cañón et al, 2001) que também é constituída por gado adaptado à região que engloba Espanha, Portugal e França. Segundo Lirón et al (2006), pequenos tamanhos amostrais de raças de gado crioulo podem estar relacionados com a perda de diversidade; entretanto, os dados de diversidade gênica, número de alelos e riqueza alélica dos locos microssatélites ainda mostram um considerável grau de variabilidade genética na população Pé-duro.

Verificamos que na análise comparativa do número de alelos por loco, o valor obtido na população Pé-duro é semelhante ao obtido no estudo de Mateus et al (2004), com raças nativas de Portugal (Tabela 10 e Gráficos 10 a 14). Uma das raças de Portugal estudadas por esses autores é a Mirandesa, que foi trazida pelos colonizadores portugueses e que deu origem à atual raça Pé-duro. As raças nativas portuguesas são raças caracterizadas por apresentarem diversidade genética e são muito importantes como animais de trabalho e fonte de alimento das populações rurais portuguesas; por isso estão inseridas em programas de conservação local (Mateus et al, 2004). 
Quando a comparação do número alelos de Pé-duro é feita com o gado crioulo do Uruguai (Armstrong et al, 2006) - que é uma raça nativa isolada e estruturada e se desenvolveu no isolamento reprodutivo a partir do século 19 devido à introdução de raças comerciais - e a raça Jersey do Reino Unido (Chikhi et al, 2004) - que é uma raça que já sofreu pressões seletivas e, conseqüentemente, perda de diversidade observamos que a população Pé-duro apresenta maior número de alelos em relação a ambas (Gráficos 13 e 14). Esse resultado pode ser considerado como um indicador de diversidade genética em Pé-duro enquanto que os menores valores do número de alelos observados em Jersey e crioulo do Uruguai sugerem que alguns alelos já foram perdidos e outros estão fixados por deriva, nessas populações. Portanto, conclui-se que a diversidade genética encontrada atualmente em Pé-duro poderá se perder nas futuras gerações se programas de conservação e reprodução assistida não forem efetivamente aplicados.

Na análise comparativa dos valores de heterozigose observada de Pé-duro em relação às raças Casanare da Colômbia (Sastre, 2003), crioula do Uruguai (Armstrong et al, 2006) e Jersey do Reino Unido (Chikhi et al, 2004), observamos valores menores na maioria dos locos na população brasileira (Tabela 11). Uma importante conseqüência para a estrutura de uma população, nas populações isoladas e finitas como a Pé-duro, é a redução da proporção de genótipos heterozigotos em relação ao esperado. A heterozigose é uma medida de diversidade genética que depende da freqüência dos diferentes alelos em um loco (Hedrick, 2005). Quando observamos a Tabela 5 podemos verificar que em Pé-duro, alguns locos apresentam um alelo com freqüência muito alta e os outros têm freqüências próximas de zero. Quando essa situação ocorre, a heterozigose diminui porque a maioria dos indivíduos são homozigotos para o alelo mais freqüente (Hartl e Clarck, 2007 ). Contudo, Pé-duro apresentou maior diversidade 
gênica e maior número de alelos amostrados nos locos BM2113, TGLA122, ETH225 e ETH10 (Tabelas 9 e 10, Gráficos 4 a 9 e 10 a 14). Estas observações sugerem que os menores valores de heterozigose observada nos locos analisados na população Pé-duro, poderiam ser explicados pelo isolamento geográfico, ocorrência de acasalamentos endogâmicos e deriva genética.

A análise comparativa do coeficiente de endogamia Fis quando consideramos também raças nativas taurinas da Catalunha e da África (Tabela 12, Gráficos 19 a 22), mostrou valores bem divergentes, evidenciando novamente em Pé-duro valores altamente significativos em todos os locos analisados, exceto no loco BM1824. Estes resultados mostram que determinadas práticas de criação e de melhoramento genético em praticamente todas as populações de bovinos, incluindo a Pé-duro, as submeteram ou ainda submetem a pressões seletivas. Estas pressões podem conferir altas taxas de endogamia provocadas pelo isolamento e pelo acasalamento não aleatório que, como conseqüência, provoca o aumento de genótipos homozigotos e deficiência de genótipos heterozigotos (Hartl e Clarck, 2007). A homozigose aumentada pode contribuir para a suscetibilidade a infecções e outras doenças ou para a extinção de populações (Keller e Waller, 2002). Ou, ainda, para a perda de adaptabilidade provocada pela perda de alelos que poderiam estar ligados a genes que seriam de fundamental importância no futuro. A população Pé-duro analisada é caracterizada por ser uma população pequena (n=126) e isolada, localizada no núcleo de conservação do Centro de Pesquisa Agropecuária do Meio-Norte (Embrapa Meio-Norte); em 2004 o número total de indivíduos era de aproximadamente 350 animais (Carvalho, comunicação pessoal, 2007), o que justificaria o significante valor de Fis encontrado.

As análises comparativas do número de alelos e de conteúdo de informação de polimorfismo, com três raças zebuínas nativas da Índia (Radko et al, 2005), com raças 
comerciais taurinas Hereford, Polish Red e Holstein-Friesian (Mukesh et al, 2004) e raças comerciais zebuínas Nelore (Cervini et al, 2006; Lara et al, 2005) e Gir (Curi et al, 2002), de uma maneira geral indicaram uma maior diversidade genética em Pé-duro (Tabelas 15, 16, 17 e 18, Gráficos 24 a 29).

Especificamente na análise comparativa do número de alelos considerando as três populações nativas Indianas, elas apresentaram menor número de alelos nos dois locos analisados e menor média em relação a Pé-duro (Tabela 15, Gráfico 24). As raças nativas Indianas Sahiwal, Hariana e Deoni apresentam adaptabilidade e resistência em ambientes tropicais hostis, com condições climáticas extremas e pobreza de nutrientes, além de possuírem importância histórica e prática para as comunidades de suas respectivas regiões na Índia. Essas três raças apresentaram um significativo valor médio de Fis e déficit de heterozigotos nos vinte locos analisados (Radko et al, 2005), assim como verificamos no presente estudo com Pé-duro.

Quando a comparação foi feita entre Pé-duro e raças comerciais taurinas Hereford, Polish Red e Holstein-Friesian (Mukesh et al, 2004) e zebuínas Gir (Curi e Lopes 2002), observamos um maior número de alelos em todos os locos e no valor médio na população crioula estudada. De acordo com Lirón et al (2006) populações de gado crioulo mostram uma relativa variação genética de diversidade alélica estimada, enquanto que raças zebuínas exibem um valor intermediário. Em relação à raça zebuína Nelore (Cervini et al, 2006) foram observadas mais semelhanças nos valores em relação a Pé-duro, indicando alguma perda de diversidade ou fixação de alguns alelos na população crioula estudada (Tabela 17). Esta perda de diversidade pode ser devida ao cruzamento indiscriminado de raças crioulas, incluindo a raça Pé-duro - ocorrido no Brasil principalmente no início do século XX - com raças zebuínas de maior tamanho; 
com isso, muitos animais mestiços foram formados principalmente pela castração e substituição dos reprodutores da raça Pé-duro por touros zebus (Carvalho, 1985).

A análise do Pic apresentou valores maiores em Pé-duro (Bos taurus) em todos os locos analisados em relação às demais raças comerciais analisadas Hereford, Holstein-Friesian (Bos taurus) e Gir e Nelore (Bos indicus), indicando assim alta diversidade, uma vez que valores de Pic maiores que 50\% são considerados informativos (Tabela 18 e Gráficos 28 e 29).

Quando a comparação foi feita com o trabalho de Lara et al (2005) com a raça Nelore (locos BM2113, BM1824 e BMS348) e a raça Gir de Curi e Lopes (2002) (locos SPS115, BM1824, TGLA122 e ETH10) estes valores são muito discrepantes.

Nos trabalhos de Cervini et al (2006) com a raça zebuína Nelore e Mukesh et al (2004) com as raças comerciais taurinas Hereford, Polish Red e Holstein-Friesian, foram verificadas pequenas diferenças dos valores de Pic nos locos quando comparados aos obtidos em Pé-duro. De acordo com Cervini et al (2006), esta diferença em variabilidade para alguns locos é devida ao fato de serem muito mais informativos em Bos taurus, e menos informativos em B. indicus. Esses resultados são consistentes com Lirón et al (2006) que analisaram um grupo de dez raças crioulas taurinas e raças zebuínas da Argentina e Bolívia e com Egito et al (2007) que também analisaram dez raças nativas crioulas taurinas e raças zebuínas. 
VI. CONCLUSÃO 
Todas as análises feitas com os dez locos em bovinos Pé-duro mostraram dados consistentes e confiáveis sob o ponto de vista genético. Tanto o valor do coeficiente de endogamia estatisticamente significativo, como os baixos resultados obtidos para heterozigose observada, baixa freqüência dos alelos e desvios do equilíbrio de HardyWeinberg nos levam a inferir sobre alto grau de homozigose na população de Pé-duro analisada. Foi possível verificar que ainda existe diversidade genética nesta raça nativa brasileira, que foi evidenciada pelos valores obtidos nos índices de diversidade (diversidade gênica, heterozigose esperada e riqueza alélica). Essa diversidade poderá ser perdida nas próximas gerações se programas de conservação não forem desenvolvidos para modificar a realidade evidenciada pelo presente estudo. Seria ideal em estudos futuros fazer uma análise com várias populações da raça Pé-duro da região Nordeste e aumentar o número de marcadores utilizados, tentando um programa abrangente de conservação. Uma das metas seria a criação de vários núcleos de conservação que possibilitariam a ocorrência de acasalamentos assistidos, possibilitando o fluxo gênico entre diferentes populações; uma outra seria a criação de bancos de germoplasma animal, ação de fundamental importância para estabelecer condições eficazes para a conservação desta raça histórica do Brasil. 


\section{REFERÊNCIAS BIBLIOGRÁFICAS}


ALMEIDA, S. E. M., MACHADO, M. S. M., STEIGLEDER C. S., GAMA, C. L., HUTZ, M. H., HENKES L. E., MORAES, J. C. F. e WEIMER,T. A. (2000) Genetic diversity in a Brazilian bovine herd based on four microsatellite loci. Genet. Mol. Biol. 23 (2): $347-350$.

ARMStrong, E., POStiglioni, A., MARTíneZ, A., RinCÓN, G. e VEGA-PLA, J. L. (2006) Microsatellite analysis of a sample of Uruguayan Creole bulls (Bos taurus). Gen. Mol. Biol. 29 (2): 267 - 272.

ATHANASSOF, N. (1957) Manual do criador de bovinos. Melhoramentos, 6 . ed. São Paulo.

BARENDSE, W., VAIMAN, D., KEMP, S. J., SUGIMOTO, Y., ARMitAgE, S. M., WILliams J. L., SUN, H. S., EgGEN, A., AGABA, M., ALEYASIN, S. A., BAND, M., BISHOP, M. D., BUITKAMP, J., BYRNE, K., COLLINS, F., COOPER, L., COPPETTIERS, W., DENYS, B., DRINKWATER, R. D., EASTERDAY, K., ELDUQUE, C., ENNIS, S., ERHARDT, G., LI, L., MARTIN BURRIEL, I., MCGRAW, R. A., MILLER, J. R., MOODY D. E., MOORE, S. S., NAKANE, S., NIJMAN, I.J., OLSAKER, I., POMP, D., RNDO, A., RON, M., SHAlOM, A., TEALE, A. J., THIEVEN, U., IRQUHART, B. G. D., VAGE, D.I., VAN DE WEGHE, A., VARVIO, S., VELMALA, R., VILKKI, J., WEIKARD, R., WOODSIDE, C., WOMACK, J. E., ZANOTTI, M., ZARAGOZA, P. (1997) A medium density genetic linkage map of the bovine genome. Mamm. Genome 8: 21 - 28. 
BARRERA, P. G., MARINEZ, R., PEREZ E. J., POLANCO, N. e ARIZA, F. (2006) Evaluación de la variabilidad genética em ganado Criollo Colombiano mediante 12 marcadores microssatélites. Anim. Gen. Resources Inform. 38: 35 - 45.

BEJA-PEREIRA, A., ALEXANDRINO, P., BESSA, I., CARRETERO, Y., DUNNER, S., FERRAND, N., JORDANA, J., LALOE, D., MOAZAMI-GOUDARZI, K., SANCHEZ, A. e CAÑÓN, J. (2003) Genetic characterization of southwestern European bovine breeds: A historical and biogeographical reassessment with a set of 16 microsatellites. J. Hered. 94 (3): 243 - 250.

BISHOP, M.D., KAPPES, S.M., KEELE, J.W., STONE, R.T., SUNDEN, S.L.F., HAWKINS, G.A., TOLDO, S.S., FRIES, R., GROSZ, M.D., YOO, J. e BEATTIE, C.W. (1994) A genetic linkage map for cattle. Genetics 136: 619-639.

BRITTO, C. M. C. (1998) Citogenética do Gado Pé-duro. EDUFPI, Teresina.

CAÑÓN, J., ALEXANDRINO, P., BESSA, I., CARLEOS, C., CARRETERO, Y., DUNNER, S., FERRAN, N., GARCIA, D., JORDANA, J., LALOE, D., PEREIRA, A., SANCHEZ A. e MOAZIMI-GOUDARZI, K. (2001) Genetic diversity measures of local European beef cattle breeds for conservation purposes. Genet. Sel. Evol. 33: 311 332.

CARVALHO, J. H. (1985) Pé-duro, patrimônio preservado no Piauí. Dirigente Rural 8:24-26. 
CARVALHO, J. H. (2000) Conservação de recursos genéticos de animais domésticos do Nordeste. In: Congresso Nordestino de Produção Animal, 2, Teresina. Anais... Teresina: Sociedade Nordestina de Produção Animal, 20-23 nov. Embrapa Meio-Norte, vol.1: 65-70.

CARVAlHO, J. H. (2002) Potencial econômico do bovino Pé-duro. Teresina: Embrapa Meio-Norte Documentos vol.65. Teresina.

CARVALHO, J. H., MONTEIRO, F.C. e GIRÃO, R.N. (2001) Conservação do bovino Pé-duro ou Curraleiro: situação atual. Embrapa Meio-Norte Documentos vol. 58. Teresina.

CASELLAS, J., JIMÉNEZ, N., FINA, M., TARRÉS, J., SÁNCHEZ, A. e PIEDRAFITA, J. (2004) Genetic diversity measures of the bovine Alberes breed using microsatellites: viability among herds and types of coat colour. J. Anim. Breed. Genet. 121: $101-110$.

CERVINI, M., HENRIQUE-SILVA, F., MORTARI, N. E. e Jr. MATHEUCCI E. (2006) Genetic variability of 10 microsatellite markers in the characterization of Brazilian Nellore catlle (Bos indicus). Gen. Mol. Biol. 29 (3): 486 490.

CHIKHI, L., GOOSSENS, A., TREANOR, A. e BRUFORD, M. W. (2004) Population genetic structure of and inbreeding in an insular cattle breed, the Jersey, and its implications for genetic resource management. J. Hered. 92: 396 - 401. 
CIAMPOLINI, R., MOAZAMI-GOUDARZI, K., VAIMAN, D., DILLMANN C., MAZZANTI, E., FOULLEY, J-E., LEVEZIEL, H. e CIANI, D. (1995) Individual multilocus genotypes using microsatellite polymorphisms to permit the analysis of the genetic variability within and between Italian beef cattle breeds. J. Anim. Sci. 73: 3259 $-3268$.

CURI, R. A. e LOPES, C. R. (2002) Evaluation of nine microsatellite loci and misidentification paternity frequency in a population of Gyr breed bovines. Braz. J.Vet. Res. Anim. Sci. 39 (3): 129 - 135.

DOMINGUES, (1961) As raças bovinas nativas: o gado nos trópicos. Instituto de Zootecnia. (Série Monografia). Rio de Janeiro.

EGITO, A. A., PAIVA, S. R., MAMANÍ, E. M., ALBUQUERQUE, M. S. M., MCNAMUS, C., CASTRO, S., MARIANTE, A. S. e GRATTAPAGLIA, D. (2004) Variabilidade genética de raças bovinas baseada em marcadores STR. In: V Simpósio da Sociedade Brasileira de Melhoramento Animal, Pirassununga-SP.

EGITO, A. A., PAIVA, S. R., ALBUQUERQUE, M. S. M., MARIANTE, A. S. ALMEIDA, L. D., CASTRO S. R. e GRATTAPAGLIA, D. (2007) Microsatellite based genetic diversity and relationships among ten Creole and commercial cattle breeds raised in Brazil. BioMed Central Genetics 8: 83. 
EL MOUSADIK A. e PETIT R.J. (1996) High level of genetic differentiation for allelic richness among populations of the argan tree [Argania spinosa (L.) Skeels] endemic to Morocco. Theor. Appl. Genet. 92: 832-839

FAO (1984) Manual for training courses on the animal genetic resources conservation and management. Budapeste.

FAO (1995) Global Project for the Maintenance of Domestic Animal Genetic Diversity. Disponível em: <http://www.fao.org/dad-is/>. Acesso em 2005.

FAO (2004) Global Project for the Maintenance of Domestic Animal Genetic Diversity. Disponível em: <http://www.fao.org/dad-is/> . Acesso em 2005.

FELIUS, M. (1985) Genus Bos: Cattle Breeds of the World. Rahway NJ: Merck Sharp \& Dohme-AGVET, Division of Merck and Co. 235p.

FRIES, R., EGGEN, A. e WOMACK, J. E. (1993) The bovine map. Mamm. Genome 4: 405 - 428.

GOUDET, J. (2001) FSTAT, a program to estimate and test gene diversities and fixation indices. Version 2.9.3. http://www.unil.ch/izea/softwares/fstat.html.

HARTL, D. L. e CLARK, A. G. (2007) Principles of population genetics. 4a. ed. Sinauer, MA. 
HEDRICK, P.W. (2005). Genetics of Populations .3a.ed. Jones and Bartlett, Boston, MA.

HIGUCHI, R. (1989). Simple and rapid preparation of samples for PCR. In: ERLICH, H. A., (Ed.) PCR technology - principles and applications for DNA amplification. Stockton Press, NY.

HURLBERT, S. H. (1971) The nonconcept of species diversity: a critique and alternative parameters. Ecology 52: 577-586

IBEAGHA-AWEMU E. M. e ERHARDT, G. (2005) Genetic structure and differentiation of 12 African Bos indicus and Bos taurus cattle breeds, inferred from protein and microsatellite polymorphisms. J. Anim. Breed. Genet. 122: 12 - 20.

KANTANEN, J., OLSAKER I., HOLM, L.-E., LIEN, S., VILKKI, J., BRUSGAARD, K., EYTHORSDOTTIR, E., DANELL, B. e ADALSTEINSSON, S. (2000) Genetic diversity and population structure of 20 North European catlle breeds. $J$. Hered. 91: (6): $446-457$.

KAPPES, S. M., FEELE, J. W., STONE, R. T., MACGRAW, R. A., SONSTEGARD, T. S., SMITH, T. P. L., LOPEZ-CORRALES N. L. e BEATIIE, C. W. (1997) A second generation linkage map of the bovine genome. Genome Res. 7: 235 249. 
KELLER, L. K. e WALLER, D. M. (2002) Inbreeding effects in wild populations. Trends Ecol. Evol. 17(5): 230 - 241.

KIM, K. S., YEO, J. S. e CHOI, C. B. (2002) Genetic diversity of north-east Asian catlle based on microsatellite data. Anim. Genet. 33: 201 - 204.

LARA, M. A. C. (1998) Variabilidade genética em bovinos e bubalinos através de polimorfismos protéicos: análise populacional e suas implicações no melhoramento. Tese de Doutorado. Faculdade de Medicina de Ribeirão Preto da Universidade de São Paulo.

LARA, M. A. C., CONTEL, E. P. B. e SERENO J. R. B. (2005) Caracterización genética de poblaciones cebuínas através de marcadores moleculares. Arch. Zootec. 54: 295 - 303.

LEBERG, P. L. (2002) Estimating allelic richness: effects of a sample size and bottlenecks. Molec. Ecol. 11: 2445-2449.

LEWIS, P. O. e ZAYKIN, D. (1997) Genetic data analysis: software for the analysis of discrete genetic data. Version 1.0.

LIRÓN, J. P., PERAL-GARCÍA, P. e GIOVAMBATTISTA, G. (2006) Genetic characterization of Argentine and Bolivian Creole cattle breeds assessed through microsatellites. J. Hered. 97 (4): 331 - 339. 
LOFTUS, R. T., MACHUGH, D. E., BRADLEY, D. G., SHARP, P. M., e CUNNINGHAM, P. (1994) Evidence for two independent domestications of catlle. Proc. Natl. Acad. Sci. 91: $2757-2761$.

MACHUGH, D. E., SHIVER, M. D., LOFTUS, R. T., CUNNINGHAM, P. e BRADLEY, D. G. (1997) Microsatellite DNA variation and the evolution, domestication and phylogeography of taurine and zebu catlle ( Bos taurus and Bos indicus). Genetics 146 (3): 1071 - 1086.

MACHUGH, D. E., LOFTUS, R. T., CUNNINGHAM, P. e BRADLEY, D. G. (1998) Genetic structure of seven European catlle breeds assessed using 20 microsatellites markers. Anim. Genet. 29: 333 - 340.

MALAU-ADULI, A. E. O., NIIBAYASHI, T., KOJIMA, T., OSHIMA, K., MIZOGUCHI Y. e M. KOMATSU (2007) Detection and mapping of QTL on bovine chromosomes 2 and 5 segregating for live weight, average daily gain and body measurements in Japanese black cattle. Journal of Cell and Animal Biology 1 (3):34043.

MARIANTE, A. S. e CAVALCANTE, N. (2006) Animais do descobrimento: raças domésticas da história do Brasil. EMPRABA, 2a . ed. Brasília.

MARSHALL, T. C., SLATE, J., KRUUK, L. E. B. e PEMBERTON, J. M. (1998) Statistical confidence for likelihood-based paternity inference in natural populations. Molec. Ecol. 7: 639-655. 
MAteus, J. C., PENEDO, M. C. T., AlveS, V. C., RAMOS, M. e RANGEL-FIGUEIREDO, T. (2004) Genetic diversity and diferentiation in Portuguese cattle breeds using microsatellites. Anim. Genet. 35: 106 - 113.

MAUDET, C., LUIKART, G. e TABERLET, P. (2002) Genetic diversity and assignment tests among seven French catlle breeds based on microsatellites DNA analysis. J. Anim. Sci. 80: 942 - 949.

MIRETTI, M. M. (2002) Variabilidade no DNA mitocondrial e filogeografia de bovinos nativos americanos. Tese de Doutorado. Faculdade de Medicina de Ribeirão Preto da Universidade de São Paulo.

MIRETTI, M. M., DUNNER, S., NAVES, M., CONTEL, E. P. e FERRO, J. A. (2004) African derived mtDNA in Spanish cattle (Bos taurus) is identical to the predominant African - derived mtDNA haplotype in Caribbean and Brazilian Creole cattle. J. Hered. 95: $450-453$.

MUKESH, M., SODHI, M., BHATIA, S. e MISHRA, P. (2004) Genetic diversity of Indian native cattle breeds as analysed with 20 microsatellite loci. J. Anim. Breed. Genet. 121: $415-424$.

MUÑOZ, J. (2007) Biodiversity conservation including uncharismatic species. Biodivers. Conserv. 16: $2233-2235$. 
NEI M, (1987) Molecular Evolutionary Genetics. Columbia University Press, New York.

PEELMAN, L. J., MORTIAUX, F., ZEVERAN, A. V., DANSERCOER, A., MOMMERS, G., COOPMAN, F., BOUQUET, Y., BURNY, A., RENAVILLE, R. e PORTELLE, D. (1998) Evaluation of the genetic variability of 23 bovine microsatellite markers in four Belgian catlle breeds. Anim. Genet. 29: 161 - 167.

PETIT R. J., EL MOUSADIK, A. e PONS, O. (1998) Identifying populations for conservation on the basis of genetic markers. Conserv. Biol. 12: 844-855.

POUGH, F. H., HEISER, J. B. e MCFARLAND, W. N. (1993) $A$ vida dos vertebrados. Atheneu Editora, São Paulo.

PRIMO, A. (1986) Conservación de recursos genéticos animales en el Brasil. Ganado Bovino Criollo. Orientación Gráfica Ed., Buenos Aires.

RABASA, C. (1993) El bovino Criollo en los distintos países de América. In: Ganado Bovino Criollo, $3^{\text {rd }}$ ed. Orientación Gráfica, Buenos Aires.

RADKO, A., ZYGA, A., ZABEK, T., e SLOTA, E. (2005) Genetic variability among Polish Red, Hereford and Holstein-Friesian cattle raised in Poland based on analysis of microsatellite DNA sequences. J. Appl. Genet. 46 (1): 89 - 91. 
RAMALHO FILHO, A. e BEEK, K. J. (1995) Sistema de Avaliação da Aptidão Agrícola das Terras. EMBRAPA-CNPS, 3a. ed., Rio de Janeiro.

RAYMOND, M. e ROUSSET, F. GENEPOP (1995) (version 2.0): population genetics software for exact tests and ecumenicism. J. Hered. 86: 248 - 249.

RITZ, L. R., GOLWATZKI-MULLIS, M-L., MACHUGH, D. E. e GAILLARD, C. (2000) Philogenetic analysis of the tribe Bovini using microsatellites. Anim. Genet. 31: $178-185$.

SANGUINETTI, C. J., NETO, E. D. e SIMPSON, A. J. G. (1994) Rapid silver staining and recovery of PCR products separated on polyacrylamide gels. Biotechniques 17: 209-214.

SANTIAGO, A. A. (1975) Os cruzamentos na pecuária bovina. São Paulo. Instituto de Zootecnia, 254 - 255. XIX Cap.

SANTIAGO, A. A. (1985) O zebu nos cruzamentos. São Paulo. Departamento de Produção Animal, $3^{\text {a. }}$ parte, XIX Cap.

SASTRE, H. J. (2003) Descripición, situación atual y estrategias de conservación de la raza bovina colombiana criolla casanare. Tesis Doctoral, Departamento de Producción Animal, Facultad de Veterinaria, Universidad de Córdoba, Espanha. 
SERRANO, G. M., EGITO, A. A., MCMANUS, C. e MARIANTE, A. S. (2004) Genetic diversity and population structure of Brazilian native bovine breeds. Pesq. Agropec. Bras. 39 (6): $543-549$.

SOLÉ-CAVA, A. M. (2004) Biodiversidade Molecular e Genética da Conservação. In Biologia Molecular e Evolução. Sergio Russo Matioli, ed. Holos Ed., Ribeirão Preto.

SPRITZE, A., EGITO, A. A., MARIANTE, A. S. e MCMANUS, C. (2003) Genetic characterization of Criollo Lageano cattle by RAPD markers. Pesq. Agropec. Bras. 38 (10): $1157-1164$.

STEFFEN, P., EGGEN, A., DIETZ, A. B., WOMACK, J.E., STRANZINGER, G. e FRIES, R. (1993) Isolation and mapping of polymorphic microsatellites in cattle. Anim. Genet. 24: $121-124$.

STONE, R T., PULIDO, J. C., DUYK, G. M., KAPPES, S. M., KEELE, J. W. e BEATIE, C. W. (1995) A small-insert bovine genomics library highly enriched for microsatellite repeat sequences. Mamm. Genome 6: 714 - 724.

STONE, R.S., KAPPES, S.M. e BEATTIE, C.W. (1996) Five polymorphic trinucleotide (CCA) bovine microsatellites. Anim. Genet. 27 (3): 216.

SUN, H. S., BARENDSE, W. e KIRKPATRICK B. M. (1995) “UWCA46” a polymorphic bovine microsatellite marker. J. Anim. Sci. 73: 1530. 
VAIMAN, D., MERCIER, D., MOAZAMI-GOUDARZI, K., EGGEN, A., CIAMPOLINI, R., LÉPINGLE, A., VELMALA, R., KAUKINEN, J., VARVIO, S. L., MARIN, P., LEVÉZIEL, H. e GUÉRIN, G. (1994) A set of 99 cattle microsatellites: characterization, synteny mapping and polymorphism. Mamm. Genome 5: 288 - 297.

VASCONCELLOS, L. P. M. K., TAMBASCO-TALHARI, D., PEREIRA, A. P., COUTINHO, L. L. e REGITANO, L. C. A. (2003) Genetic characterization of Alberdeen Angus catlle using molecular markers. Genet. Mol. Biol. 26 (2): 133 - 137. 
ANEXO

MANUSCRITO PARA PUBLICAÇÃO 


\section{“Caracterização genética por microssatélites de uma amostra populacional do rebanho bovino da raça Pé-duro do Piauí.”}

Ana Paula Ferreira de Oliveira ${ }^{(1)}$, José Herculano de Carvalho ${ }^{(2)}$, Maria Aparecida Cassiano Lara ${ }^{(3)}$, Marcos Mateo Miretti ${ }^{(4)}$ e Eucleia Primo Betioli Contel ${ }^{(1)}$

\footnotetext{
${ }^{(1)}$ Depto. de Genética, FMRP, USP, Avenida Bandeirantes 3900, 14049-900, Ribeirão Preto, SP, Brasil, anapfo@usp.br, epbconte@rge.fmrp.usp.br

${ }^{(2)}$ Associação Brasileira de Criadores de Gado Pé-Duro (ABPD), Rua Gov. Artur de Vasconcelos, 150-N, sala 08, 64001-450 Teresina, PI, Brasil, sjpapc@yahoo.com.br

${ }^{(3)}$ Instituto de Zootecnia, Nova Odessa, 13460-000, SP, Brasil, malara@iz.sp.gov.br

${ }^{(4)}$ Welcome Trust Sanger Institute, Hinxton, Cambridge, CB10 ISA, United Kingdom, mm3@sanger.ac.uk
}

\section{Resumo}

A raça Pé-duro do Piauí é extremamente bem adaptada às condições ambientais desfavoráveis da zona semi-árida do Nordeste Brasileiro e está em perigo de extinção. O objetivo deste trabalho foi caracterizar geneticamente, por microssatélites, uma amostra da raça Pé-duro, Bos taurus (n=126), originária da Fazenda Experimental Octavio Domingues, da Embrapa Meio-Norte, no estado do Piauí, Brasil. A variabilidade genética foi estimada através de freqüências gênicas, diversidade gênica, heterozigose esperada e observada, riqueza alélica, valor do Pic (conteúdo de informação de polimorfismo) e verificação do equilíbrio de Hardy-Weinberg. Os locos analisados foram SPS115, BM1824, BM2113, BMS4049, TGLA122, ETH225, ETH10, INRA23, UWCA46 e BMS348, identificando-se um total de 101 alelos, diversidade gênica média de 75,6\%, com valores extremos verificados nos locos TGLA122 (91,3\%) e $\operatorname{BMS4049}(45,4 \%)$. O valor médio da heterozigose esperada foi 75,5\%, observada 
60,0\%, e Pic 72,3\%. O coeficiente de endogamia Fis foi estatisticamente significativo (Fis=0,206; $\mathrm{P}<0,01$. Foram observados também desvios do equilíbrio de HardyWeinberg em todos os locos analisados. A partir dos dados obtidos foi possível observar que ainda existe diversidade genética nesta população, porém os desvios do equilíbrio, o valor significativo do Fis, e a heterozigose observada menor em todos os locos em relação à esperada demostraram a ocorrência de cruzamentos endogâmicos e homozigose nesta população. Assim sendo, a conservação deste patrimônio genético é de fundamental importância não só sob o ponto de vista científico e biológico, como também sob o ponto de vista cultural, histórico e econômico, uma vez que ela, por mais de 400 anos, faz parte da história do Brasil.

Termos para indexação: Pé-duro, Curraleiro, Bos taurus, microssatélites, caracterização genética, conservação.

\title{
“Genetic characterization of a Pé-duro native cattle herd using microsatellites.”
}

\author{
Abstract \\ The Pé-duro creole breed is adapted to the unfavorable environmental \\ conditions of the semi-arid zone of Northeastern Brazil and it is in extinction danger. \\ The objective of this work was the genetic characterization of a sample of Bos taurus, \\ Pé-duro breed ( $n=126)$, from the Unit of Conservation of Animal Genetic Resources of \\ Embrapa Meio-Norte, Piauí State, Northeastern Brazil, seeking the knowledge and the \\ conservation of this genetic patrimony. We examined heterozygosity, polymorphism \\ information content (Pic), allelic frequency and genetic diversity, inbreeding coefficient \\ and Hardy-Weinberg equilibrium, based on ten loci, SPS115, BM1824, BM2113, \\ BMS4049, TGLA122, ETH225, ETH10, INRA23, UWCA46 and BMS348. A total of 101
}


alleles were identified, the largest genetic diversity was verified in the locus TGLA122 (91,3\%), and the smallest in the locus BMS4049 (45,4\%). The mean expected heterozygosity was $75,5 \%$, the mean observed heterozygosity was $60,0 \%$, and the mean Pic value was estimated as $72,3 \%$. However we also observed a significant inbreeding coefficient (Fis) for this population (Fis $=0,206 \mathrm{P}<0,01$ ) and deviations from HardyWeinberg equilibrium in all analyzed loci. The genetic conservation of the Pé-duro breed is important because it constitutes a genetic patrimony adapted to the unfavorable environmental conditions of the semi-arid zone of Northeastern Brazil, and for more than 400 years it helped to write the history of this area.

Index terms: Pé-duro, Curraleiro, Bos taurus, microsatellites, genetic characterization, conservation.

\section{Introdução}

Os marcadores moleculares microssatélites são repetições curtas em tandem, com relativa abundância no genoma, apresentam alto grau de polimorfismo e têm sido muito utilizados em vários estudos sobre a diversidade genética dentro e entre populações de bovinos (MacHugh et al., 1997, 1998, Peelman et al., 1998, Kantanen et al., 2000, Beja-Pereira et al., 2003, Egito et al., 2004, Armstrong et al., 2006 e Barrera et al., 2006). Os locos microssatélites de acordo com a FAO Food and Agriculture Organization (1995, 2004) são os marcadores escolhidos para caracterização das raças e para projetos de conservação numa escala internacional, como o programa integrado de manejo dos recursos genéticos. A FAO através do projeto intitulado Measurement of Domestic Animal Diversity (MoDAD) (http://www.fao.org/dad_is), juntamente com a International Society of Animal Genetics (ISAG), em 1995, formou um grupo de 
consultores que elaboraram diretrizes e recomendações técnicas para a mensuração da diversidade genética. Uma lista de trinta locos de microssatélites selecionados foi elaborada para estudos de diversidade genética, caracterização das raças de bovinos e para projetos de conservação numa escala internacional, o que possibilita uma comparação objetiva devido à uniformização dos marcadores utilizados. No ano de 2004, foram incluídos novos marcadores microssatélites às listas recomendadas anteriormente.

A formação do gado crioulo ocorreu em todo o continente latino-americano, desde a época da colonização pelos portugueses e espanhóis (Armstrong et al., 2006). Durante séculos, esse gado esteve sob ação da seleção natural, permitindo sua adaptação ao ambiente particular de cada região, quase sem interferência do homem e se reproduzindo livremente (Primo, 1992, Mariante e Cavalcante, 2006), desenvolvendo assim características que permitiram sua sobrevivência em ambientes hostis, com baixa oferta de alimentos (Spritze et al., 2003). No continente sul-americano atualmente encontram-se várias raças, como o crioulo da Patagônia, na Argentina, o gado crioulo do Uruguai (Armstrong et al., 2006) e o gado crioulo colombiano (Barrera et al., 2006), entre outros. No Brasil, são exemplos de raças crioulas a Pantaneira, na região do Pantanal, a Crioula Lajeana, na região Sul, a Junqueira na região norte de São Paulo e no sul de Minas Gerais e a Pé-duro ou Curraleira, nos estados nordestinos e em Goiás e Tocantins (Mariante e Cavalcante, 2006).

Algumas raças crioulas vêm sendo caracterizadas geneticamente com microssatélites, visando contribuir para a sua conservação, como nos mostram Egito et al. (2004), com raças nativas brasileiras, Armstrong et al. (2006) com o gado crioulo do Uruguai e Barrera et al. (2006) com o gado crioulo colombiano. Uma revisão sobre a raça Pé-duro foi feita por Mariante e Cavalcante (2006). Carvalho et al. (2001) e 
Carvalho (2002) mostram aspectos de sua conservação e potencial econômico. Sob um ponto de vista mais específico, ela foi estudada citogeneticamente por Britto (1998), por meio de marcadores microssatélites por Egito et al. (2004), por Serrano et al. (2004) utilizando marcadores RAPD, e também foi incluída em estudos de filogeografia através do DNA mitocondrial (Miretti et al., 2004).

A raça Pé-duro é descendente dos bovinos trazidos pelos portugueses no período colonial. Esses animais, ao longo dos séculos, adaptaram-se gradualmente à seca, ao calor, a pastagens de inferior qualidade, a parasitas e a outros fatores adversos existentes na zona semi-árida nordestina, dando origem à atual raça Pé-duro. Seu porte, no entanto, tornou-se pequeno, o que reduziu seu valor econômico ( Carvalho, 2002).

Com a introdução das raças zebuínas no Brasil, de maior tamanho, os reprodutores da raça Pé-duro passaram a ser castrados sistematicamente e substituídos por touros zebus. Esse tipo de cruzamento absorvente quase extinguiu a raça Pé-duro (Carvalho,1985)

Visando contribuir para a manutenção deste valioso recurso genético, o atual Centro de Pesquisa Agropecuária do Meio-Norte (Embrapa Meio-Norte) estabeleceu em 1983, no município de São João do Piauí, PI, um rebanho para a conservação da raça Pé-duro. Este rebanho vem sendo de fundamental importância para esta tarefa.

Segundo levantamento do Ministério da Agricultura, existem no Nordeste, cerca de 154.117.00 hectares de superfície, correspondendo a 30,97\% ou de 47.725 .408 hectares do território regional de terras do grupo 5 de aptidão agrícola. Os bovinos da raça Pé-duro e seus mestiços constituem uma opção para o uso sustentável dessas terras do grupo 5 de aptidão agrícola no Nordeste Brasileiro. Essas terras são caracterizadas pelo sistema de manejo de nível baixo e/ou médio de insumos, e não são recomendadas para uso com lavouras ou pastagens cultivadas e sim como pastagens naturais 
(Carvalho, 2002). Por outro lado, com a crescente demanda mundial por produtos orgânicos, assim como o incremento do turismo no Nordeste, a raça Pé-duro poderá fornecer carne e laticínios de apelo regional.

O presente trabalho utilizou uma amostra coletada no Nordeste do Brasil, na tentativa de caracterizar geneticamente a raça Pé-duro com marcadores microssatélites, estimando sua variabilidade genética através de freqüências gênicas, diversidade gênica, heterozigose, conteúdo de informação de polimorfismo (Pic), além de verificar se a população está em equilíbrio de Hardy-Weinberg.

\section{Material e Métodos}

As amostras de DNA genômico foram obtidas a partir de sangue coletado em um rebanho do estado do Piauí $(\mathrm{n}=126)$, mantido na Fazenda Experimental Octavio Domingues, da Embrapa Meio-Norte, no município de São João do Piauí, PI.

Foram analisados dez microssatélites, SPS115, BM1824, BM2113, BMS4049, TGLA122, ETH225, ETH10, INRA23, UWCA46 e BMS348 (Tab. 1). Todas as seqüências analisadas, exceto as seqüências $B M S 4049$, $U W C A 46$ e $B M S 348$ fazem parte das 30 seqüências recomendadas pela FAO Food and Agriculture Organization e ISAG International Society of Animal Genetics para uso no estudo de diversidade genética de bovinos.

As amplificações por PCR foram realizadas com 200 ng de DNA genômico, 1,5 $\mathrm{mM}$ a 4,0 mM de $\mathrm{MgCl}_{2}, 200 \mu \mathrm{M}$ de cada dNTP, 0,150 $\mu \mathrm{M}$ a 0,200 $\mu \mathrm{M}$ para os iniciadores microssatélites, $2,5 \mu \mathrm{l}$ de tampão de reação fornecido com a enzima para a concentração de 10X, 1U/ $\mu \mathrm{l}$ de Taq polimerase (Biotools), e água desionizada para completar o volume final até $25 \mu \mathrm{l}$ (Tab. 2). A mistura total da PCR foi submetida ao 
termociclador modelo Robocycler 40 marca Stratagene, utilizando diferentes programas para cada loco (Tab. 3).

Os produtos amplificados foram analisados por eletroforese em géis de poliacrilamida 12\% desnaturante (uréia) e 10\% não desnaturante (glicerol), seguida de coloração com nitrato de prata de acordo com o protocolo de Sanguinetti et al. (1994). Os alelos foram identificados por ordem crescente de tamanho, definida pela migração eletroforética verificada na fonte Amershan Pharmacia Biotech (EPS 1001), ajustada à voltagem ou corrente constante necessária para uma boa separação dos fragmentos amplificados. A estimativa do tamanho em pares de base (bp) no gel desnaturante e não desnaturante foi verificada utilizando-se o marcador molecular DNA Ladder Invitrogen de peso molecular de 25pb e 50pb. Os alelos encontrados foram comparados entre si e, após uma leitura prévia, aquelas amostras que a princípio pareciam conter o mesmo alelo, foram comparadas lado a lado em outro gel, para confirmação de suas leituras. Após a corroboração foram escolhidos padrões precisos de leitura para tipagem das demais amostras.

As freqüências alélicas de cada loco foram estimadas por contagem direta na população Pé-duro, pelo programa GENEPOP, versão 3.0 (Raymond \& Rousset, 1995) e utilizadas para calcular a aderência ao equilíbrio de Hardy-Weinberg. O programa GDA, versão 1.0 (Lewis e Zaykin, 1997), foi empregado para estimar as heterozigoses esperada, observada e média, e a estatística F pela análise do Fis (coeficiente de endogamia), de acordo com a fórmula desenvolvida por Nei (1987); os valores de diversidade gênica e riqueza alélica foram calculados pelo programa FSTAT, versão 2.9.3 (Goudet, 2001), e os valores de Pic (conteúdo de informação de polimorfismo) para cada marcador microssatélite foram calculados pelo programa Cervus, versão 3.0.3 (Marshall et al., 1998). 


\section{Resultados e Discussão}

As freqüências alélicas calculadas para cada loco mostraram que os alelos mais freqüentes foram BMS4049*3 (71,8\%) e BMS348*2 (59,6\%) e todos os locos apresentaram baixa freqüência de muitos alelos $(<0,100)$ e uma alta freqüência de poucos alelos/loco como pode ser verificado na Tab. 3. Foi identificado um total de 101 alelos, com um número médio de 10,1 alelos por loco, enquanto que na população crioula da Colômbia estudada por Barrera et al., (2006), foi encontrado um valor médio de 5,5 alelos. O número de alelos por loco em Pé-duro está de acordo com os parâmetros de diversidade recomendados pela FAO, a qual sugere pelo menos cinco alelos por loco para ser considerado um bom indicador de variabilidade genética (Tab. 4).

A população Pé-duro apresentou um significativo valor médio de diversidade gênica, de 75,6\%. No trabalho de Barrera et al., (2006) com a raça crioula Romosinuana da Colômbia, foi encontrado um valor menor (59\%). Observamos também que os resultados aqui obtidos com microssatélites foram mais informativos para estudos de diversidade gênica, uma vez que contrastam com o valor obtido de 24,9\% por Serrano et al (2004), utilizando RAPD. Valores expressivos de diversidade gênica foram também observados em cada um dos locos analisados, sendo o maior valor de 91,2\% em $T G L A 122$, com o maior número de alelos (20 no total). O loco BM1824 apresentou também um valor significativo de diversidade gênica (76,4\%), próximo aos valores de heterozigose esperada $(76,4 \%)$ e observada $(76,2 \%)$ para este loco; entretanto o menor valor de diversidade gênica foi de 45,5\% no loco BMS4049 (Tab. 5).

Na população Pé-duro foram verificados valores menores de heterozigose observada em relação à esperada em todos os locos analisados em indicando, portanto, perda de variação genética ao longo do tempo e deficiência de heterozigotos, 
possivelmente ao isolamento da raça e ocorrência de endocruzamentos. O valor médio de heterozigose esperada foi de 75,5\%, semelhante aos 70,0\% encontrados por Egito et al. (2004), enquanto que o valor médio de heterozigose observada foi 60,0\% (Tab. 5) valor menor que os $64,5 \%$ observados por estes autores. Este fato observado em Péduro pode indicar uma deficiência de heterozigotos nesta população, que foi verificada também na análise do teste específico de déficit de heterozigotos de Hardy-Weinberg (Tab. 6). Barrera et al., (2006), analisando 12 locos na raça crioula Romosinuana da Colômbia, obtiveram valores de 78,0\% de heterozigose esperada e 59,0\% de heterozigose observada, próximos aos observados no presente trabalho.

As análises realizadas com os marcadores microssatélites revelaram desvios significativos do equilíbrio de Hardy-Weinberg $(\mathrm{p}<0,05)$ em todos os locos analisados no teste exato, com exceção do loco BMS348 (Tabela 6). Foram aplicados dois testes mais sensíveis do que o teste exato, para averiguar se o desvio é causado por déficit ou excesso de heterozigotos. Estes testes indicaram desvios significativos do equilíbrio de Hardy-Weinberg $(\mathrm{p}<0,05)$ devido à falta de heterozigotos em sete dos dez locos analisados, SPS115, BM2113, TGLA122, ETH225, ETH10, INRA23 e UWCA46 (Tabela 6). Este resultado do desvio do equilíbrio é condizente com os resultados observados em raças geneticamente isoladas e estruturadas, tais como, os de BejaPereira et al., (2003) com 15 raças ibéricas de bovinos de Portugal e Espanha e os de Egito et al., (2004). O desvio do equilíbrio afetando todos os locos pode sugerir a ocorrência de uma série de eventos não excludentes como acasalamentos endogâmicos, isolamento geográfico da população devido à subdivisão da raça, efeito dos fundadores ou deriva genética.

Confirmando este desvio do equilíbrio, o valor do coeficiente de endogamia Fis observado na população pé-duro, considerando todos os locos, foi estatisticamente 
significativo (Fis=0,206; $\mathrm{P}<0,01$ ), com o menor valor observado no loco BM1824, com 0,002 e o maior valor em ETH225, com 0,390 (Tab. 5). Barrera et al. (2006) também observaram um valor significativo de Fis $(0,25)$ na raça crioula Romosinuana da Colômbia. Ambas são raças isoladas geograficamente que sofreram diminuição de sua população ao longo dos anos e por isso são raças que estão inscritas em programas de conservação (Barrera et al., 2006). Com determinadas práticas de criação e de melhoramento genético, praticamente todas as populações de bovinos sofreram e ainda sofrem pressões seletivas. Estas pressões podem conferir altas taxas de endogamia, as quais podem contribuir para extinguir a população, ou para aumentar sua suscetibilidade a infecções e doenças (Keller e Waller, 2002).

As análises realizadas com os microssatélites também revelaram que o valor médio de Pic na população Pé-duro é de 70,3\% e está mais próximo do valor observado nas raças crioula lageana $(69,8 \%)$ e pantaneira $(70,8 \%)$ do que o valor de Pic de 65\% nesta mesma raça, no trabalho de Egito et al., (2004).

De uma maneira geral foram observados valores significativos de Pic em todos os locos analisados no presente trabalho, com um valor maior em TGLA122, 90,2\% e UWCA46, 90,1\%, (Tab. 5), indicando assim alta diversidade e polimorfismo, uma vez que valores de Pic maiores que 0,50 são considerados mais informativos. Foram observados também 13 locos informativos no trabalho de Armstrong et al., (2006), num total de 17 locos microssatélites analisados no gado crioulo do Uruguai. Somente o loco BM2113 analisado por estes autores é coincidente com o presente trabalho, com o valor de 73,9\% em Pé-duro e 75\% no gado crioulo do Uruguai. No trabalho de Cervini et al., (2006), que analisaram 10 microssatélites na raça comercial nelore foram verificados valores menores de Pic nos locos TGLA122, ETH225, ETH10, BM2113, BM1824 e INRA23, quando comparados aos valores obtidos em Pé-duro. De acordo com Cervini et 
al., (2006), esta diferença em variabilidade para alguns locos é devida ao fato de serem altamente informativos em Bos taurus, mas menos informativos em B. indicus.

Embora, tanto o valor do coeficiente de endogamia estatisticamente significativo, como os resultados obtidos do desvio do equilíbrio de Hardy-Weinberg possam nos dar uma inferência sobre homozigose na população pé-duro, foi possível verificar que ainda existe uma alta diversidade genética nesta raça nativa brasileira, evidenciada pelos valores obtidos nos índices de diversidade, tais como diversidade gênica, heterozigose esperada.

\section{Conclusões}

Tanto o valor do coeficiente de endogamia estatisticamente significativo, como os resultados obtidos dos baixos valores de heterozigose observada, baixa freqüência dos alelos e desvios do equilíbrio de Hardy-Weinberg possam nos dar uma inferência sobre homozigose na população Pé-duro, foi possível verificar que ainda existe uma diversidade genética nesta raça nativa brasileira. Diversidade que foi evidenciada pelos valores obtidos nos índices de diversidade, tais como diversidade gênica e heterozigose esperada. Certamente esta diversidade poderá ser perdida nas próximas gerações se programas de conservação não estiverem inseridos nessa realidade evidenciada pelo presente estudo. A criação de vários núcleos de conservação que possibilitariam a ocorrência de acasalamentos assistidos e a criação de bancos de germoplasma animal são ações de fundamental importância para criar condições eficazes para a conservação desta raça histórica do Brasil. 


\section{Agradecimentos}

Ao Conselho Nacional de Desenvolvimento Científico e Tecnológico pelo suporte financeiro e pela bolsa concedida para o desenvolvimento do trabalho. A Dra. Cláudia E. Vieira Wiezel e ao Dr. Eddy José Francisco de Oliveira pelas valiosas sugestões, a Elisabete Barreto Beira pela assistência técnica.

\section{Referências Bibliográficas}

ARMSTRONG, E.; POSTIGLIONI, A.; MARTÍNEZ, A.; RINCÓN, G. e VEGA-PLA, J. L. Microsatellite analysis of a sample of Uruguayan Creole bulls (Bos taurus). Gen. Mol. Biol. v. 29 (2): p. 267 - 272, 2006.

BARRERA, P.G.; MARINEZ, R.; PEREZ E.J.; POLANCO, N. e ARIZA, F. Evaluación de la variabilidad genética em ganado Criollo Colombiano mediante 12 marcadores microssatélites. Anim. Gen. Resources Inform. v. 38: p. 35 - 45, 2006.

BEJA-PEREIRA, A.; ALEXANDRINO, P.; BESSA, I.; CARRETERO, Y.; DUNNER, S.; FERRAND, N.; JORDANA, J.; LALOE, D.; MOAZAMI-GOUDARZI, K.; SANCHEZ, A. e CÂNON, J. Genetic characterization of southwestern European bovine breeds: A historical and biogeographical reassessment with a set of 16 microsatellites. J. Hered. v. 94 (3): p. 243 - 250, 2003.

BISHOP, M.D.; KAPPES, S.M.; KEELE, J.W.; STONE, R.T.; SUNDEN, S.L.F.; HAWKINS, G.A.; TOLDO, S.S.; FRIES, R.; GROSZ, M.D.; YOO, J. e BEATTIE, C.W. A genetic linkage map for cattle. Genetics v. 136: p. 619-639, 1994. 
CARVALHO, J.H. Pé-duro, patrimônio preservado no Piaú. Dirigente Rural, São Paulo, v. 24: p. 26 - 8, 1985.

CARVAlHO, J. H.; MONTEIRO, F.C.; GIRÃO,R.N. Conservação do bovino Pé-duro ou curraleiro: situação atual. Teresina: Embrapa Meio-Norte, 2001. 16 p. (Embrapa Meio-Norte. Documentos, 58).

CARVAlHO, J.H. Potencial econômico do bovino pé-duro. Teresina: Embrapa Meio-Norte, 2002. 14 p. (Embrapa Meio-Norte. Documentos, 65).

CERVINI, M.; HENRIQUE-SILVA, F.; MORTARI, N.E. e Jr. MATHEUCCI E. Genetic variability of 10 microsatellite markers in the characterization of Brazilian Nellore catlle (Bos indicus). Gen. Mol. Biol. v. 29 (3): p. 486 - 490, 2006

EGITO, A.A.; MARIANTE, A.S. e ALBURQUERQUE, M.S.M. Programa brasileiro de conservação de recursos genéticos animais. Arch. Zootec. v.51: p. 39 - 52, 2002.

EGITO, A.A.; PAIVA, S.R.; MAMANÍ, E.M.; ALBUQUERQUE, M.S.M.; MCNAMUS, C.; CASTRO, S.; MARIANTE, A.S. e GRATTAPAGLIA, D. Variabilidade genética de raças bovinas baseada em marcadores STR. In: V Simpósio da Sociedade Brasileira de Melhoramento Animal, 2004, Pirassununga-SP, 8 e 9 de julho. 
FAO, FOOD AND AGRICULTURE ORGANIZATION OF THE UNITED NATIONS. Global Project for the Maintenance of Domestic Animal Genetic Diversity. 2004. Disponível em: <http://www.fao.org/dad-is/>. Acesso em 2005.

FRIES, R.; EGGEN, A. e WOMACK, J.E. The bovine map. Mamm. Genome v. 4: p. $405-428,1993$.

GOUDET, J. A program to estimate and test gene diversities and fixation indices FSTAT (version 2.9.3). 2001.

KANTANEN, J.; OLSAKER I.; HOLM, L.-E.; LIEN, S.; VILKKI, J.; BRUSGAARD, K.; EYTHORSDOTTIR, E.; DANELL, B. e ADALSTEINSSON, S. Genetic diversity and population structure of 20 North European catlle breeds. J. Hered. v. 91: (6): p. 446 - 457, 2000.

KELLER, L.K. e WALLER, D.M. Inbreeding effects in wild populations. Trends Ecol. Evol. v. 17(5): p. 230 - 241, 2002.

LARA, M.A.C.; CONTEL, E.P.B. e SERENO J.R.B. Caracterización genética de poblaciones cebuínas através de marcadores moleculares. Arch. Zootec. v. 54: p. $295-303,2005$.

LEWIS, P.O. e ZAYKIN, D. Genetic data analysis: software for the analysis of discrete genetic data. Version 1.0. 1997. 
MACHUGH, D.E.; SHIVER, M.D.; LOFTUS, R.T.; CUNNINGHAM, P. e BRADLEY, D.G. Microsatellite DNA variation and the evolution, domestication and phylogeography of taurine and zebu catlle (Bos taurus and Bos indicus). Genetics v. 146: (3): p. 1071 - 1086, 1997.

MACHUGH, D.E.; LOFTUS, R.T.; CUNNINGHAM, P. e BRADLEY, D.G. Genetic structure of seven European catlle breeds assessed using 20 microsatellites markers. Anim. Genet. v. 29: p. 333 - 340, 1998.

MARIANTE, A.S. e CAVALCANTE, N. Animais do descobrimento: raças domésticas da história do Brasil. Brasília, DF, 2ª ed., EMBRAPA, 2006. 274p.

MARSHALL, T.C.; SLATE, J.; KRUUK, L.E.B. e PEMBERTON, J.M. Statistical confidence for likelihood-based paternity inference in natural populations. Molec. Ecol. v. 7: p. 639-655, 1998.

MAUDET, C.; LUIKART, G. e TABERLET, P. Genetic diversity and assignment tests among seven French catlle breeds based on microsatellites DNA analysis. J. Anim. Sci. v. 80: p. 942 - 949, 2002.

MIRETTI, M.M.; DUNNER, S.; NAVES, M.; CONTEL, E.P. e FERRO, J. A. African derived mtDNA in Spanish cattle (Bos taurus) is identical to the predominant African - derived mtDNA haplotype in Caribbean and Brazilian Creole cattle. J. Hered. v. 95: p. $450-453,2004$. 
NEI, M. Molecular Evolutionary Genetics. Columbia University Press, New York, 1987. 512p.

PEELMAN, L.J.; MORTIAUX, F.; ZEVERAN, A.V.; DANSERCOER, A.; MOMMERS, G.; COOPMAN, F.; BOUQUET, Y.; BURNY, A.; RENAVILLE, R. e PORTELLE, D. Evaluation of the genetic variability of 23 bovine microsatellite markers in four Belgian catlle breeds. Anim. Genet. v. 29: p. 161 - 167, 1998.

PRIMO, A.T. El ganado bovino ibérico em las Américas: 500 años después. Arch. Zootec. v. 41: p. 421 - 432, 1992.

RAYMOND, M. e ROUSSET, F. GENEPOP (version 2.0): population genetics software for exact tests and ecumenicism. J. Hered. v. 86: p. 248 - 249, 1995.

SERRANO, G.M.; EGITO, A.A.; MCMANUS, C. e MARIANTE, A.S. Genetic diversity and population structure of Brazilian native bovine breeds. Pesq. Agropec. Bras. v. 39 (6): p. 543 - 549, 2004.

SPRITZE, A.; EGITO, A.A.; MARIANTE, A.S. e MCMANUS, C. Genetic characterization of Criollo Lageano cattle by RAPD markers. Pesq. Agropec. Bras. v. 38 (10): p. 1157 - 1164, 2003.

STONE, R.S.; KAPPES, S.M. e BEATTIE, C.W. Five polymorphic trinucleotide (CCA) bovine microsatellites. Anim. Genet. v. 27 (3): p. 216, 1996 
Tabela 1 - Marcadores microssatélites, localização cromossômica (Cr.), Seqüência do primer e tamanho dos fragmentos descritos (pb) para os dez locos analisados.

\begin{tabular}{|c|c|c|c|c|}
\hline $\begin{array}{l}\text { Marcadores } \\
\text { microssatélites }\end{array}$ & Cr. & $\begin{array}{c}\text { Seqüência do primer } \\
\text { (5' -> 3') Forward } \\
\text { Reverse }\end{array}$ & $\begin{array}{l}\text { Tamanho } \\
\text { (bp) }\end{array}$ & Referência \\
\hline SPS115 & 15 & $\begin{array}{l}\text { AAAGTGACACAACAGCTTCTCCAG } \\
\text { AACGAGTGTCCTAGTTTGGCTGTG }\end{array}$ & $234-258$ & Peelman et al. (1998) \\
\hline BM1824 & 1 & $\begin{array}{l}\text { GAGCAAGGTGTTTTTCCAATC } \\
\text { CATTCTCCAACTGCTTCCTTG }\end{array}$ & $176-197$ & Bishop et al, (1994) \\
\hline BM2113 & 2 & $\begin{array}{l}\text { GCTGCCTTCTACCAAATACCC } \\
\text { CTTCCTGAGAGAAGCAACACC }\end{array}$ & $122-156$ & $\begin{array}{l}\text { Maudet et al, (2002) } \\
\text { Peelman et al, (1998) }\end{array}$ \\
\hline BMS4049 & 1 & $\begin{array}{l}\text { GATCAAGTTGTCAACACACACAC } \\
\text { TCTCATTTCTCTCCCTGTGC }\end{array}$ & $91-111$ & Stone et al. (1996) \\
\hline TGLA122 & 21 & $\begin{array}{l}\text { CCCTCCTCCAGGTAAATCAGC } \\
\text { AATCACATGGCAAATAAGTACATAC }\end{array}$ & $136-184$ & $\begin{array}{l}\text { Maudet et al, (2002) } \\
\text { Peelman et al, (1998) }\end{array}$ \\
\hline ЕTH225 & 9 & $\begin{array}{l}\text { GATCACCTTGCCACTATTTCCT } \\
\text { ACATGACAGCCAGCTGCTACT }\end{array}$ & 131-159 & Fries et al, (1993) \\
\hline ETH10 & 5 & $\begin{array}{l}\text { GTTCAGGACTGGCCCTGCTAACA } \\
\text { CCTCCAGCCCACTTTCTCTTCTC }\end{array}$ & $207-231$ & $\begin{array}{l}\text { Steffen et al (1993) } \\
\text { Vaiman et al (1994) }\end{array}$ \\
\hline INRA23 & 3 & $\begin{array}{l}\text { GAGTAGAGCTACAAGATAAACTTC } \\
\text { TAACTACAGGGTGTTAGATGAACTC }\end{array}$ & $195-222$ & Vaiman et al (1994) \\
\hline UWCA46 & 1 & $\begin{array}{l}\text { CCATTTCTCTGTTGGTAACTGC } \\
\text { CTCTCACAGGTGGGGTC }\end{array}$ & $120-147$ & Sun et al, (1995) \\
\hline BMS348 & 14 & $\begin{array}{l}\text { TTTTATGTGCACCACCCG } \\
\text { ACTCACTGGCTCTCAATGACTC }\end{array}$ & 158-182 & Stone et al, (1995) \\
\hline
\end{tabular}


Tabela 2. Condições de PCR para uma reação dos microssatélites analisados: temperatura de pareamento na PCR $\left(\mathrm{Tm}^{0}\right)$, concentração de $\mathrm{MgCl}_{2}\left[\mathrm{MgCl}_{2}\right]$, concentração dos iniciadores microssatélites [STRs], concentração da solução dNTP e DNA polimerase (Taq): quantidade de $1 \mathrm{U} / \mu \mathrm{l}$.

\begin{tabular}{l|lllll}
\hline Microssatélites & $\begin{array}{l}\mathbf{T m}^{\mathbf{0}} \\
\left({ }^{\circ}\right)\end{array}$ & $\begin{array}{l}\left.\text { [MgCl }_{2}\right] \\
(m M)\end{array}$ & $\begin{array}{l}\text { [STRs] } \\
(\mu M)\end{array}$ & $\begin{array}{l}\text { dNTP } \\
(\mu M)\end{array}$ & $\begin{array}{l}\text { Taq DNA } \\
(U / \mu l)\end{array}$ \\
\hline SPS115 & $58-63^{\circ}$ & 1,5 & 0,175 & 200 & 0,5 \\
BM1824 & $58-63^{\circ}$ & 1,5 & 0,150 & 200 & 0,5 \\
BM2113 & $58-63^{\circ}$ & 1,5 & 0,175 & 200 & 0,5 \\
BMS4049 & $55^{\circ}$ & 3,0 & 0,150 & 200 & 0,5 \\
TGLA122 & $45^{\circ}$ & 3,0 & 0,180 & 200 & 0,5 \\
ETH225 & $57^{\circ}$ & 3,0 & 0,150 & 200 & 0,5 \\
ETH10 & $55^{\circ}$ & 3,0 & 0,100 & 200 & 0,5 \\
INRA23 & $50^{\circ}$ & 4,0 & 0,200 & 200 & 0,5 \\
UWCA46 & $57^{\circ}$ & 4,0 & 0,150 & 200 & 0,3 \\
BMS348 & $58^{\circ}$ & 4,0 & 0,150 & 200 & 0,3 \\
\hline
\end{tabular}


Tabela 3. Programas utilizados para amplificação dos locos microssatélites.

\begin{tabular}{|c|c|c|c|c|c|c|c|}
\hline \multicolumn{8}{|c|}{ Locos } \\
\hline $\begin{array}{l}B M 1824 \\
B M 2113 \\
\end{array}$ & BMS4049 & TGLA 122 & ЕTH225 & ЕТН10 & INRA23 & UWCA46 & BMS348 \\
\hline $\begin{array}{l}1 \text { ciclo: } \\
94^{\circ} \mathrm{C}-5\end{array}$ & $\begin{array}{l}1 \text { ciclo: } \\
94^{\circ} \mathrm{C}-1\end{array}$ & $\begin{array}{c}1 \text { ciclo: } \\
95^{\circ} \mathrm{C}-10\end{array}$ & $\begin{array}{l}1 \text { ciclo: } \\
94^{\circ} \mathrm{C}-1\end{array}$ & $\begin{array}{l}1 \text { ciclo: } \\
94^{\circ} \mathrm{C}-1\end{array}$ & $\begin{array}{l}1 \text { ciclo: } \\
94^{\circ} \mathrm{C}-5\end{array}$ & $\begin{array}{l}1 \text { ciclo: } \\
94^{\circ} \mathrm{C}-5\end{array}$ & $\begin{array}{l}1 \text { ciclo: } \\
94^{\circ} \mathrm{C}-5\end{array}$ \\
\hline $\begin{array}{l}5 \text { ciclos: } \\
94^{\circ} \mathrm{C}-1 \\
63^{\circ} \mathrm{C}-1 \\
72^{\circ} \mathrm{C}-1\end{array}$ & - & - & - & - & - & - & - \\
\hline $\begin{array}{l}30 \text { ciclos: } \\
94^{\circ} \mathrm{C}-1 \\
58^{\circ} \mathrm{C}-1 \\
72^{\circ} \mathrm{C}-1\end{array}$ & $\begin{array}{l}35 \text { ciclos: } \\
94^{\circ} \mathrm{C}-1 \\
55^{\circ} \mathrm{C}-1 \\
72^{\circ} \mathrm{C}-1\end{array}$ & $\begin{array}{c}35 \text { ciclos: } \\
95^{\circ} \mathrm{C}-30^{\circ} \\
45^{\circ} \mathrm{C}-1 \\
72^{\circ} \mathrm{C}-1\end{array}$ & $\begin{array}{l}35 \text { ciclos: } \\
94^{\circ} \mathrm{C}-1 \\
57^{\circ} \mathrm{C}-1 \\
72^{\circ} \mathrm{C}-1\end{array}$ & $\begin{array}{l}38 \text { ciclos: } \\
94^{\circ} \mathrm{C}-1 \\
55^{\circ} \mathrm{C}-1 \\
72^{\circ} \mathrm{C}-1\end{array}$ & $\begin{array}{c}32 \text { ciclos: } \\
94^{\circ} \mathrm{C}-40^{\circ} \\
50^{\circ} \mathrm{C}-1 \\
72^{\circ} \mathrm{C}-1\end{array}$ & $\begin{array}{c}32 \text { ciclos: } \\
94^{\circ} \mathrm{C}-40^{\circ} \\
57^{\circ} \mathrm{C}-1 \\
72^{\circ} \mathrm{C}-1\end{array}$ & $\begin{array}{c}32 \text { ciclos; } \\
94^{\circ} \mathrm{C}-40 \\
58^{\circ} \mathrm{C}-1 \\
72^{\circ} \mathrm{C}-1\end{array}$ \\
\hline $\begin{array}{c}1 \text { ciclo: } \\
72^{\circ} \mathrm{C}-10\end{array}$ & $\begin{array}{c}1 \text { ciclo: } \\
72^{\circ} \mathrm{C}-10\end{array}$ & $\begin{array}{c}1 \text { ciclo: } \\
72^{\circ} \mathrm{C}-20\end{array}$ & $\begin{array}{c}1 \text { ciclo: } \\
72^{\circ} \mathrm{C}-20^{\prime}\end{array}$ & $\begin{array}{c}1 \text { ciclo: } \\
72^{\circ} \mathrm{C}-20^{\prime}\end{array}$ & $\begin{array}{c}1 \text { ciclo: } \\
72^{\circ} \mathrm{C}-10\end{array}$ & $\begin{array}{c}1 \text { ciclo: } \\
72^{\circ} \mathrm{C}-10\end{array}$ & $\begin{array}{c}1 \text { ciclo: } \\
72^{\circ} \mathrm{C}-10\end{array}$ \\
\hline
\end{tabular}


Tabela 4. Freqüências alélicas para os dez microssatélites analisados na população Pé-duro. Os alelos mais freqüentes (>20\%) aparecem destacados.

\begin{tabular}{|c|c|c|c|c|c|c|c|c|c|c|}
\hline Alelos & SPS115 & BM1824 & BM2113 & BMS4049 & TGLA122 & ЕTH225 & ЕТН10 & INRA23 & UWCA46 & BMS348 \\
\hline 2 & 0,516 & 0,316 & 0,105 & & & 0,004 & 0,096 & 0,024 & 0,020 & 0,596 \\
\hline 4 & 0,092 & 0,184 & 0,379 & 0,159 & & 0,063 & 0,072 & 0,060 & 0,087 & \\
\hline 5 & 0,136 & 0,086 & 0,153 & 0,044 & 0,012 & 0,210 & 0,200 & 0,052 & 0,095 & \\
\hline 6 & 0,080 & 0,008 & 0,024 & & & 0,075 & 0,164 & 0,077 & 0,040 & \\
\hline 9 & & & 0,012 & & 0,008 & 0,008 & 0,036 & 0,157 & 0,024 & \\
\hline 10 & & & & & 0,091 & 0,012 & 0,036 & 0,065 & 0,107 & \\
\hline 11 & & & & & 0,004 & 0,004 & 0,012 & 0,198 & 0,143 & \\
\hline 12 & & & & & & & 0,012 & 0,113 & 0,099 & \\
\hline
\end{tabular}




\begin{tabular}{|c|c|c|c|}
\hline 13 & 0,033 & 0,040 & 0,099 \\
\hline 14 & 0,021 & 0,008 & 0,024 \\
\hline 15 & 0,033 & 0,008 & \\
\hline 16 & 0,004 & & \\
\hline 17 & 0,008 & & \\
\hline 18 & 0,083 & & \\
\hline 19 & 0,058 & & \\
\hline 20 & 0,190 & & \\
\hline 21 & 0,037 & & \\
\hline 22 & 0,120 & & \\
\hline 23 & 0,045 & & \\
\hline 24 & 0,066 & & \\
\hline
\end{tabular}


Tabela 5. Heterozigose esperada (He), heterozigose observada (Ho), diversidade gênica (Hs), conteúdo de informação de polimorfismo (Pic) e valor do Fis para cada loco na população Pé-duro.

\begin{tabular}{l|ccccc}
\hline \multicolumn{1}{c|}{ Locos } & $\mathbf{( H e )}$ & $\mathbf{( H o )}$ & $\mathbf{( H s )}$ & Pic & Fis \\
\hline SPS115 & 0,687 & 0,576 & 0,688 & 0,657 & 0,162 \\
BM1824 & 0,764 & 0,762 & 0,764 & 0,722 & 0,002 \\
BM2113 & 0,772 & 0,621 & 0,772 & 0,739 & 0,195 \\
BMS4049 & 0,454 & 0,373 & 0,455 & 0,420 & 0,179 \\
TGLA122 & 0,912 & 0,661 & 0,913 & 0,902 & 0,275 \\
ETH225 & 0,780 & 0,476 & 0,781 & 0,745 & 0,390 \\
ETH10 & 0,880 & 0,672 & 0,880 & 0,864 & 0,237 \\
INRA23 & 0,896 & 0,596 & 0,898 & 0,884 & 0,334 \\
UWCA46 & 0,911 & 0,801 & 0,913 & 0,901 & 0,121 \\
BMS348 & 0,502 & 0,464 & 0,502 & 0,397 & 0,075 \\
\hline Valor médio & $\mathbf{0 , 7 5 5}$ & $\mathbf{0 , 6 0 0}$ & $\mathbf{0 , 7 5 6}$ & $\mathbf{0 , 7 2 3}$ & $\mathbf{0 , 2 0 6 *}$ \\
\hline
\end{tabular}

$* \mathrm{P}<0,01$ 
Tabela 6. Probabilidade obtida com o teste exato e déficit de heterozigotos para verificação do Equilíbrio de HardyWeinberg pelo método de Fisher para cada loco na população Pé-duro.

\begin{tabular}{l|ll}
\hline Locos & $\begin{array}{l}\text { Teste exato } \\
\text { Hardy-Weinberg } \\
\text { (valor de } P \text { ) }\end{array}$ & $\begin{array}{l}\text { Teste déficit de } \\
\text { heterozigotos } \\
\text { Hardy-Weinberg } \\
\text { (valor de } P \text { ) }\end{array}$ \\
\hline SPS115 & $0,0000^{*}$ & $0,0063^{*}$ \\
BM1824 & $0,0026^{*}$ & 0,1994 \\
BM2113 & $0,0000^{*}$ & $0,0029^{*}$ \\
BMS4049 & $0,0002^{*}$ & 0,0566 \\
TGLA122 & $0,0000^{*}$ & $0,0000^{*}$ \\
ETH225 & $0,0000^{*}$ & $0,0000^{*}$ \\
ETH10 & $0,0000^{*}$ & $0,0000^{*}$ \\
INRA23 & $0,0000^{*}$ & $0,0000^{*}$ \\
UWCA46 & $0,0000^{*}$ & $0,0003^{*}$ \\
BMS348 & 0,1206 & 0,2655 \\
\hline
\end{tabular}

*Desvio significativo $(\mathrm{P}<0,05)$. 